日萝理誌 $52,186 \sim 213(1956)$

\title{
Nicotine の䊿胎仔に及ぼす影響に就て
}

\author{
木 脇 彊 \\ (昭和医科大学薬理学教室〔主任 角尾滋教授〕) \\ (昭和医科大学病理学教室〔主任 渡辺五郎教授〕) \\ (昭和31年 1 月17日受付[特])
}

\section{緒言}

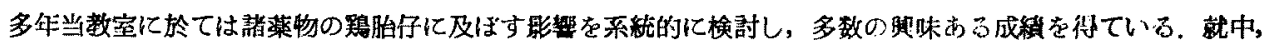

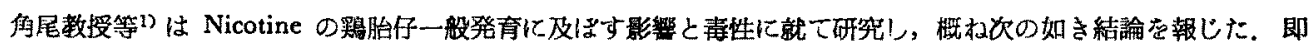

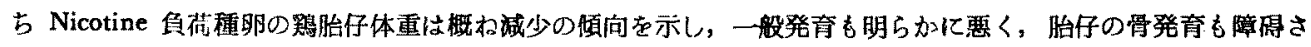

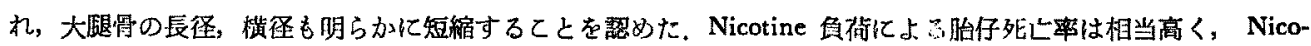
tine 注射量に比例して上昇し, Nicotine 2 3mg以上を負荷する掦合には多数の䗁型，特に水腫形成がみられる

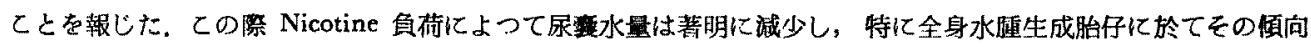

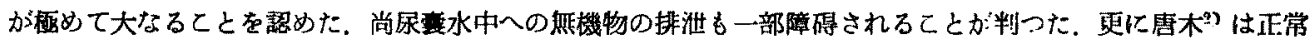

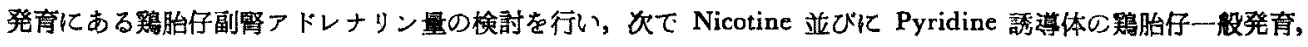

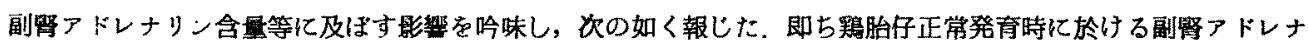
リン量は睬卵12日以後に於て明ら加に証明され，15日，18日目には更に増加するが， Nicotine (或は Nicotine tartrate）負荷は同時期に於ける副㹂アドレナリン量を更に著明に増加する，然し Pyridine 並びに Pyridine 誘 導体 (INAH, Nicotinic acid, Nicotinamide, Coramine) には Nicotine 程の作用はないか, 或住副留アドレナ リン量に対し殆ど影掣を及ばさないととを認めた。

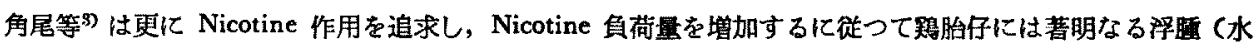

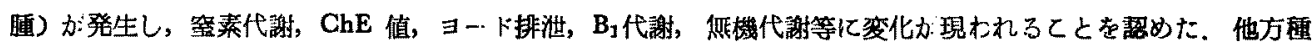
瞈内に於ける Nicotine の運命に就ても検討し, Nicotine が長期間に亘つて吸収, 排泄され，瞟眃日数の経過と

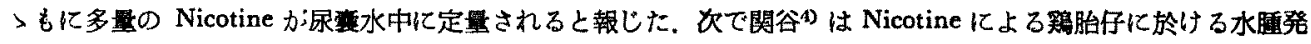

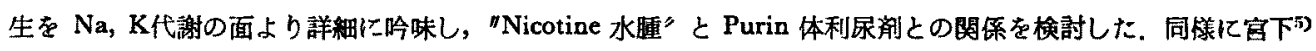

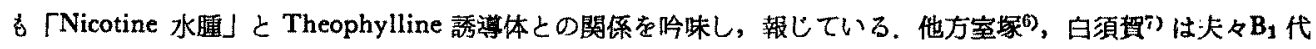

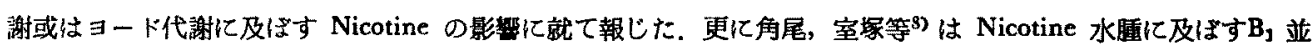

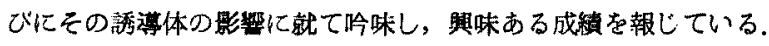

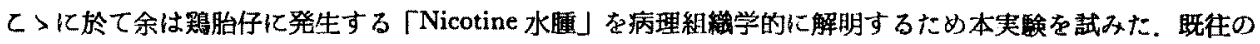

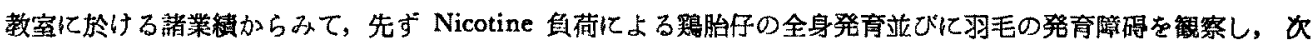

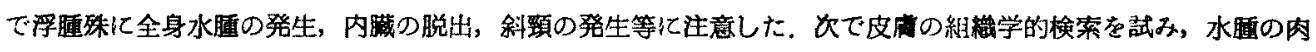

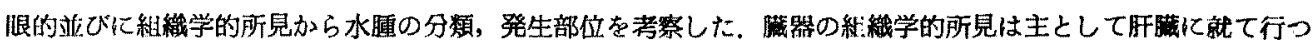
だ，水腫例に於てはその他䑏器をも追及した。

\section{実験材料並ひに方法}

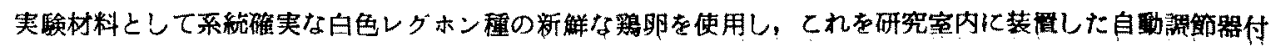

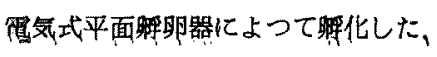




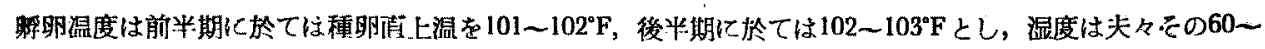

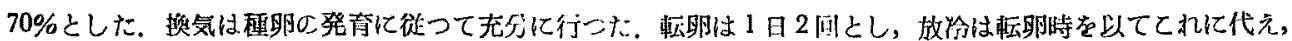

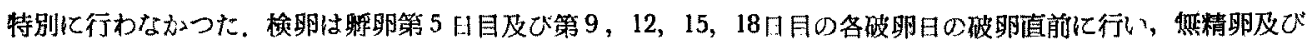

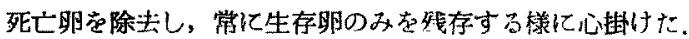

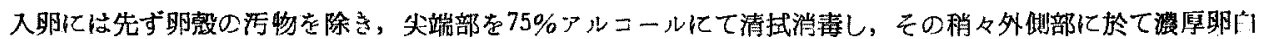

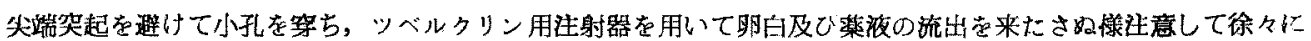

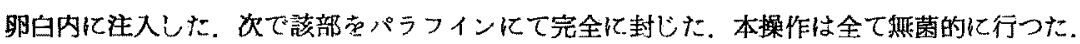

本実験に使用した Nicotine は Merck 及び Eastman-Kodak 製品にして，注射て祭しては0.Icc中に火々0.1 $\mathrm{mg}, 1.0 \mathrm{mg}, 2.0 \mathrm{mg}, 3.0 \mathrm{mg}, 4.0 \mathrm{mg}, 5.0 \mathrm{mg}$ 洽有される様に隇菌蒸溜水中に溶解して用いた，尚刘照として

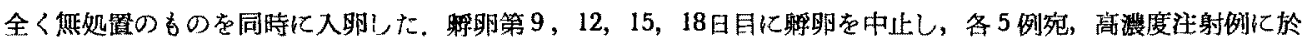

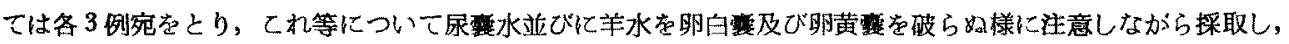
その総量及び胎仔体重を测定した。，次で有覆水及び羊水の $\mathrm{pH}$ を测定した，胎仔は型の如く10倍示ルマリン液に

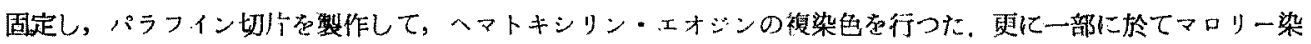

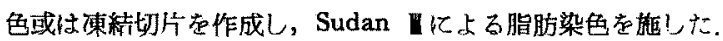

\section{実 験 成 績}

\section{A. 死亡率，胎任体重，尿霍水並びに羊水の变化}

1) 死亡率

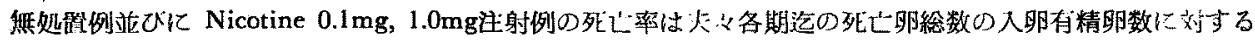

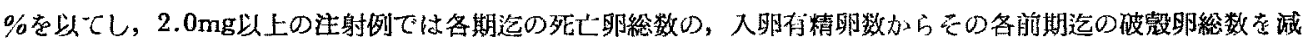
じたものに対ぢ\%以て表した。

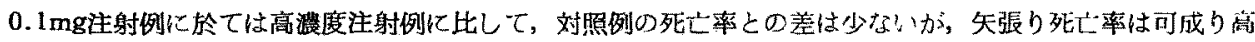

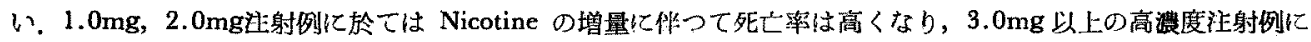

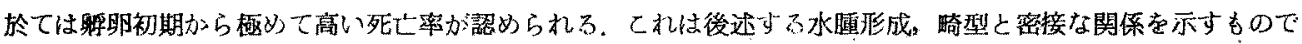

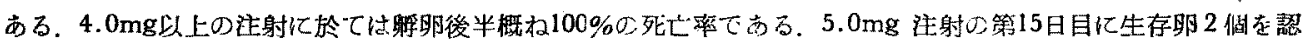

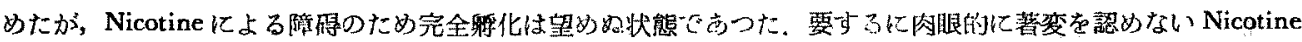
注射量は2.0mg前後と思才れる(第 1 表).

第 1 表. Nicotine 注射に上る践胎仔の死亡率。

\begin{tabular}{|c|c|c|c|c|c|c|c|c|c|c|c|c|c|c|c|c|c|c|c|c|c|}
\hline \multirow{2}{*}{$\begin{array}{c}\text { 注射量 } \\
(\mathrm{mg} / 0.1 \mathrm{cc})\end{array}$} & \multirow{2}{*}{$\begin{array}{l}\text { 入 } \\
\text { 卵 } \\
\text { 数 }\end{array}$} & \multirow{2}{*}{$\begin{array}{l}\text { 無 } \\
\text { 鈢 } \\
\text { 数 }\end{array}$} & \multirow{2}{*}{$\begin{array}{l}\text { 有 } \\
\text { 精 } \\
\text { 数 } \\
\text { 数 }\end{array}$} & \multicolumn{3}{|c|}{ 第 5 日目 } & \multicolumn{3}{|c|}{ 第 9 日 目 } & \multicolumn{4}{|c|}{ 第 12 H目 } & \multicolumn{4}{|c|}{ 第 15 日 目 } & \multicolumn{4}{|c|}{ 第 18 日 目 } \\
\hline & & & & \begin{tabular}{|l} 
生矂 \\
存数
\end{tabular} & $\begin{array}{l}\text { 死明 } \\
\text { L数 }\end{array}$ & \begin{tabular}{|l} 
死 \\
$亡$ \\
漈
\end{tabular} & 生率 & $\begin{array}{l}\text { 死明 } \\
\text { 亡数 }\end{array}$ & $\begin{array}{l}\text { 死総 } \\
\text { L } \\
\text { 罵数 }\end{array}$ & $\mid \begin{array}{ll}\text { 死 } & \text { 生㽗 } \\
\text { L } & \text { 存数 }\end{array}$ & \begin{tabular}{|l|} 
死盺 \\
亡数
\end{tabular} & $\begin{array}{l}\text { 死綉 } \\
L^{2} \\
\text { 挏数 }\end{array}$ & $\mid \begin{array}{c}\text { 死 } \\
亡 \\
\text { 乐 }\end{array}$ & \begin{tabular}{|l|} 
生卵 \\
存数
\end{tabular} & $\begin{array}{l}\text { 死明 } \\
\text { 亡数 }\end{array}$ & 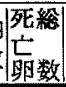 & $\begin{array}{l}\text { 死 } \\
\stackrel{亡}{亡} \\
\text { 率 }\end{array}$ & 生䀦 & \begin{tabular}{|l|} 
死㵊 \\
亡数
\end{tabular} & \begin{tabular}{|l|} 
死䋮 \\
亡 \\
数数 \\
\end{tabular} & $\begin{array}{l}\text { 死 } \\
\frac{L}{4}\end{array}$ \\
\hline 対 照 & 20 & 3 & 17 & 17 & 0 & 0 & $16(3)$ & 1 & 1 & $5.9_{1}^{\prime} 13(3)$ & 0 & 1 & 5.9 & $8(4)$ & 2 & 3 & 17.6 & 4 & 0 & 3 & 17.6 \\
\hline 0.1 & 29 & 0 & 29 & 28 & 1 & 3.5 & $26(6)$ & 2 & 3 & $13.518(2)$ & 2 & 5 & 17.2 & $15(5$ & 1 & 6 & 20.7 & 9 & 1 & 7 & 24.1 \\
\hline 1.0 & 29 & 1 & 28 & 22 & 6 & 21.4 & $22(6)$ & 0 & 6 & $21.414(4)$ & 2 & 8 & 28.6 & $10(4)$ & 0 & 8 & 28.6 & 6 & 0 & 8 & 28.6 \\
\hline 2.0 & 50 & 6 & 44 & 40 & 4 & 9.1 & $39(3)$ & 1 & 5 & $11.427(3)$ & 9 & 14 & 34.2 & $16(6)$ & 8 & 22 & 57.9 & 9 & 1 & 23 & 71.9 \\
\hline 3.0 & 40 & 6 & 34 & 21 & 13 & 38.2 & $16(3)$ & 5 & 18 & $52.911(1)$ & 2 & 20 & 64.5 & $5(1)$ & 5 & 25 & 83.3 & 1 & 3 & 28 & 96.5 \\
\hline 4.0 & 50 & 9 & 41 & 24 & 17 & 41.5 & $\mid 16(1)$ & 8 & 25 & $61.0) 9(3)$ & 6 & 31 & 77.5 & 0 & 6 & 37 & 100 & 0 & 0 & & \\
\hline 5.0 & 61 & 4 & 57 & 36 & 21 & 36.8 & $26(3)$ & 10 & 31 & $54.411(3)$ & 12 & 43 & 79,6 & $2(2)$ & 6 & 49 & 89.1 & 0 & 0 & & \\
\hline
\end{tabular}

2) 体重の変 化 (第 2 第 5 患)

体重は入卵時期立び㑑体差による変動が大きく，第 $9 ， 12 ， 15$ 日目迄は $0.1 \mathrm{mg}, 1.0 \mathrm{mg}, 2.0 \mathrm{mg}$ 注射例に

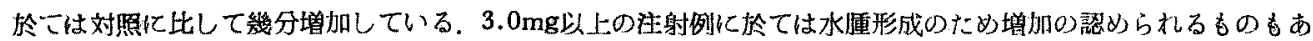

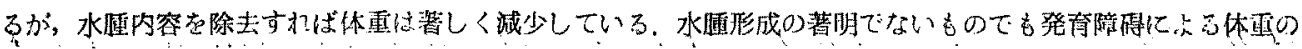




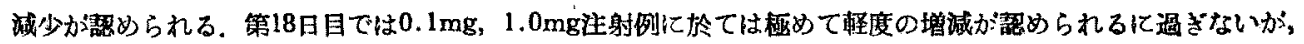
2.0mg以上の注射列では著明な体重の減少が認少られる。

\section{3) 尿霍水の变化（第 2 丰一第 5 表）}

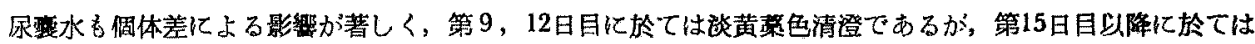

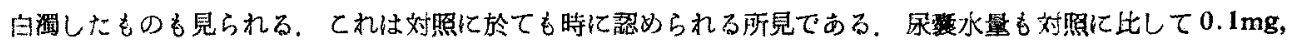

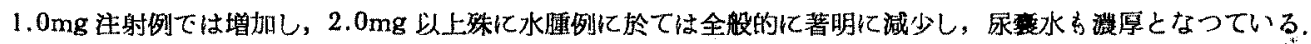

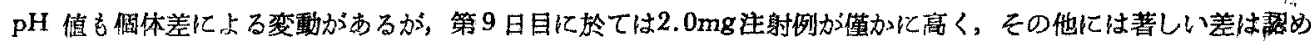
られない，第12日目に於ては対照及び0.1 $\mathrm{mg}, 1.0 \mathrm{mg}, 2.0 \mathrm{mg}$ 注射例では珰しい龵仗瑟められないか，3.0mg，

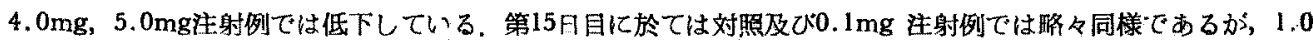

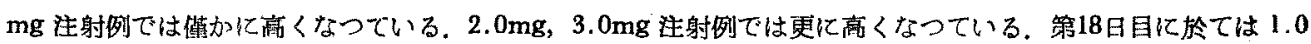

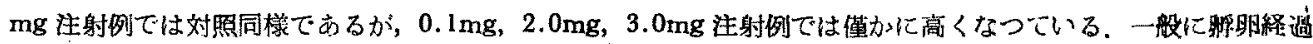

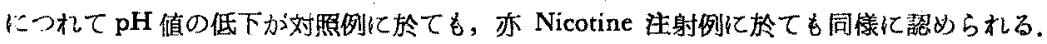

4) 羊水の変化 (第 2 表一第 5 蜜)

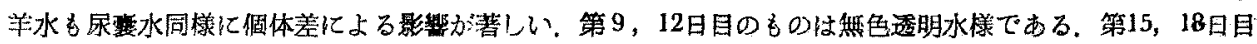

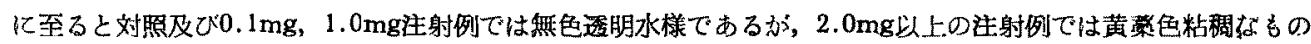

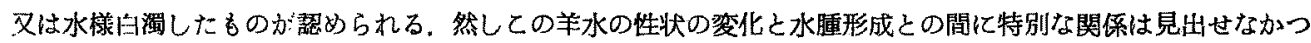

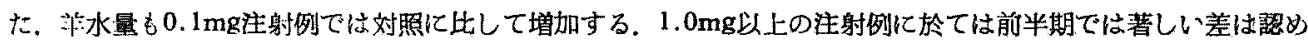
られないか，後半期殊に水腫例では全般的に減少している。 pH 值は第 9 日目に於て依 Nicotine 注射例では一

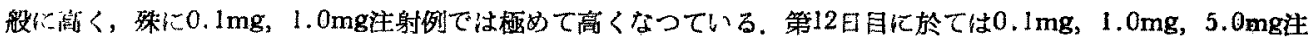
射例では明らかに高く、3.0mg，4.0mg注射例では前群に比して少るが矢張り高い，第15日目に於ては0.1.ang，

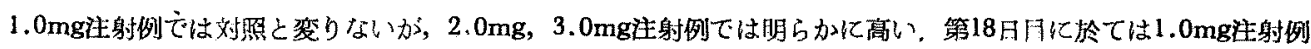

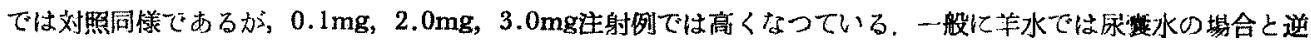
に能半期に比して後半期に於ては $\mathrm{pH}$ 值は高くなつている。

\section{B. 発育陼碍の肉眼的所見 (第 2 表一第 5 娄)}

1) 全身の発育陆碍

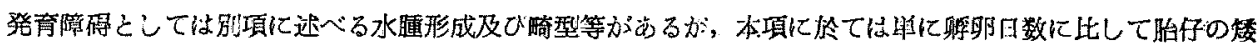

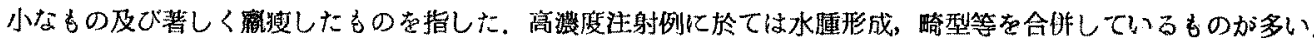

第9日目に於ては対照, $0.1 \mathrm{mg}, 1.0 \mathrm{mg}$ 注射例では見られないが, $2.0 \mathrm{mg}$ 注射例に揇度のものか3 3 例, 3.0

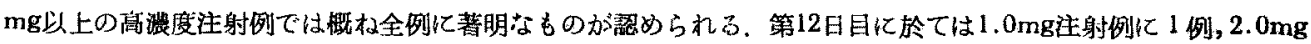

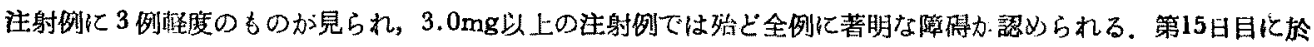
ては怪度のちのは $1.0 \mathrm{mg}$ 注射例及ひ2 $2.0 \mathrm{mg}$ 注射例に夫々 3 例, 高度のものは $2.0 \mathrm{mg}$ 注射例に 2 例, $3.0 \mathrm{mg}, 4.0$

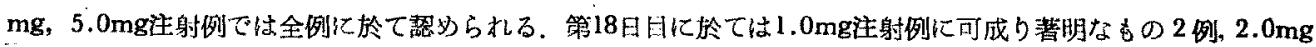

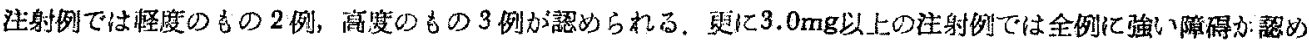
られる。

2) 羽毛の発育倩碍

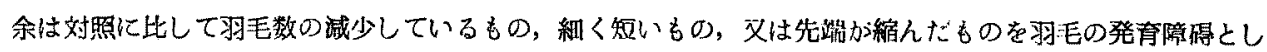

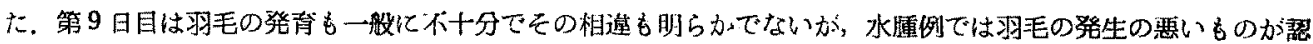
められる。第12日目に於ては $3.0 \mathrm{mg}$ 以上の注射例では全例に，第15日目に於ては2.0mg注射例に 3 例，3.0mg以 上の注射例では全例に，符18日目に於ては2.0mg注射例に4例，3.0 mg以上の注射例では全例てとれ等の变化加 楒められる。

\section{3）浮腫殊に管胞状水腫形成の発生}

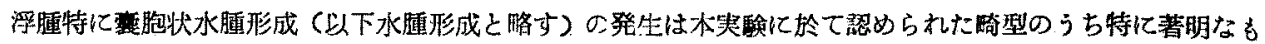

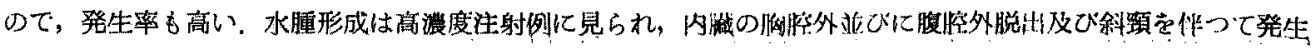

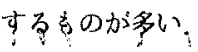




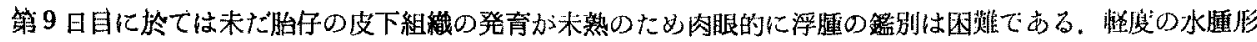

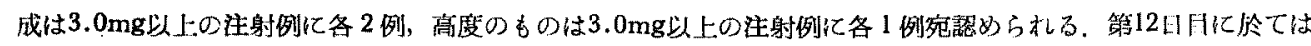
浮腫は $1.0 \mathrm{mg}, 2.0 \mathrm{mg}$ 注射例行各 1 例, 样度の水腫形成は $2.0 \mathrm{mg}$ 注射例飞 2 例, $3.0 \mathrm{mg}$ 以上の注射例に各 1 例,

第 2 表。躬 第 9 日

\begin{tabular}{|c|c|c|c|c|c|c|c|c|c|c|c|c|}
\hline \multirow{2}{*}{ 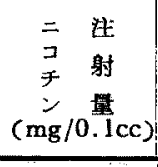 } & \multirow[b]{2}{*}{ (例 } & \multirow{2}{*}{ 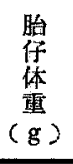 } & \multirow{2}{*}{ 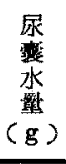 } & \multirow{2}{*}{$\begin{array}{l}\text { 羊 } \\
\text { 水 } \\
\text { 量 } \\
\text { ( g) }\end{array}$} & \multicolumn{2}{|c|}{$(\mathrm{pH})$} & \multicolumn{6}{|c|}{ 肉 眼 的 所 見 } \\
\hline & & & & & $\begin{array}{l}\text { 尿 } \\
\text { 褰 } \\
\text { 水 }\end{array}$ & $\begin{array}{l}\text { 苹 } \\
\text { 水 }\end{array}$ & $\begin{array}{l}\text { 全育 } \\
\text { 童障 } \\
\text { 発碍 }\end{array}$ & $\begin{array}{l}\text { 翏育 } \\
\text { 害障 } \\
\text { 登但 }\end{array}$ & 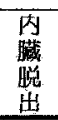 & 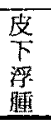 & $\begin{array}{l}\text { 斜 } \\
\text { 鄢 }\end{array}$ & 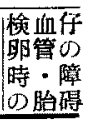 \\
\hline \multirow{2}{*}{ 対 } & 1 & 1.8 & 1.8 & 0.9 & & & - & - & - & - & - & - \\
\hline & 2 & 1.7 & 1.4 & 2.0 & & & - & - & - & - & - & - \\
\hline \multirow{4}{*}{$\begin{array}{l}\text { 照 } \\
\text { 無 } \\
\text { 怒 } \\
\text { 置 }\end{array}$} & 3 & 1.6 & 1.5 & 1.0 & & & - & - & - & - & - & - \\
\hline & 4 & 1.6 & 1.4 & 1.9 & & & - & - & - & - & - & - \\
\hline & 5 & 1.7 & 1.6 & 1.6 & & & 8 & 5 & $\ldots$ & $\ldots$ & & - \\
\hline & 平均 & 1.7 & 1.6 & 1.5 & 7.6 & 6.2 & & & & & & \\
\hline \multirow{6}{*}{0.1} & 1 & 2.1 & 2.6 & 2.0 & & & - & - & - & - & - & - \\
\hline & 2 & 1.9 & 2.6 & 2.0 & & & - & - & - & - & - & - \\
\hline & 3 & 1.9 & 1.7 & 2.4 & & & - & - & - & - & - & - \\
\hline & 4 & 2.3 & 4.2 & 1.8 & & & - & - & - & - & - & - \\
\hline & 5 & 2.3 & 3.7 & 2.0 & & & - & - & - & - & - & - \\
\hline & 平均 & 2.1 & 3.0 & 2.0 & 7.6 & 7.0 & & 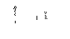 & & & & \\
\hline \multirow{6}{*}{1.0} & I & 2.6 & & & & & - & - & - & - & - & - \\
\hline & 2 & 1.6 & 1.6 & 1.1 & & & - & - & - & - & - & - \\
\hline & 3 & 1.9 & 3.0 & 1.0 & & & - & - & - & - & - & - \\
\hline & 4 & 1.5 & 4.1 & 1.7 & & & - & - & - & - & - & - \\
\hline & 5 & 2.4 & 2.8 & 1.8 & & & - & - & - & - & - & - \\
\hline & 平均 & 2.0 & 3.1 & 1.4 & 7.8 & 7.1 & & & & & & \\
\hline \multirow{6}{*}{2.0} & 1 & 1.4 & 1.6 & 1.7 & & & + & - & - & - & - & + \\
\hline & 2 & 2.0 & 1.0 & 2.0 & & & - & - & - & - & - & - \\
\hline & 3 & 2.2 & 1.8 & 1.9 & & & + & - & - & - & - & - \\
\hline & 4 & 1.5 & 1.2 & 2.0 & & & + & - & - & - & - & + \\
\hline & 5 & 2.5 & 2.2 & 1.8 & & & - & - & - & - & - & + \\
\hline & 平均 & 1.9 & 1.6 & 1.8 & 8.0 & 6.8 & & & & & & \\
\hline \multirow{4}{*}{3.0} & 1 & 1.3 & 1.2 & 1.1 & & & $\#$ & - & + & $H$ & + & + \\
\hline & 2 & 水腫 & & & & & Ht & + & - & \# & + & + \\
\hline & 3 & 1.3 & 1.0 & 1.8 & & & H & - & + & $H$ & + & + \\
\hline & 西均 & 1.3 & 1.1 & 1.5 & 7.7 & 6.8 & & & & & & \\
\hline \multirow{4}{*}{4.0} & 1 & 2.1 & 0.9 & & & & $\#$ & + & - & $\#$ & + & + \\
\hline & 2 & 1.1 & 0.8 & 1.6 & & & H & + & - & $H$ & 1 & + \\
\hline & 3 & 水胛 & & & & & $\#$ & + & - & H & $\uparrow$ & + \\
\hline & 头均 & 1.6 & 0.9 & 1.6 & 7.6 & 6.8 & & & & & & \\
\hline \multirow{4}{*}{5.0} & 1 & 1.5 & 1.6 & 0.9 & & & $\#$ & + & $=$ & $H$ & + & + \\
\hline & 2 & 水腫 & & 2.0 & & & $\#$ & + & - & \# & + & + \\
\hline & 3 & 1.7 & & 0.6 & & & + & + & + & H & + & -1 \\
\hline & 非约 & 1.6 & 1.6 & 1.2 & 7.8 & 6.6 & & & & & & \\
\hline
\end{tabular}


芽了表，雅畉第 12 日目。

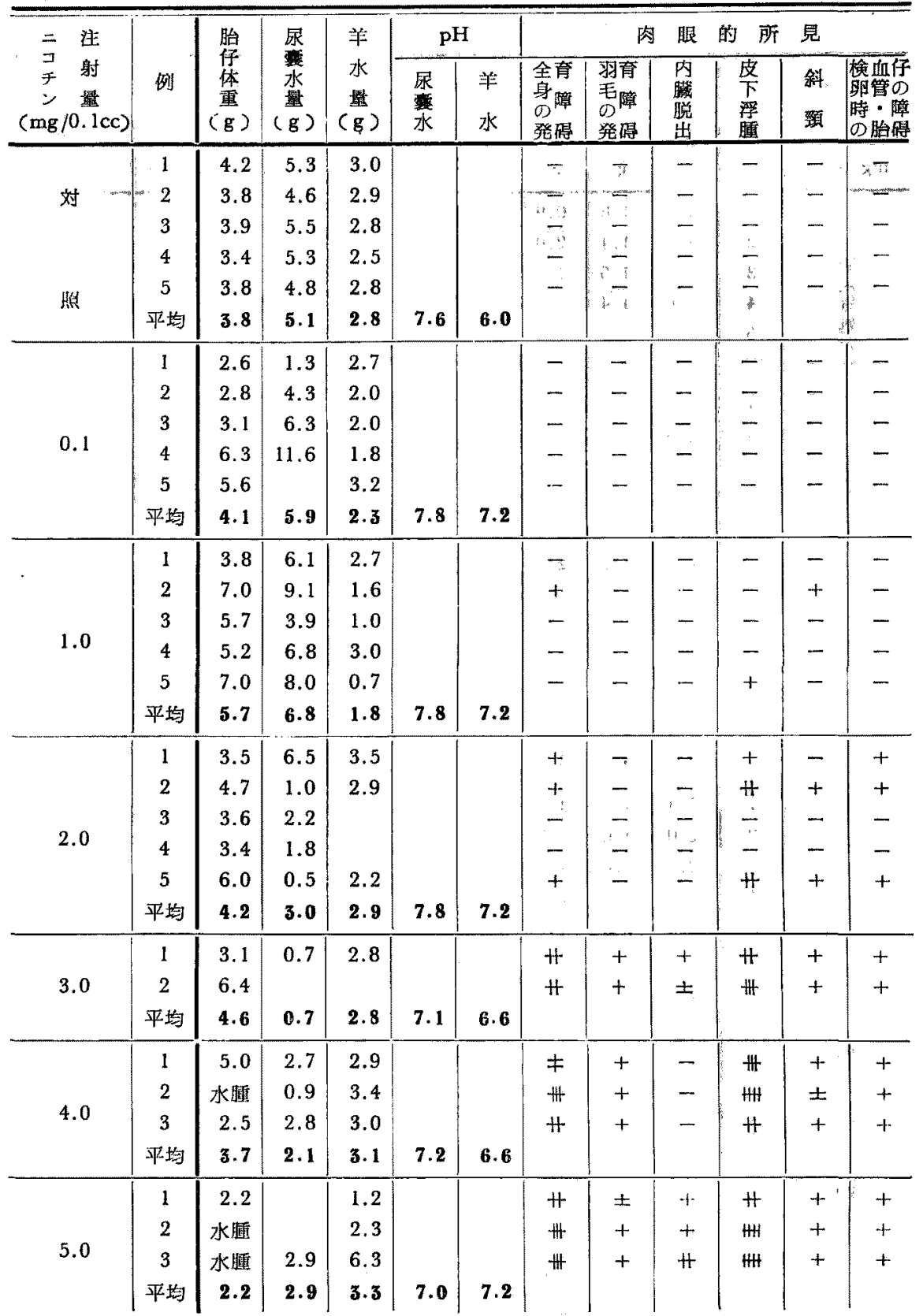




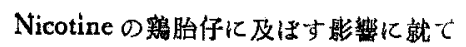

第 4 表。沺 第 15 日 目。

\begin{tabular}{|c|c|c|c|c|c|c|c|c|c|c|c|c|}
\hline \multirow{2}{*}{ 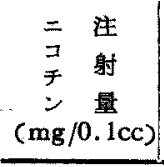 } & \multirow[b]{2}{*}{ 例 } & \multirow{2}{*}{ 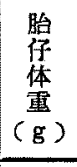 } & \multirow{2}{*}{ 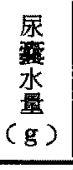 } & \multirow{2}{*}{$\begin{array}{l}\text { 羊 } \\
\text { 水 } \\
\text { 量 } \\
\text { ( } \mathrm{g}) \\
\end{array}$} & \multicolumn{2}{|c|}{$\mathrm{pH}$} & \multicolumn{3}{|c|}{ 肉 眼 } & \multicolumn{2}{|c|}{ 的 所 見 } & \multirow[b]{2}{*}{ 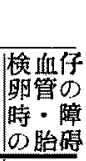 } \\
\hline & & & & & $\begin{array}{l}\text { 丞 } \\
\text { 霡 } \\
\end{array}$ & $\begin{array}{l}\text { 羊 } \\
\text { 水 }\end{array}$ & $\begin{array}{l}\text { 全育 } \\
\text { 等障 } \\
\text { 発碍 }\end{array}$ & $\begin{array}{l}\text { 羽育 } \\
\text { 毛障 } \\
\text { 発碍 }\end{array}$ & 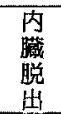 & $\begin{array}{l}\text { 婆 } \\
\text { 浮 } \\
\text { 透 }\end{array}$ & & \\
\hline \multirow{4}{*}{ 対 } & 1 & 8.6 & 8.0 & 3.2 & & & - & - & - & - & - & - \\
\hline & 2 & 9.5 & 2.1 & 4.3 & & & - & - & - & - & - & - \\
\hline & 3 & 10.4 & 3.4 & 1.5 & & & - & - & - & - & - & - \\
\hline & 4 & 17.2 & 4.1 & 6.1 & & & - & - & - & $\therefore$ & $\ldots$ & - \\
\hline \multirow{2}{*}{ 照 } & 5 & 9.5 & 4.0 & 2.3 & & & - & - & - & - & - & - \\
\hline & 平均 & 11.0 & 4.3 & 3.5 & 6.2 & 7.0 & & & & & & \\
\hline \multirow{6}{*}{0.1} & 1 & 11.4 & 4.2 & 4.4 & \multirow[b]{6}{*}{6.3} & \multirow[b]{6}{*}{7.1} & - & - & - & - & - & - \\
\hline & 2 & 14.9 & 9.0 & 1.6 & & & - & - & - & - & - & - \\
\hline & 3 & 19.7 & 4.6 & 4.9 & & & $\therefore$ & - & - & - & - & - \\
\hline & 4 & 15.0 & 10.6 & 4.3 & & & - & $\therefore$ & - & - & - & - \\
\hline & 5 & 15.9 & 6.6 & 5.8 & & & - & - & - & - & - & - \\
\hline & 平㘬 & 16.0 & 7.0 & 4.2 & & & & & & & & \\
\hline \multirow{6}{*}{1.0} & 1 & 11.7 & 5.6 & 5.0 & \multirow[b]{6}{*}{ 6.6 } & \multirow[b]{6}{*}{7.1} & + & - & - & - & - & - \\
\hline & 2 & 8.3 & 11.3 & 4.0 & & & + & - & - & - & - & - \\
\hline & 3 & 14.5 & 8.8 & 2.1 & & & - & - & - & - & - & - \\
\hline & 4 & 12.8 & 7.9 & 4.0 & & & \pm & - & - & - & - & - \\
\hline & 5 & 15.0 & 7.5 & 6.8 & & & - & - & - & - & - & - \\
\hline & 平均 & 12.5 & 8.2 & 4.4 & & & & & & & & \\
\hline \multirow{6}{*}{2.0} & 1 & 7.9 & 8.4 & 0.5 & \multirow{6}{*}{7.4} & \multirow[b]{6}{*}{8.0} & + & - & - & + & + & - \\
\hline & 2 & 8.6 & 5.7 & 3.9 & & & + & - & - & - & - & + \\
\hline & 3 & 15.4 & 2.2 & 0 & & & + & + & - & H & - & - \\
\hline & 4 & 17.9 & 2.7 & 0.5 & & & $H$ & + & + & \# & + & + \\
\hline & 5 & 水腄 & 2.0 & 0.5 & & & $\#$ & + & - & HI & + & + \\
\hline & 平均 & 12.5 & 4.2 & 1.1 & & & & & & & & \\
\hline \multirow{4}{*}{3.0} & 1 & 5.8 & 3.4 & 0.7 & & & H & + & - & $\#$ & + & + \\
\hline & 2 & 水腯 & 3.0 & 0.2 & & & \# & + & - & $H$ & + & + \\
\hline & 3 & 水腄 & 4.2 & 0.5 & & & \# & + & - & HW & + & + \\
\hline & 平均 & 5.8 & 3.5 & 0.5 & 7.2 & 8.2 & & & & & & \\
\hline \multirow{4}{*}{4.0} & 1 & 水婳 & & & & & $H$ & + & - & \# & 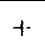 & + \\
\hline & 2 & 水尰 & & & & & H & + & - & 册 & 4 & + \\
\hline & 3 & 水腯 & & & & & \# & $\uparrow$ & - & H & + & $\uparrow$ \\
\hline & 平均 & & & & & & & & & & & \\
\hline \multirow{4}{*}{5.0} & 1 & 水腫 & & & & & \# & + & - & H & + & + \\
\hline & 2 & 水埂 & & & & & \# & + & - & $H$ & + & $\uparrow$ \\
\hline & $\stackrel{3}{3}$ & 水隀 & & & & & \# & + & - & $H$ & + & + \\
\hline & 平均 & & & & & & & & & & & \\
\hline
\end{tabular}


第 5 表. 躬 卵 第 18 日 目。

\begin{tabular}{|c|c|c|c|c|c|c|c|c|c|c|c|c|}
\hline \multirow{2}{*}{ 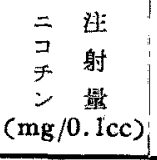 } & \multirow[b]{2}{*}{ 例 } & \multirow{2}{*}{$\begin{array}{c}\text { 胎 } \\
\text { 俰 } \\
\text { 体 } \\
\text { 箸 } \\
(\mathrm{g})\end{array}$} & \multirow{2}{*}{ 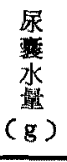 } & \multirow{2}{*}{$\begin{array}{l}\text { 羊 } \\
\text { 水 } \\
\text { 量 } \\
\text { (g) }\end{array}$} & \multicolumn{2}{|c|}{$\mathrm{pH}$} & \multicolumn{6}{|c|}{ 肉 眼 } \\
\hline & & & & & $\begin{array}{l}\text { 㽷 } \\
\text { 檴 } \\
\text { 水 }\end{array}$ & $\begin{array}{l}\text { 米 } \\
\text { 水 }\end{array}$ & $\begin{array}{l}\text { 全育 } \\
\text { 身瞕 } \\
\text { 登碍 } \\
\end{array}$ & $\begin{array}{l}\text { 羽青 } \\
\text { 毛傽 } \\
\text { 登碍 } \\
\end{array}$ & $\begin{array}{l}\text { 内 } \\
\text { 懴 } \\
\text { 总 } \\
\text { 出 }\end{array}$ & $\begin{array}{c}\text { 皮 } \\
\text { 粱 } \\
\text { 腫 } \\
\end{array}$ & $\begin{array}{l}\text { 斜 } \\
\text { 䫫 }\end{array}$ & 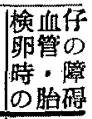 \\
\hline \multirow{4}{*}{ 好 } & 1 & 26.8 & 5.0 & 0.8 & & & - & - & - & - & - & - \\
\hline & 2 & 25.1 & 3.0 & 0.5 & & & - & - & - & - & - & - \\
\hline & 3 & 21.6 & 1.6 & 3.0 & & & - & $T$ & - & - & - & - \\
\hline & 4 & 19.8 & 0.9 & 4.2 & & & - & $T$ & - & - & - & - \\
\hline \multirow{2}{*}{ 珤 } & 5 & 17.8 & 1.3 & 0.6 & & & $=7$ & $=7$ & - & - & - & - \\
\hline & 平管 & 22.2 & 2.4 & 1.8 & 6.3 & 7.3 & & & & & & \\
\hline \multirow{6}{*}{0.1} & 1 & 23.7 & 4.6 & 1.0 & & & - & - & - & - & - & - \\
\hline & 2 & 23.0 & 0.8 & 3.8 & & & - & - & - & $T$ & - & - \\
\hline & 3 & 23.8 & 2.5 & 1.3 & & & - & $T$ & - & - & - & - \\
\hline & 4 & 24.9 & 5.9 & 0.5 & & & - & - & - & - & - & - \\
\hline & 5 & 21.7 & 3.5 & 0.8 & & & - & - & - & - & - & - \\
\hline & 承均 & 23.4 & 3.5 & 1.5 & 6.6 & 7.6 & & & & & & \\
\hline \multirow{6}{*}{1.0} & 1 & 24.2 & 3.5 & 0.4 & & & $H$ & - & - & H & - & - \\
\hline & 2 & 20.8 & 4.2 & 1.2 & & & $H$ & - & - & HI & + & - \\
\hline & 3 & 21.9 & 6.2 & 1.3 & & & - & - & - & - & - & - \\
\hline & 4 & 22.9 & 2.6 & 1.6 & & & - & - & - & + & - & - \\
\hline & 5 & 19.5 & 2.8 & 0.2 & & & - & - & - & - & - & - \\
\hline & 平均 & 21.9 & 3.9 & 0.9 & 6.4 & 7.2 & & & & & & \\
\hline \multirow{5}{*}{2.0} & 1 & 12.2 & 2.5 & 2.1 & & & + & - & - & - & + & + \\
\hline & 2 & 18.0 & 2.7 & 0 & & & HI & + & - & \# & + & + \\
\hline & 3 & 17.8 & 1.2 & 0.2 & & & HI & + & - & $H$ & + & + \\
\hline & 4 & 13.0 & 3.2 & 1.5 & & & + & + & $i^{-}$ & + & + & + \\
\hline & $\begin{array}{c}5 \\
\text { 平蚫 }\end{array}$ & 水腫 & & & 6.6 & 7.8 & H & + & i & HII & + & + \\
\hline \multirow{4}{*}{3.0} & 1 & 水腄 & 4.4 & 1.7 & & & \# & + & -1 & HI & $H$ & + \\
\hline & 2 & 11.8 & 2.7 & & & & \# & + & + & + & $H$ & + \\
\hline & 3 & 水腫 & & & & & H & + & - & HEH & + & + \\
\hline & 平均 & 11.8 & 3.6 & 1.7 & 6.6 & 7.8 & & & & & & \\
\hline 4.0 & 1 & 麻 & 速 & 例 & & & Ht & + & - & + & $H$ & + \\
\hline
\end{tabular}

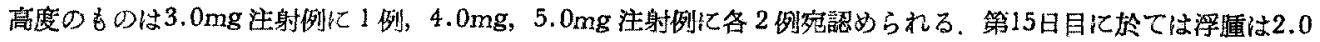

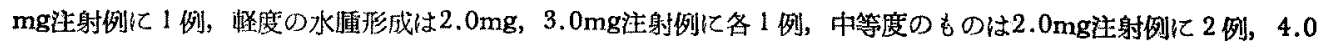

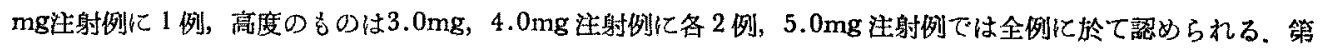

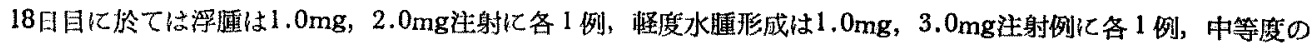

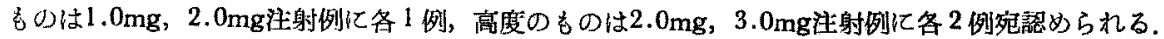

\section{4)內腰の胸堙並びに腹腔外脱出}

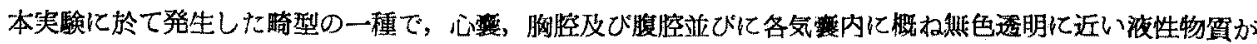
斯溜し，そのまま直腹筋を開雕し，体外に脱出しだるのである。

第 9 日目は3.0mg注射例に 2 例，5.0 $\mathrm{mg}$ 泣射例に 1 例，第 12 日目は $3.0 \mathrm{mg}$ 注射例に 2 例，5.0 $\mathrm{mg}$ 注射例に 3

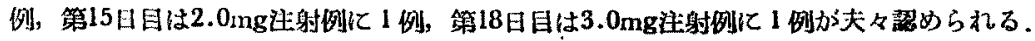




\section{5)利頕の発生}

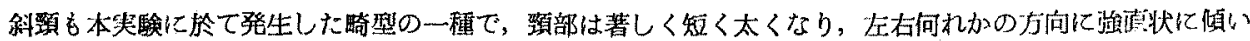

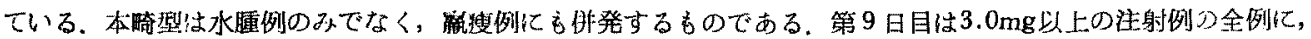

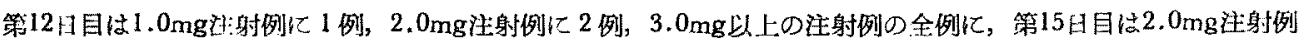
に 3 例， $3.0 \mathrm{mg}$ 以上の主射例の全例に，第18日目は $1.0 \mathrm{mg}$ 注射例に I 例， $2.0 \mathrm{mg}$ 注射例の全例に柽度の6のが， $3.0 \mathrm{mg}, 4.0 \mathrm{mg}$ 注射では全例に著明な本畸型を認めた。

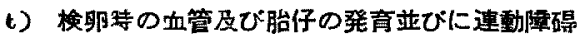

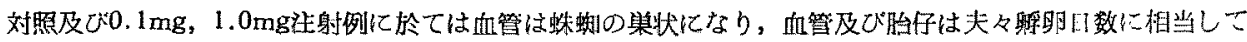

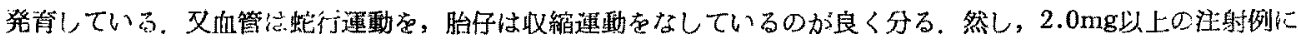

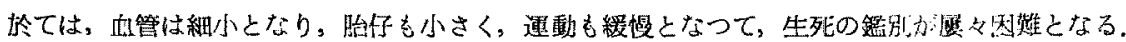

\section{C. 組織学的所兒 \\ I . 皮成の組緯学的所見}

1) 䀲莭第9日目 (第 6 表)

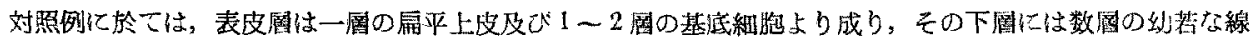

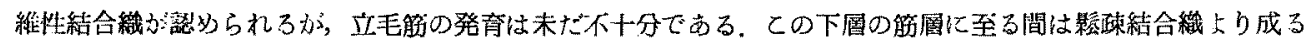

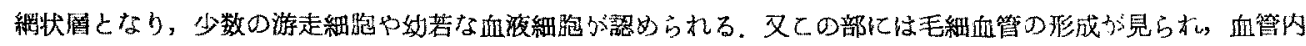

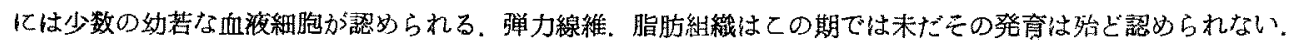

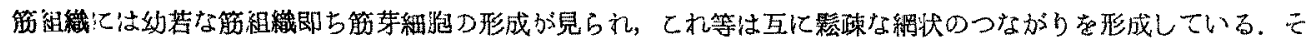

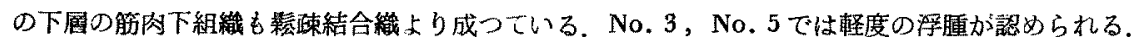

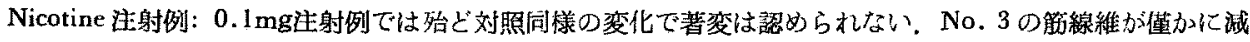

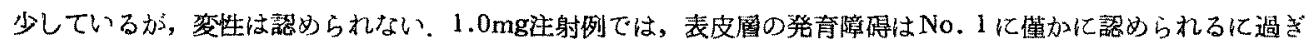

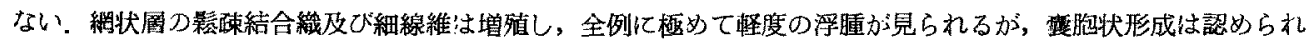
ない，筇組織の発育障碍は柽度であるが全例に見られ，No.1，No.5では他に比して稍々強い，2.0mg注射例 では表皮層の発育㽝碍が晃られ，表皮圈も菲薄となつている，乙れに反し網状風は增殖し，細線維は増加してい

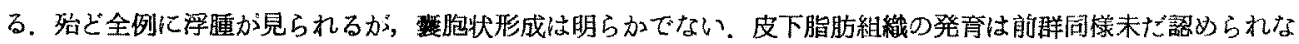

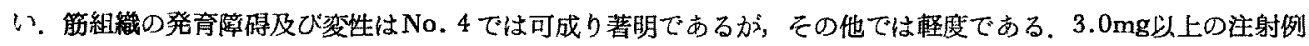

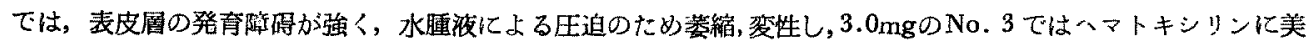

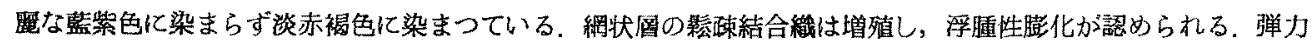
線維の発育は明らかでない，游走細胞も僅が增加し，3.0mgのNo. 3 及び5.0mgつ2例では可成り渚明である。

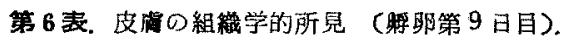

\begin{tabular}{|c|c|c|c|c|c|c|c|c|c|c|c|}
\hline 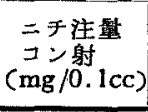 & 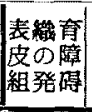 & $\begin{array}{l}\text { 立線 } \\
\text { 专 } \\
\text { 維維 }\end{array}$ & 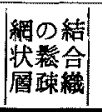 & $\begin{array}{l}\text { 細 } \\
\text { 線 } \\
\text { 維 }\end{array}$ & $\begin{array}{l}\text { 弾線 } \\
\text { 力維 }\end{array}$ & $\begin{array}{l}\text { 游細 } \\
\text { 走胞 }\end{array}$ & $\begin{array}{l}\text { 皮肪 } \\
\text { 下縝 } \\
\text { 脂緇 }\end{array}$ & $\mid$ & $\begin{array}{l}\text { 筋の } \\
\text { 線䒾 } \\
\text { 維性 }\end{array}$ & 䟹 & 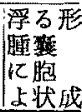 \\
\hline \multirow[b]{2}{*}{ 対 } & - & - & + & + & - & + & - & - & - & $\cdots$ & - \\
\hline & - & - & + & + & - & + & - & - & - & - & - \\
\hline \multirow[b]{2}{*}{ 哭 } & - & - & + & + & - & + & - & - & - & \pm & - \\
\hline & - & - & $H$ & $H$ & - & + & - & - & - & \pm & - \\
\hline \multirow{5}{*}{0.1} & - & - & + & + & - & + & - & - & - & \pm & - \\
\hline & - & - & + & + & - & + & - & - & - & \pm & - \\
\hline & - & - & + & + & - & + & - & \pm & - & \pm & - \\
\hline & - & - & + & + & - & + & - & - & - & \pm & - \\
\hline & - & - & \pm & \pm & - & + & - & - & - & \pm & - \\
\hline
\end{tabular}




\begin{tabular}{|c|c|c|c|c|c|c|c|c|c|c|c|}
\hline 1.0 & $\begin{array}{l} \pm \\
- \\
- \\
- \\
-\end{array}$ & $\begin{array}{l}- \\
- \\
- \\
- \\
-\end{array}$ & $\begin{array}{l}H \\
+ \\
H \\
H \\
+\end{array}$ & $\begin{array}{l}+ \\
+ \\
+ \\
+ \\
+\end{array}$ & $\begin{array}{l}- \\
- \\
- \\
- \\
-\end{array}$ & $\begin{array}{l}+ \\
+ \\
+ \\
+ \\
+\end{array}$ & $\begin{array}{l}- \\
- \\
- \\
- \\
-\end{array}$ & $\begin{array}{l}+ \\
\pm \\
\pm \\
\pm \\
+\end{array}$ & $\begin{array}{l}+ \\
\pm \\
\pm \\
\pm \\
+\end{array}$ & $\begin{array}{l} \pm \\
\pm \\
\pm \\
+ \\
+\end{array}$ & $\begin{array}{l}- \\
- \\
- \\
-\end{array}$ \\
\hline 2.0 & $\begin{array}{l}+ \\
+ \\
+ \\
+ \\
\pm\end{array}$ & $\begin{array}{l}- \\
- \\
- \\
- \\
-\end{array}$ & $\begin{array}{l}H \\
H \\
H \\
H \\
+\end{array}$ & $\begin{array}{l}H \\
H \\
H \\
H \\
+\end{array}$ & $\begin{array}{l}- \\
- \\
- \\
- \\
-\end{array}$ & $\begin{array}{l}+ \\
+ \\
+ \\
+ \\
+\end{array}$ & $\begin{array}{l}- \\
- \\
- \\
- \\
-\end{array}$ & $\begin{array}{l}+ \\
+ \\
+ \\
+ \\
+\end{array}$ & $\begin{array}{l}+ \\
+ \\
+ \\
+ \\
+\end{array}$ & $\begin{array}{l}H \\
H \\
H \\
H \\
H\end{array}$ & $\begin{array}{l}- \\
- \\
- \\
\pm \\
\pm\end{array}$ \\
\hline 3.0 & $\begin{array}{l}+ \\
+ \\
+\end{array}$ & $\begin{array}{l}- \\
- \\
-\end{array}$ & $\begin{array}{l}H \\
H \\
+\end{array}$ & $\begin{array}{l}+ \\
+ \\
+\end{array}$ & $\begin{array}{l}- \\
- \\
-\end{array}$ & $\begin{array}{l}+ \\
+ \\
+\end{array}$ & $\begin{array}{l}- \\
- \\
-\end{array}$ & $\begin{array}{l}+ \\
+ \\
H\end{array}$ & $\begin{array}{l}+ \\
+ \\
+\end{array}$ & $\begin{array}{l}H \\
H \\
H\end{array}$ & $\begin{array}{l} \pm \\
+ \\
\pm\end{array}$ \\
\hline 4.0 & $\begin{array}{l} \pm \\
+ \\
+\end{array}$ & $\begin{array}{l}- \\
- \\
-\end{array}$ & $\begin{array}{l}\text { III } \\
H \\
H\end{array}$ & $\begin{array}{l}+ \\
+ \\
-\end{array}$ & $\begin{array}{l}- \\
- \\
-\end{array}$ & $\begin{array}{l}+ \\
+ \\
+\end{array}$ & $\begin{array}{l}- \\
- \\
-\end{array}$ & $\begin{array}{l}H \\
+ \\
H\end{array}$ & $\begin{array}{l}H \\
+ \\
H\end{array}$ & $\begin{array}{l}H \\
H \\
H\end{array}$ & $\begin{array}{l}H \\
H \\
H\end{array}$ \\
\hline 5.0 & $\begin{array}{l}H \\
H\end{array}$ & - & $\begin{array}{l}\# \\
H\end{array}$ & $\begin{array}{l}+ \\
-\end{array}$ & - & $\begin{array}{l}H \\
H\end{array}$ & - & $\begin{array}{l}H \\
H\end{array}$ & $\begin{array}{l}H \\
H\end{array}$ & $\begin{array}{l}H \\
H\end{array}$ & $\begin{array}{l}H \\
H\end{array}$ \\
\hline
\end{tabular}

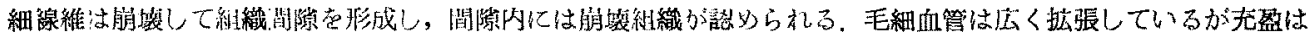

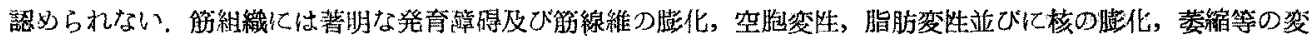
化小㑇められ号。

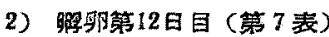

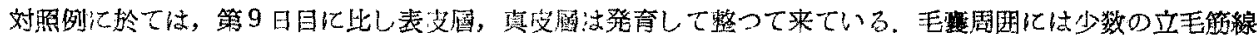

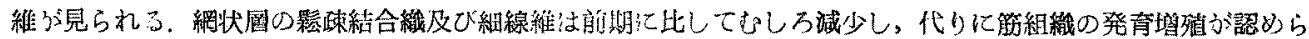

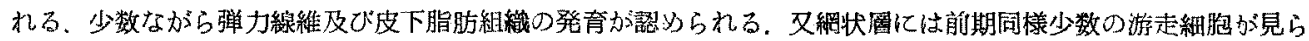

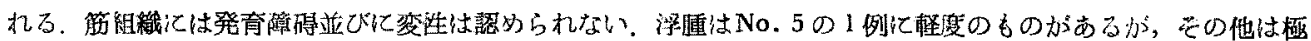
めて鞋度である。

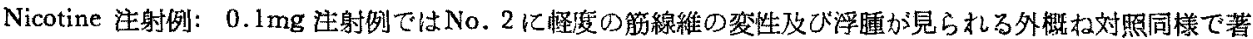

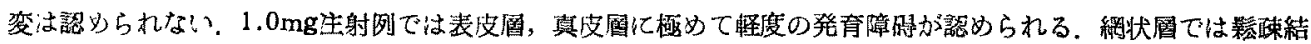

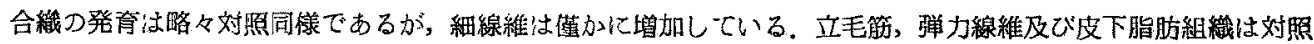

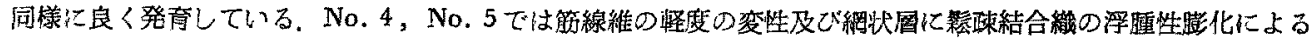

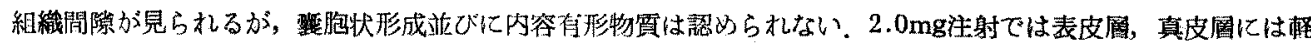

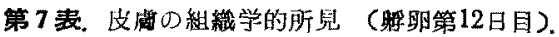

\begin{tabular}{|c|c|c|c|c|c|c|c|c|c|c|c|}
\hline 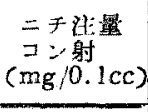 & 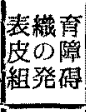 & $\begin{array}{l}\text { 空線 } \\
\text { 毛 } \\
\text { 綝維 }\end{array}$ & 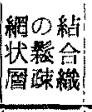 & $\begin{array}{l}\text { 緥 } \\
\text { 線 } \\
\text { 維 }\end{array}$ & $\begin{array}{l}\text { 弾線 } \\
\text { 力維 }\end{array}$ & $\begin{array}{l}\text { 游絸 } \\
\text { 走胞 }\end{array}$ & 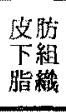 & 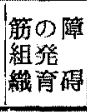 & $\begin{array}{l}\text { 筋の } \\
\text { 線卒 } \\
\text { 維栍 }\end{array}$ & $\begin{array}{l}\text { 浮 } \\
\text { 玼 } \\
\end{array}$ & 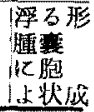 \\
\hline \multirow{3}{*}{ 奶 } & - & \pm & + & -1 & \pm & 7 & \pm & - & - & \pm & - \\
\hline & - & \pm & + & + & \pm & + & \pm & - & - & \pm & - \\
\hline & - & \pm & + & + & \pm & + & \pm & - & - & \pm & - \\
\hline \multirow[b]{2}{*}{ 照 } & - & \pm & + & + & + & + & - & - & - & \pm & - \\
\hline & - & \pm & \# & + & + & + & \pm & - & \pm & + & - \\
\hline
\end{tabular}




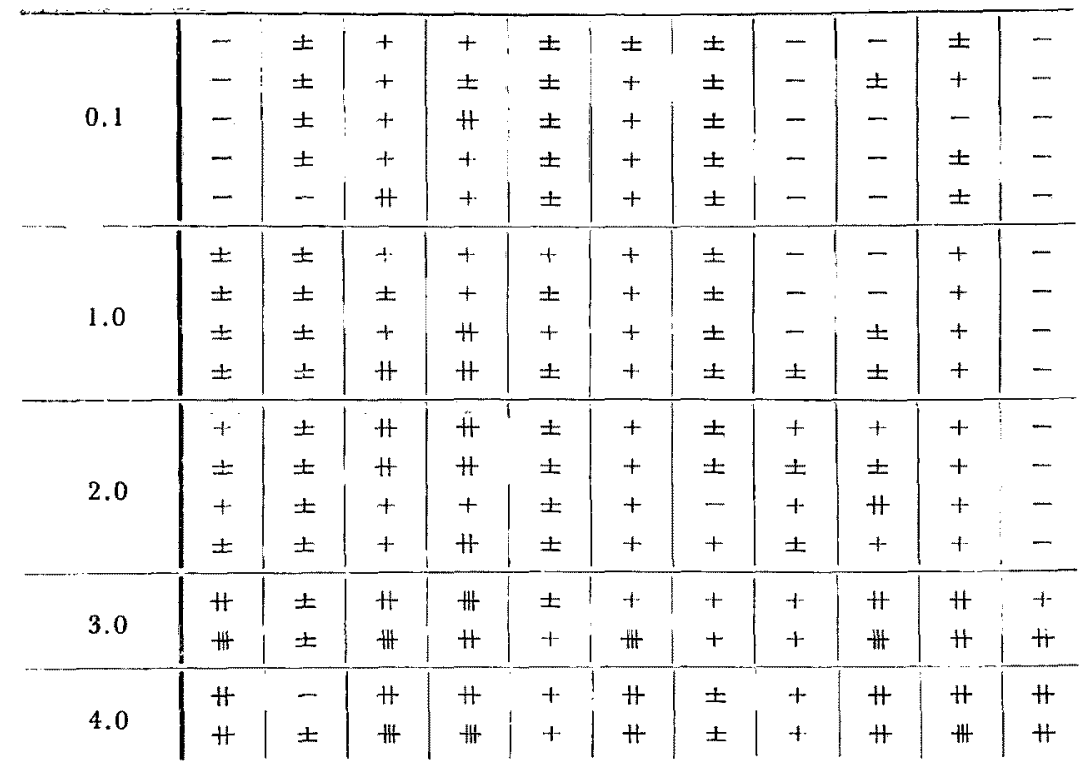

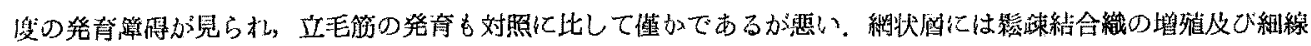

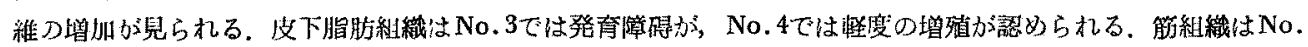

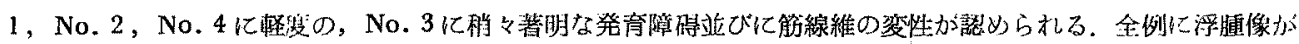

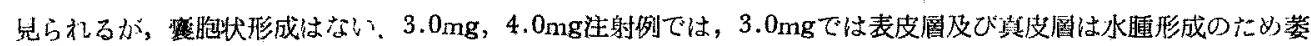

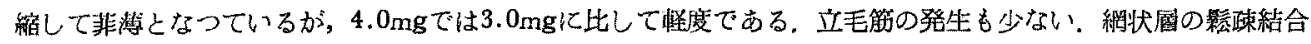

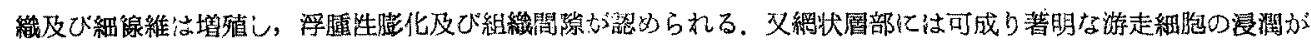

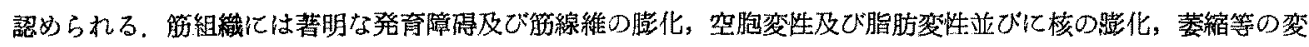
化が認められる。

\section{3) 鹏門第15日目 (第 8 表)}

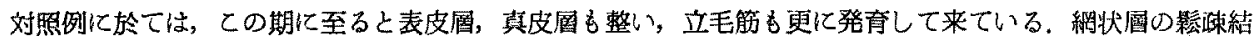
合織も発育增殖しているが，皮下脂脏組織及び筋組織の発育のため著朋とは云い難い，又少数の游走紐胞の見ら れるととは前期同様である.弾力線維の発有增㥀は18日目に比して少ないが，12日目より明らかである。皮下脂

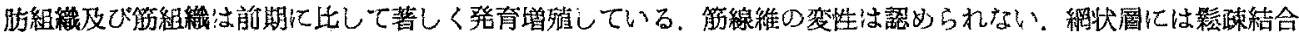
蟣の軽度の浮腫性膨化が見られるが，胎生期としては正常として考えて良いと思われる。

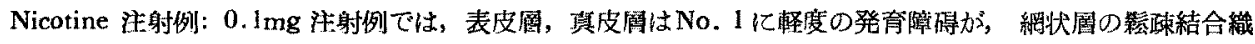

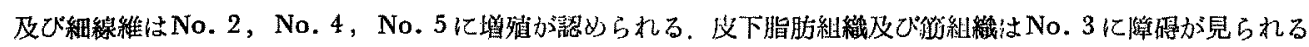

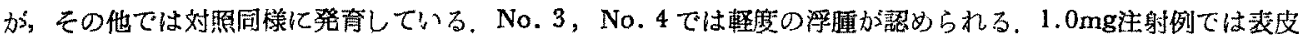

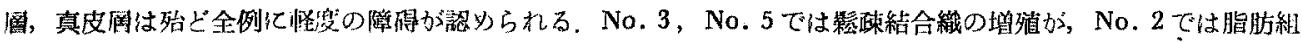

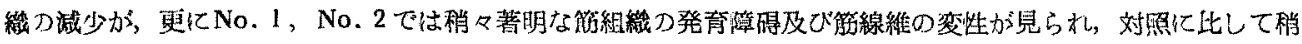

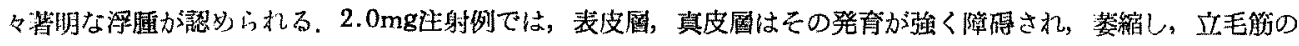

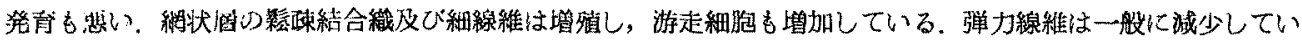

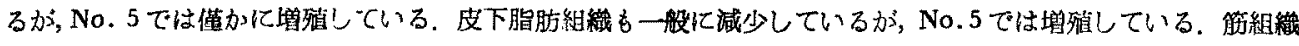

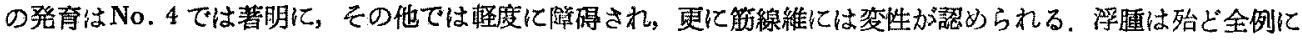

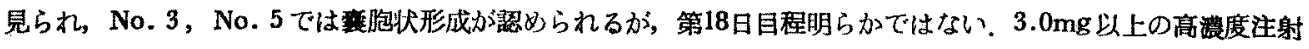

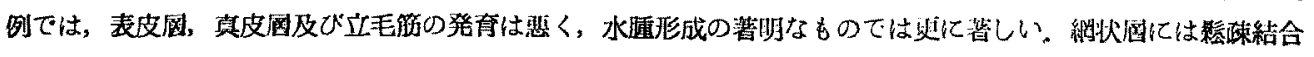




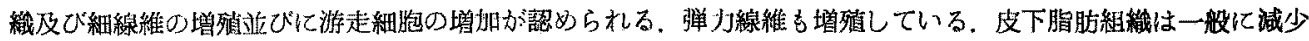

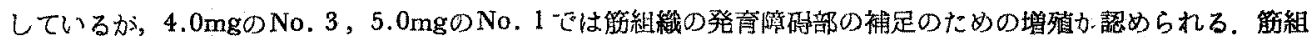

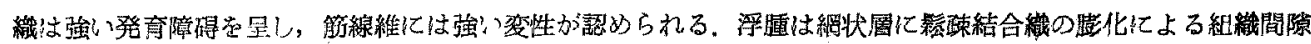

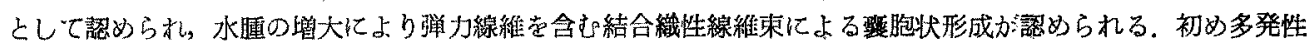

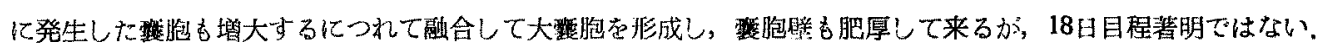
又有形队容与極めて少ない?

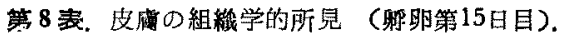

\begin{tabular}{|c|c|c|c|c|c|c|c|c|c|c|c|}
\hline 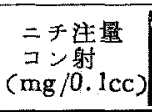 & 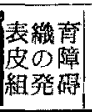 & 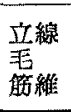 & 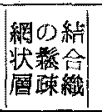 & $\begin{array}{l}\text { 細 } \\
\text { 線 } \\
\text { 維 }\end{array}$ & $\begin{array}{l}\text { 临楾 } \\
\text { 加䧽 }\end{array}$ & $\begin{array}{l}\text { 游緗 } \\
\text { 走狍狍 }\end{array}$ & $\begin{array}{l}\text { 皮肪 } \\
\text { 下組 } \\
\text { 脂䉽 }\end{array}$ & 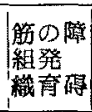 & 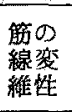 & $\begin{array}{l}\text { 浮 } \\
\text { 璡 }\end{array}$ & 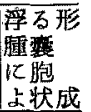 \\
\hline \multirow{3}{*}{ 対 } & - & + & - & †. & + & 4 & $H$ & - & - & \pm & - \\
\hline & - & + & $t$ & -1 & + & -1 & $H$ & - & - & \pm & - \\
\hline & - & + & + & + & + & -1 & $H$ & $1-$ & - & \pm & - \\
\hline \multirow[b]{2}{*}{ 脰 } & - & + & + & + & + & - & $H$ & - & - & \pm & - \\
\hline & - & + & + & + & + & + & \# & - & - & \pm & - \\
\hline \multirow{5}{*}{0.1} &.+ & \pm & + & + & $H$ & + & + & - & - & \pm & - \\
\hline & - & \pm & $H$ & $H$ & + & + & + & - & - & \pm & - \\
\hline & - & \pm & + & + & + & + & - & \pm & - & + & - \\
\hline & - & \pm & Ht & $H$ & + & + & $H$ & - & - & + & - \\
\hline & - & + & H & $H$ & + & + & \# & - & - & \pm & - \\
\hline \multirow{5}{*}{1.0} & + & \pm & + & + & \pm & + & $t$ & + & \pm & + & - \\
\hline & \pm & \pm & + & + & + & + & \pm & + & + & + & - \\
\hline & + & \pm & +4 & $H$ & + & + & $H$ & - & - & \pm & - \\
\hline & \pm & \pm & + & + & + & + & $H$ & - & - & \pm & - \\
\hline & - & + & $H$ & $H$ & + & + & \# & - & - & \pm & - \\
\hline \multirow{5}{*}{2.0} & + & \pm & $H$ & $H$ & \pm & + & \pm & + & - & + & \pm \\
\hline & + & \pm & H & \pm & \pm & + & \pm & + & + & + & \pm \\
\hline & $H$ & + & $\#$ & $H$ & + & \# & $\#$ & + & + & + & + \\
\hline & $H$ & - & $H$ & 将 & \pm & \# & \pm & $H$ & $H$ & + & \pm \\
\hline & H & \pm & \# & $\#$ & $H$ & + & H & \pm & + & $H$ & + \\
\hline \multirow[b]{2}{*}{3.0} & \pm & + & $H$ & $H$ & $t$ & $H$ & + & + & + & $H$ & + \\
\hline & + & \pm & H & $H$ & + & + & + & + & + & $H$ & H \\
\hline \multirow{3}{*}{4.0} & $H$ & \pm & 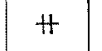 & $H$ & $H$ & $\#$ & + & $H$ & $t$ & $H$ & tht \\
\hline & + & \pm & $\#$ & $H$ & $H$ & + & \pm & + & + & + & + \\
\hline & $H$ & + & $H$ & Hth & $\#$ & $\#$ & $\#$ & $H$ & H & \# & H \\
\hline \multirow{3}{*}{5.0} & + & + & \# & $H$ & $H$ & $H$ & $\#$ & + & H & $H$ & + \\
\hline & $H$ & \pm & H & + & $\#$ & $\#$ & $H$ & $H$ & $H$ & H & \# \\
\hline & $H$ & + & \# & $H$ & + & $\#$ & + & + & $\#$ & \# & $\#$ \\
\hline
\end{tabular}

\section{4) 脬卵第18日目(第9 表)}

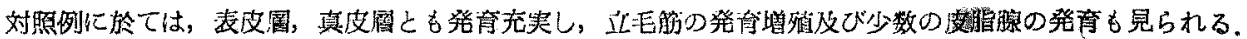

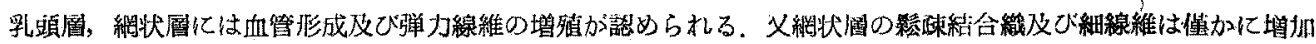

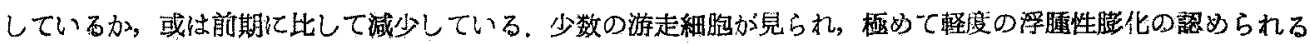

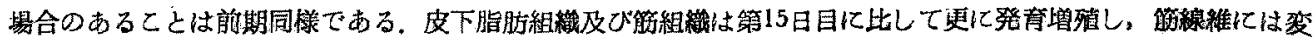
生は䍿められない。 


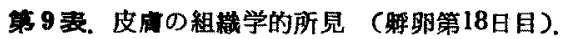

\begin{tabular}{|c|c|c|c|c|c|c|c|c|c|c|c|}
\hline $\begin{array}{c}\text { 二于注量 } \\
コ ン \text { 射 } \\
(\mathrm{mg} / 0.1 \mathrm{cc})\end{array}$ & 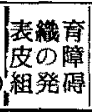 & 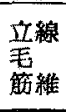 & 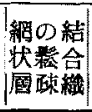 & $\begin{array}{l}\text { 練 } \\
\text { 線 } \\
\text { 維 }\end{array}$ & $\begin{array}{l}\text { 弾線 } \\
\text { 力維 }\end{array}$ & $\begin{array}{l}\text { 游細 } \\
\text { 走胞 }\end{array}$ & $\begin{array}{l}\text { 皮肪 } \\
\text { 下縝 } \\
\text { 脂緎 }\end{array}$ & $\mid$ & $\begin{array}{l}\text { 第の } \\
\text { 線㗹 } \\
\text { 䊒栍 }\end{array}$ & 睡 & 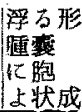 \\
\hline \multirow{3}{*}{ 対 } & - & + & + & + & $\#$ & + & $\mathbb{M}$ & - & - & \pm & - \\
\hline & 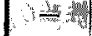 & + & + & + & $\#$ & + & $\#$ & - & - & \pm & - \\
\hline & - & + & + & + & $H$ & + & \# & - & - & \pm & - \\
\hline \multirow[b]{2}{*}{ 照 } & - & + & + & + & $H$ & + & $\#$ & - & - & \pm & - \\
\hline & - & + & + & + & $H$ & + & \# & - & - & \pm & \pm \\
\hline \multirow{5}{*}{0.1} & $x-4:$ & H & + & + & $H$ & + & \# & - & - & \pm & - \\
\hline & - & + & + & + & $H$ & - & \# & - & - & \pm & -- \\
\hline & - & + & $H$ & + & H & + & \# & - & - & \pm & - \\
\hline & \pm & \pm & + & + & $H$ & + & $H$ & - & - & + & - \\
\hline & - & $\#$ & H & $H$ & $H$ & + & \# & - & - & + & - \\
\hline \multirow{5}{*}{1.0} & $H$ & \pm & $\#$ & $\#$ & \pm & + & \pm & \pm & + & + & \pm \\
\hline & $\#$ & \pm & $\#$ & $\#$ & + & + & + & + & $H$ & $H$ & + \\
\hline & \pm & + & $H$ & \# & + & + & $H$ & \pm & - & \pm & \pm \\
\hline & + & \pm & + & \# & - & + & + & \pm & $\#$ & + & \pm \\
\hline & \pm & + & $\#$ & $H$ & $H$ & + & H & \pm & - & \pm & \pm \\
\hline \multirow{5}{*}{2.0} & \pm & \pm & + & + & + & $H$ & \# & + & + & + & \pm \\
\hline & $H$ & + & H & H & H & $H$ & \# & \pm & + & \# & + \\
\hline & Ht & \pm & \# & H & $\#$ & $H$ & $H$ & \pm & \pm & $\#$ & $H$ \\
\hline & + & \pm & \# & \# & + & $H$ & $H$ & - & + & $\#$ & - \\
\hline & $\#$ & + & Hit & \# & \# & + & $H$ & + & + & \# & H \\
\hline \multirow{3}{*}{3.0} & \# & \pm & \# & $\#$ & $H$ & $H$ & $H$ & \pm & \pm & \# & \# \\
\hline & + & + & + & + & + & + & $\#$ & \pm & + & + & + \\
\hline & H & \pm & $H$ & + & $H$ & $H$ & $H$ & $T$ & + & $H$ & $\#$ \\
\hline 4.0 & + & \# & $\#$ & H & + & + & 世 & H & + & + & + \\
\hline
\end{tabular}

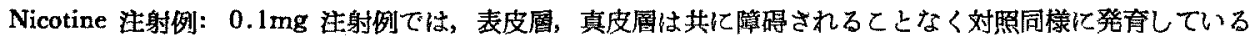

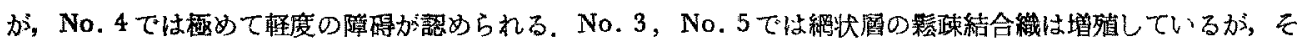

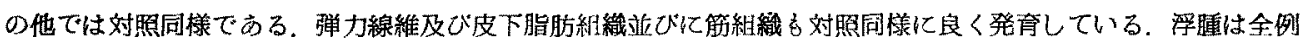

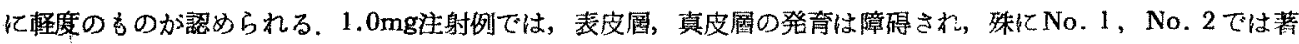

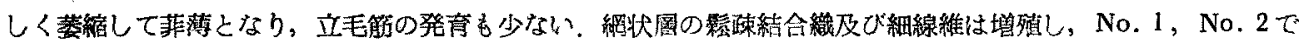
は著明な増殖が認められる，一般弾力線維は少ないか，No. 5 では良く発育している．皮下脂肪絸織は娍少し ているか゚，No. 3，No.5では可成り良く発育している。筋組織も発育加障碍され，No.1，No. 2，No.4で

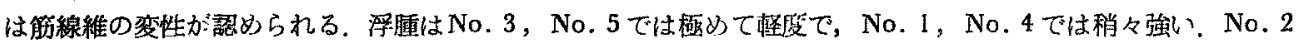

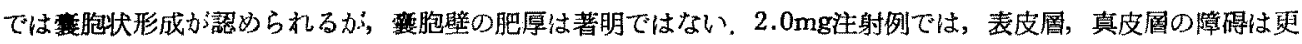

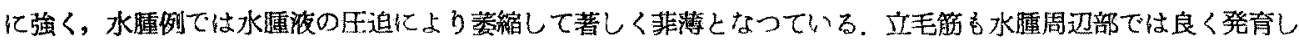

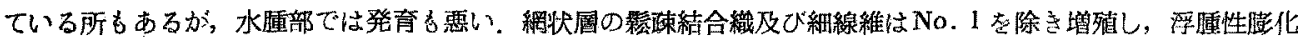

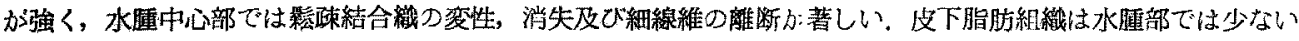

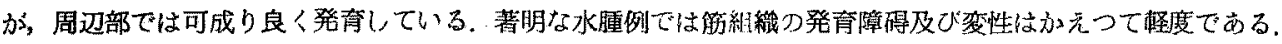

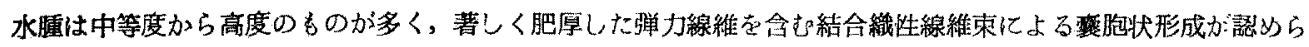

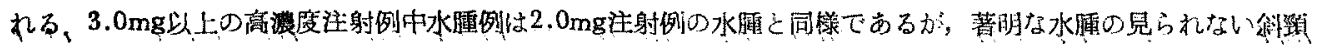




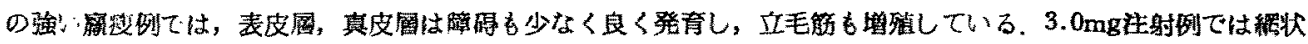

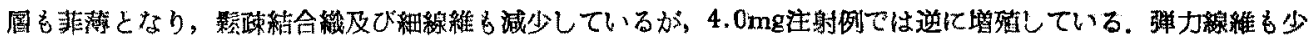

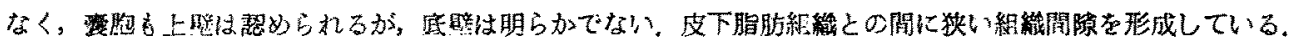

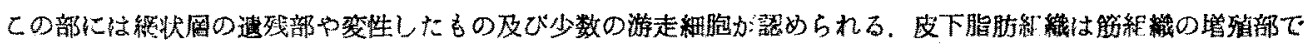

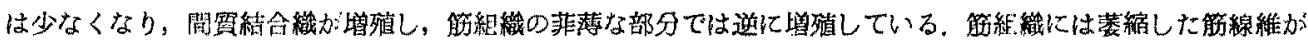

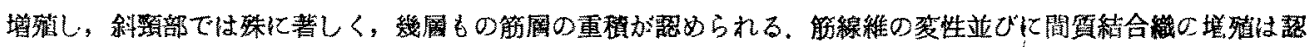
めるれるい。

I. 水腫の肉眼的亚びに組維学的所見

1) 水腄の分類

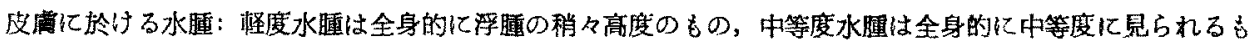

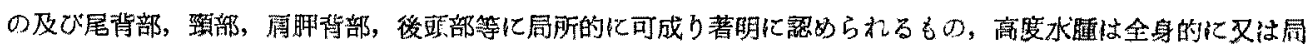

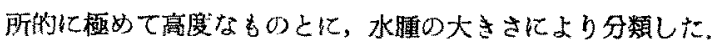

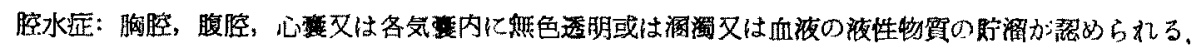

2）水腆の発生部位

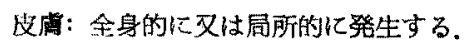

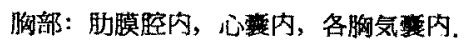

腹部：腹腔内，各腹気覲内。

3) 皮窝の高度水腫の肉眼的所見

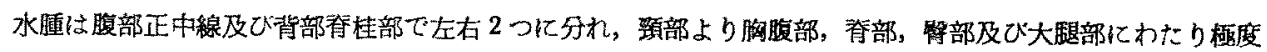

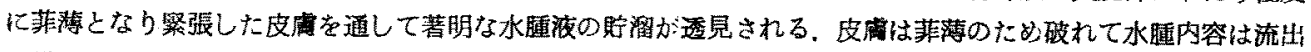

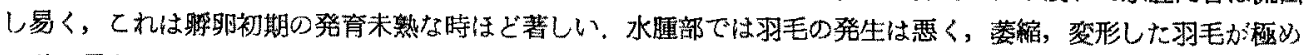

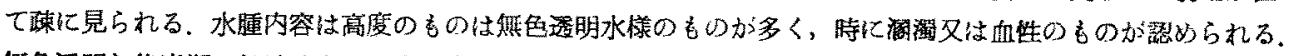

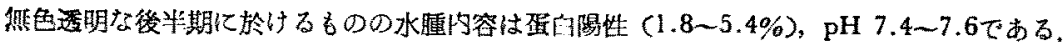

\section{4) 水哃の組織学的所見}

a) 各時期に於ける潆睡及び水睡

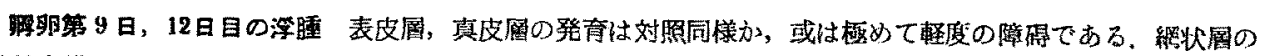

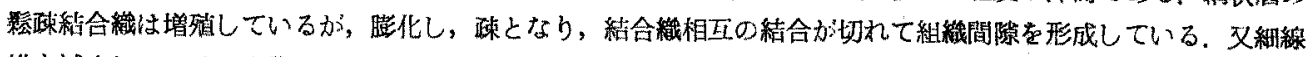

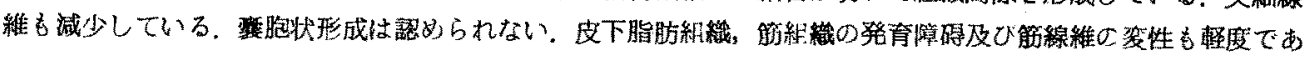
๖.

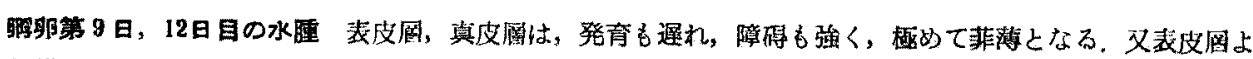

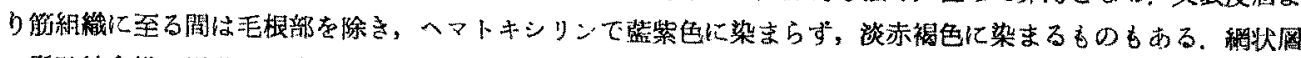

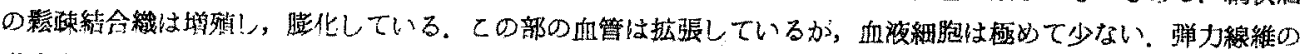

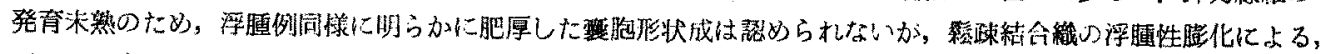

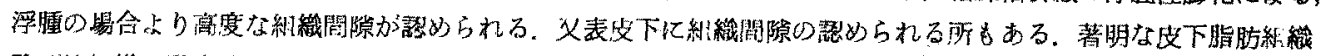

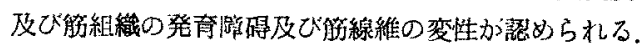

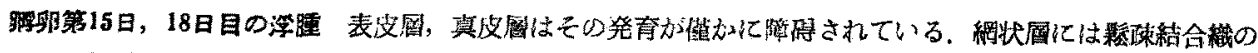

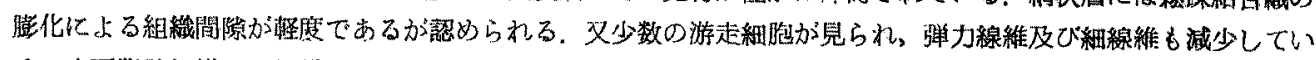

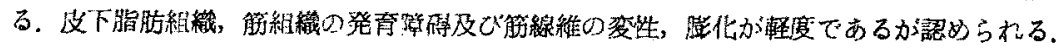

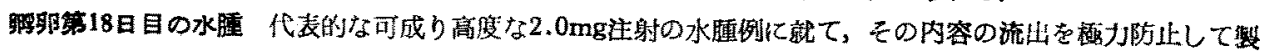

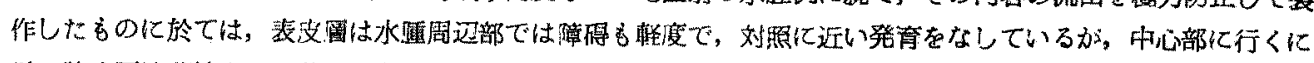

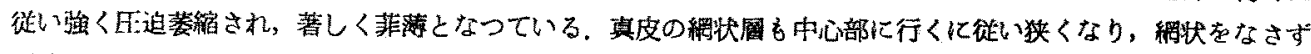

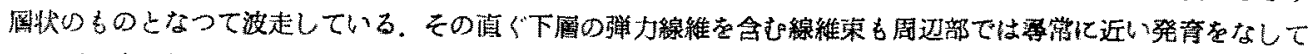

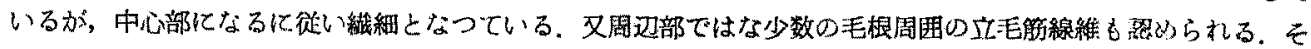

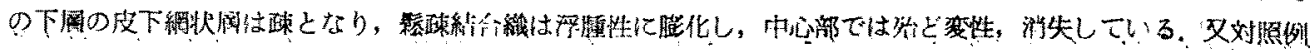




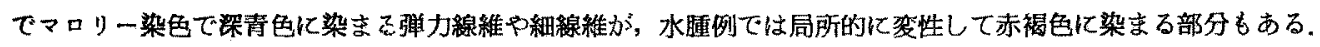

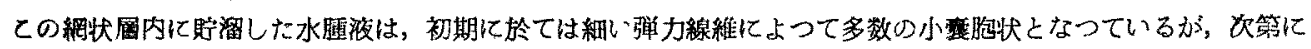

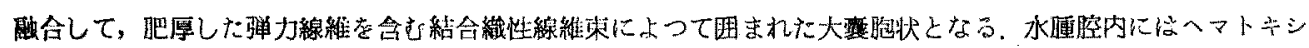

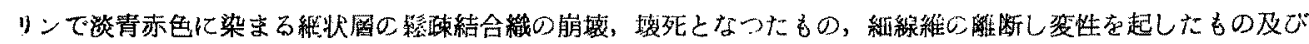

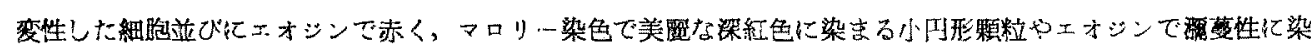

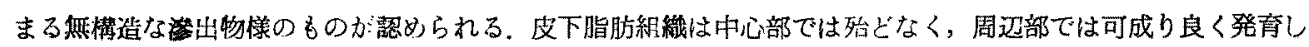

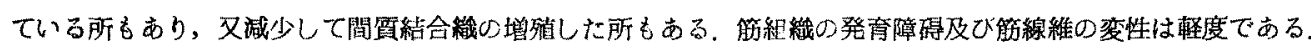

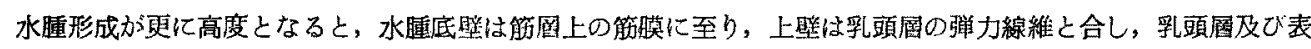

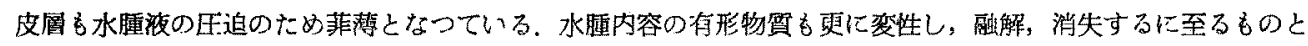
思われる。

\section{b) 冰症の皮成所見}

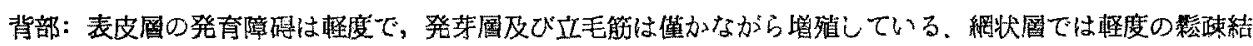

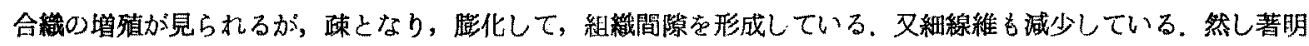

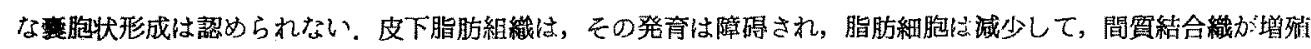

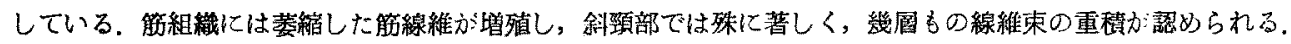
又所により筋線維の膨化及び変性が見られる。

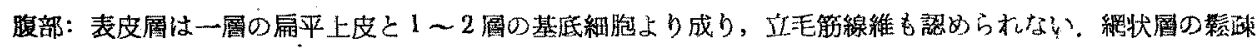

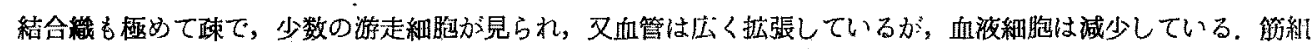

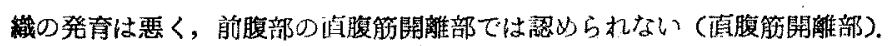

\section{I. 䀒勒の組織学的所見}

組蟣学的検索に当り，次の如く分類して，肝藏の発育並びに悢織障㥂に就て検討した。

$\begin{array}{llll}\text { 対 } & \text { 照群 } & \text { 低 処 置 例 } \\ \text { 第 } & 1 & \text { 群 } & 0.1 \mathrm{mg} \text { 注射例 } \\ \text { 第 } & 2 & \text { 群 } & 1.0 \mathrm{mg} \text { 注射例 } \\ \text { 第 } & 3 & \text { 群 } & 2.0 \mathrm{mg} \text { 注 射例 } \\ \text { 第 } & 4 & \text { 群 } & 3.0 \mathrm{mg}, 4.0 \mathrm{mg}, 5.0 \mathrm{mg} \text { 注 射例 }\end{array}$

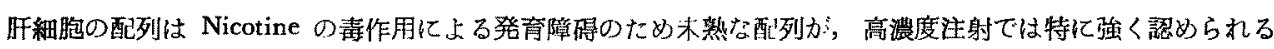
ので，その発育に從い，配列の不全度により次の如く分頪した。

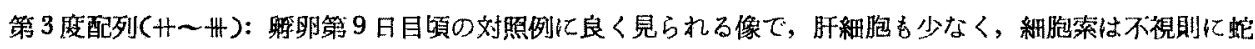

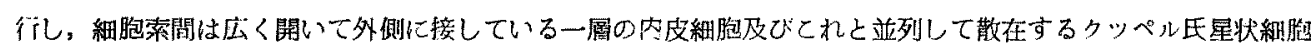

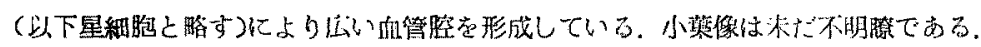

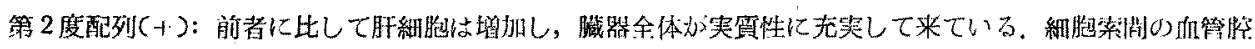

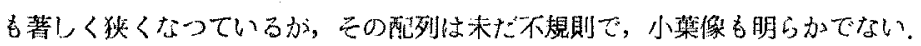

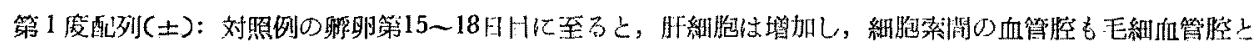

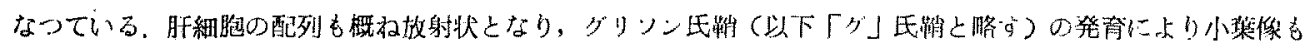
可成り明らか纪なて来ている。

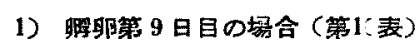

a) 対 照 群

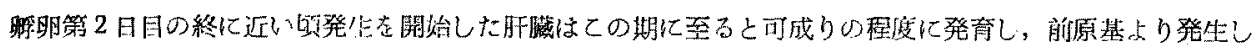
た左葉と，後原基上り発生した右葉之か既に完全に区別出来了.

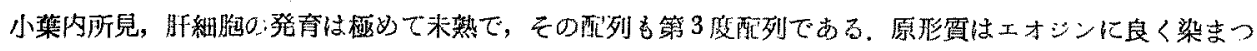

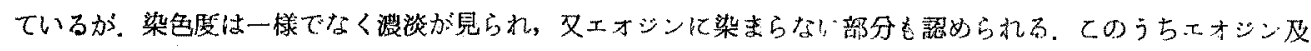

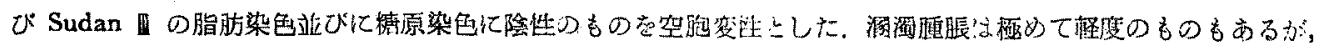

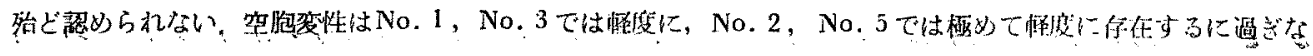




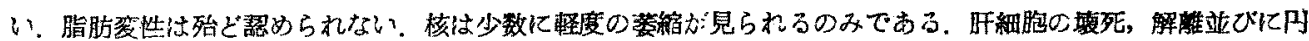

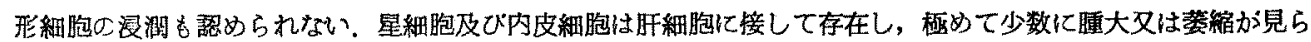

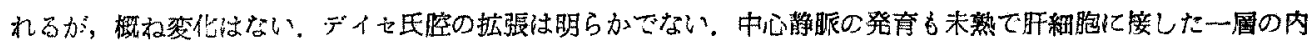

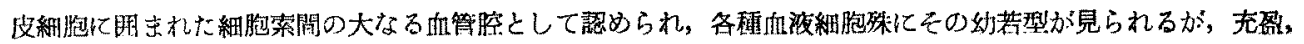

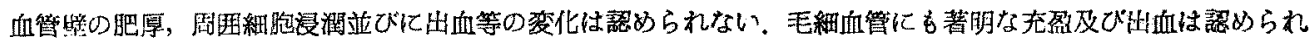
ない.

間質前見，本期に於ては間曾組蟣の発生は未だ認むられない。

b) Nicotine 注 射 例

\section{第 1 群}

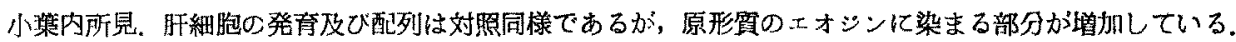

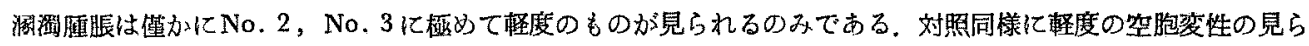

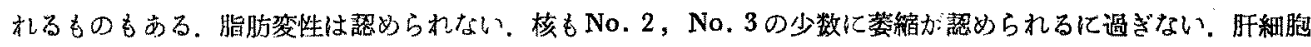

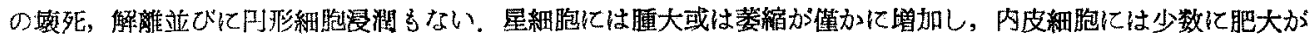

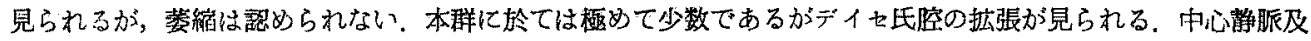

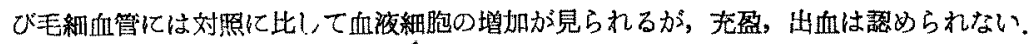

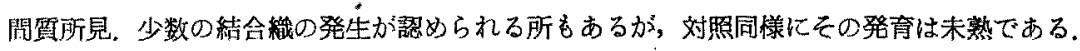

\section{第 22 群}

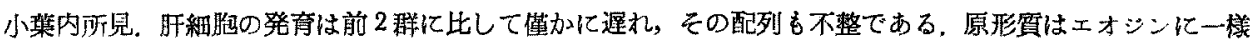

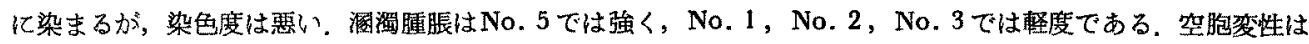

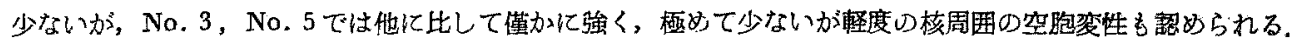
脂肪変性はNo. 5 亿柽度に存在するに過ぎない，核はNo. 5 亿菱縮，䐎化及び消失が見られるが，その他では変

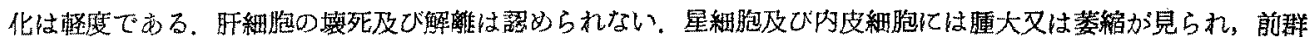

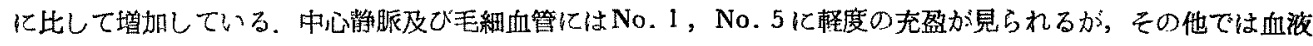

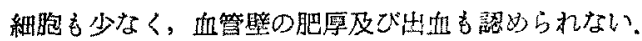

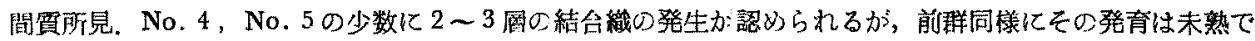
ある。

\section{第 3 群}

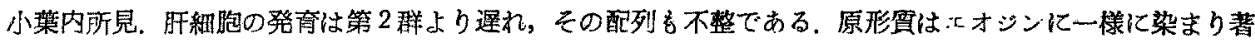

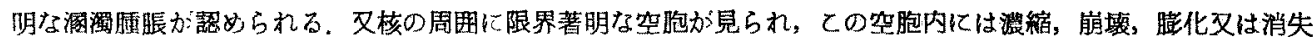

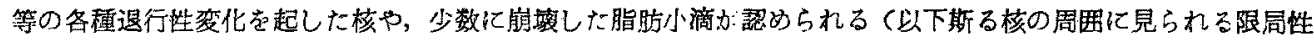

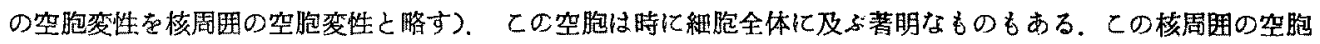

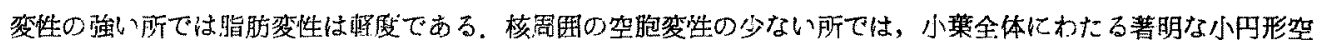

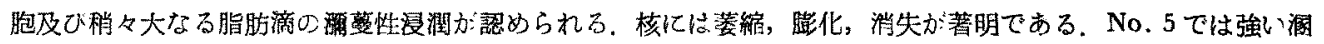

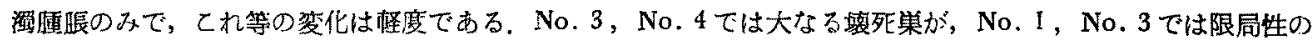

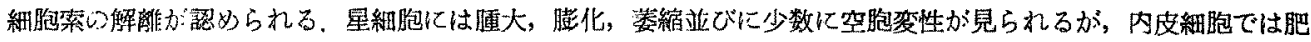

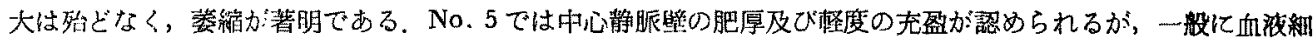

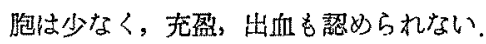

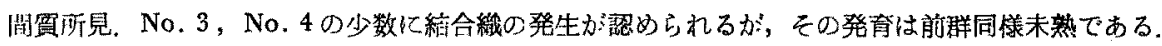

第 4 群

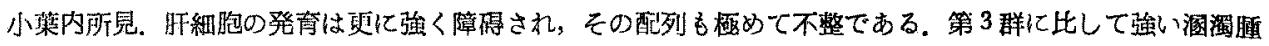

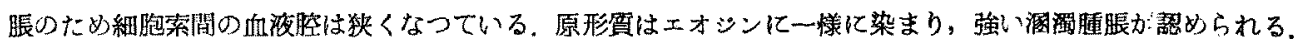

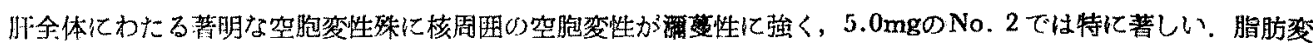

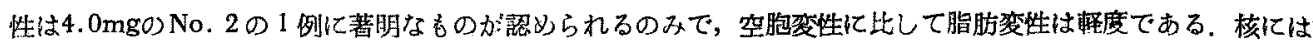

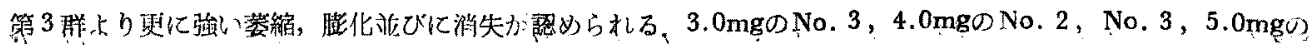




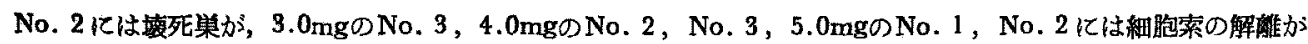

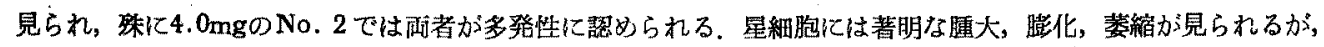

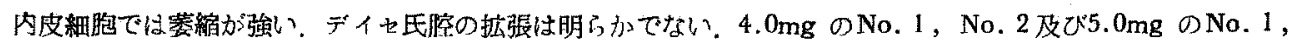

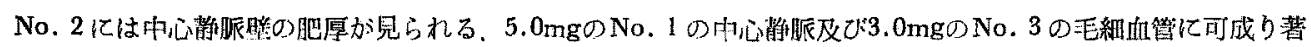

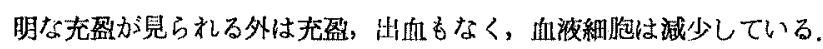

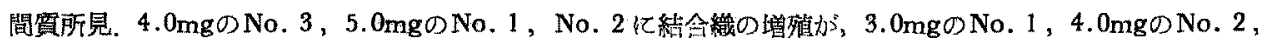

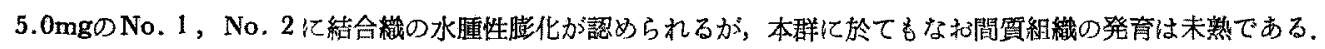

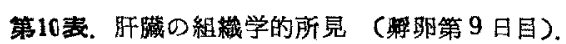

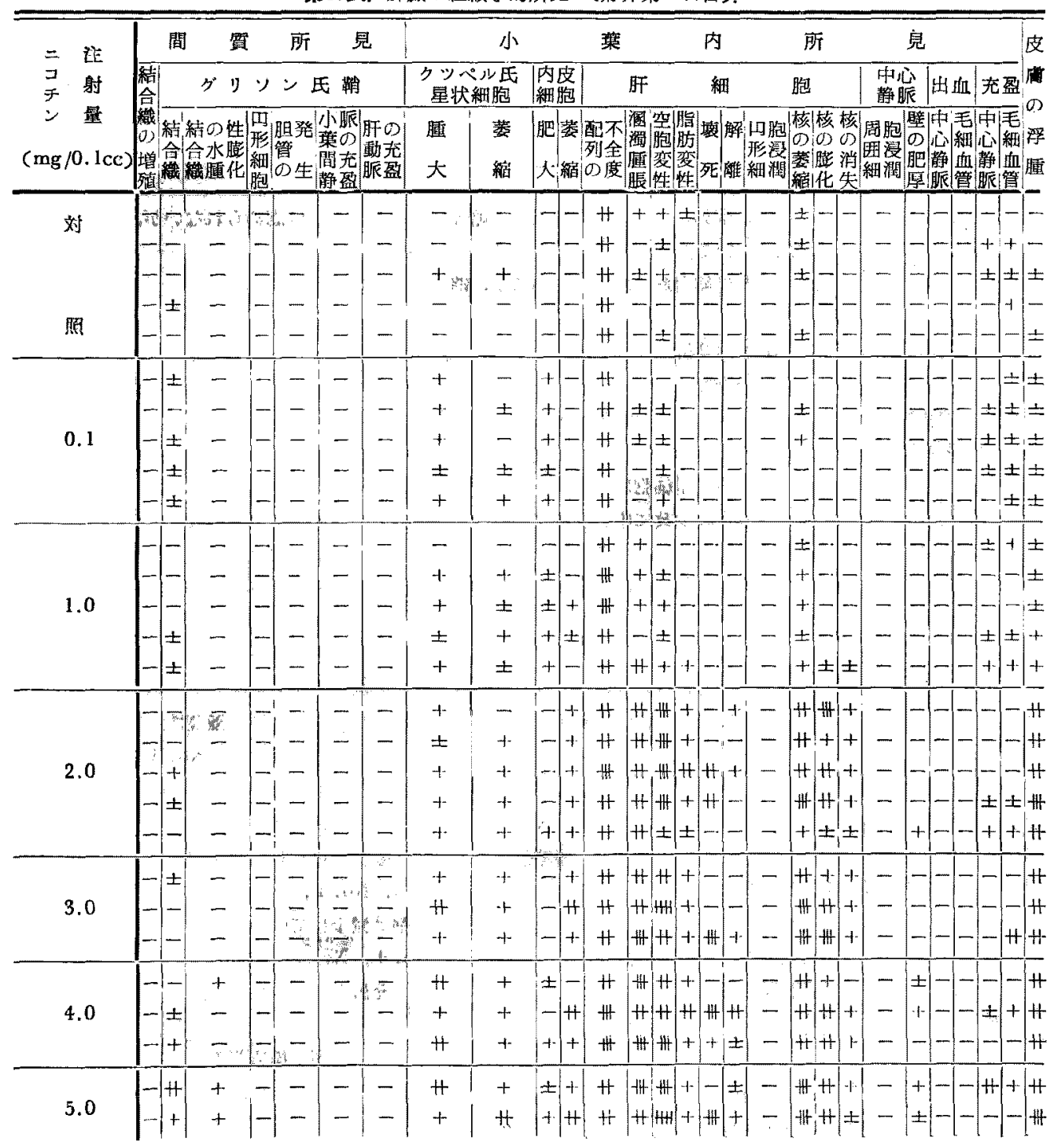

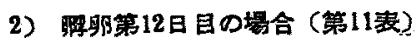

a) 対 照 群 


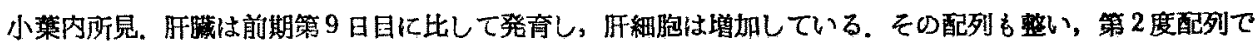

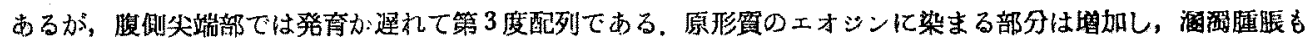

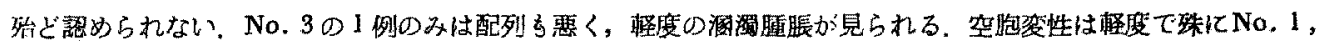

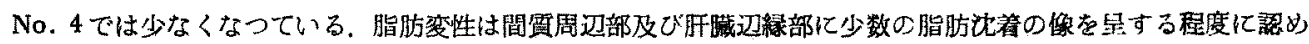

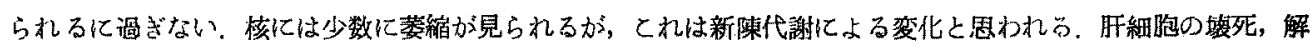

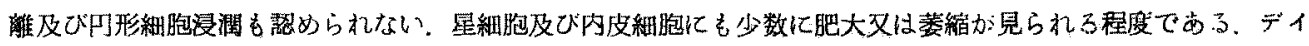
七民膯の昖張も前記同㥞に明らかでない，中心静脈には少数に軽度の充盈力認められるが，血管壁の肥厚，周囲

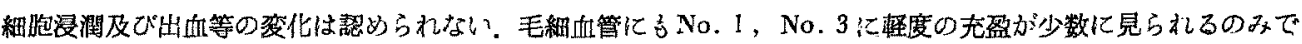
ある.

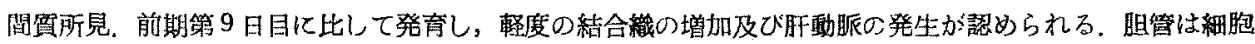

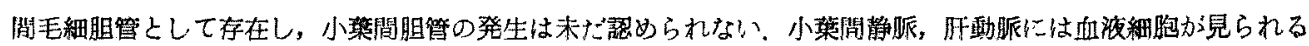
が充盈屿㦘められない.

\section{b) Nicotine 注 射 群}

\section{第 1 群}

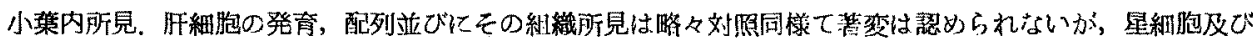
内皮緗盷の耽大加僅加增加している。

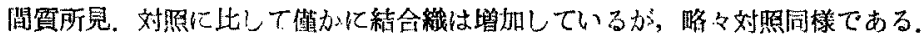

\section{第 22 群}

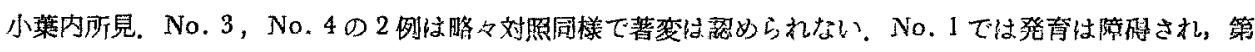

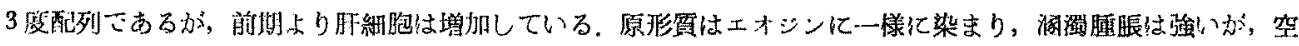

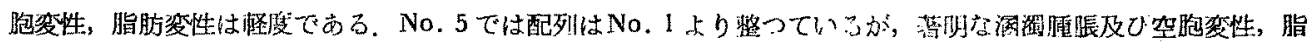

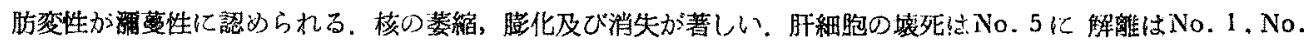

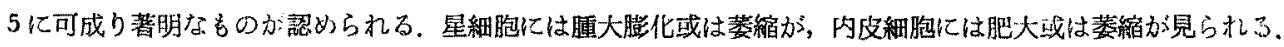

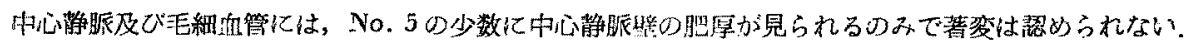

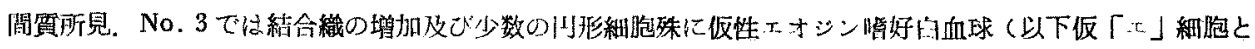

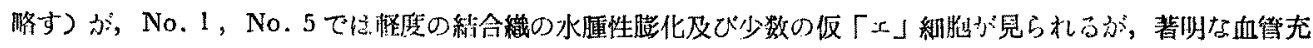

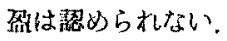

\section{第 3 群}

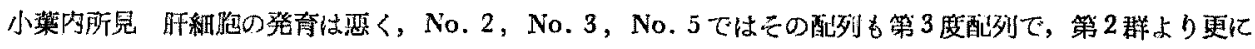

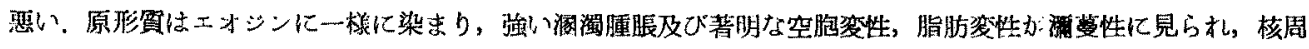

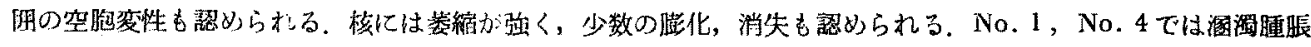

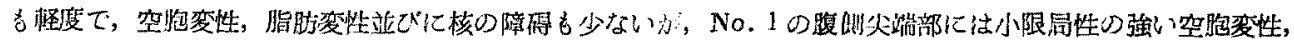

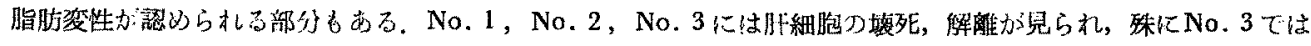

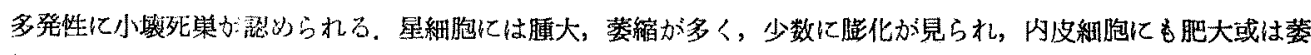

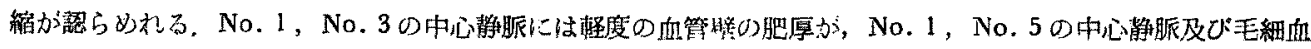

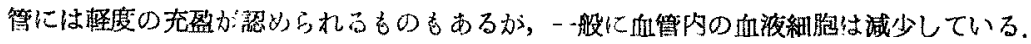

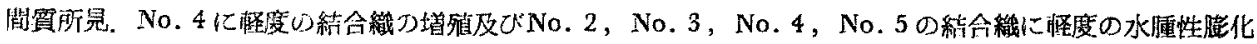

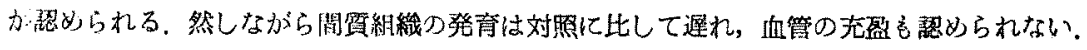

\section{第 4 群}

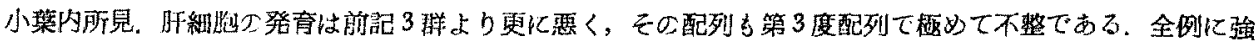

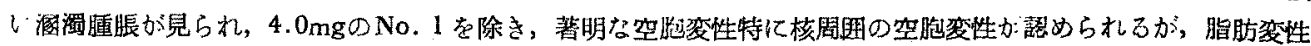

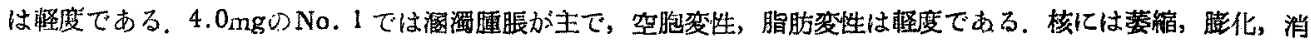

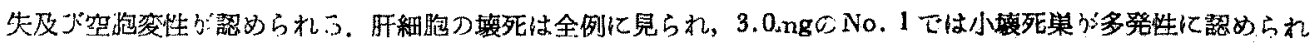

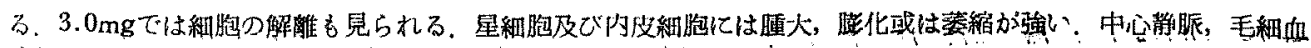


管には3.0mgのNo. 1 亿可成り著明な充臀が見られるが，その他のものでは充盈す柽度のものが少数に認められ るに過ざない，出血は認められない．

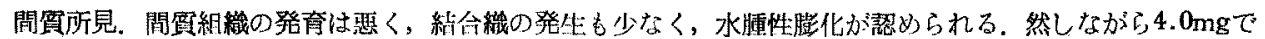

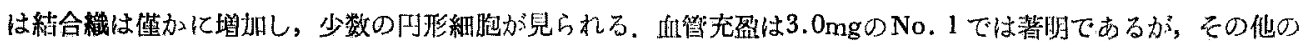
ものでは怪度汃，又は誃ど喼められない。

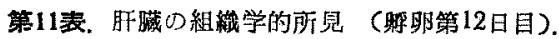

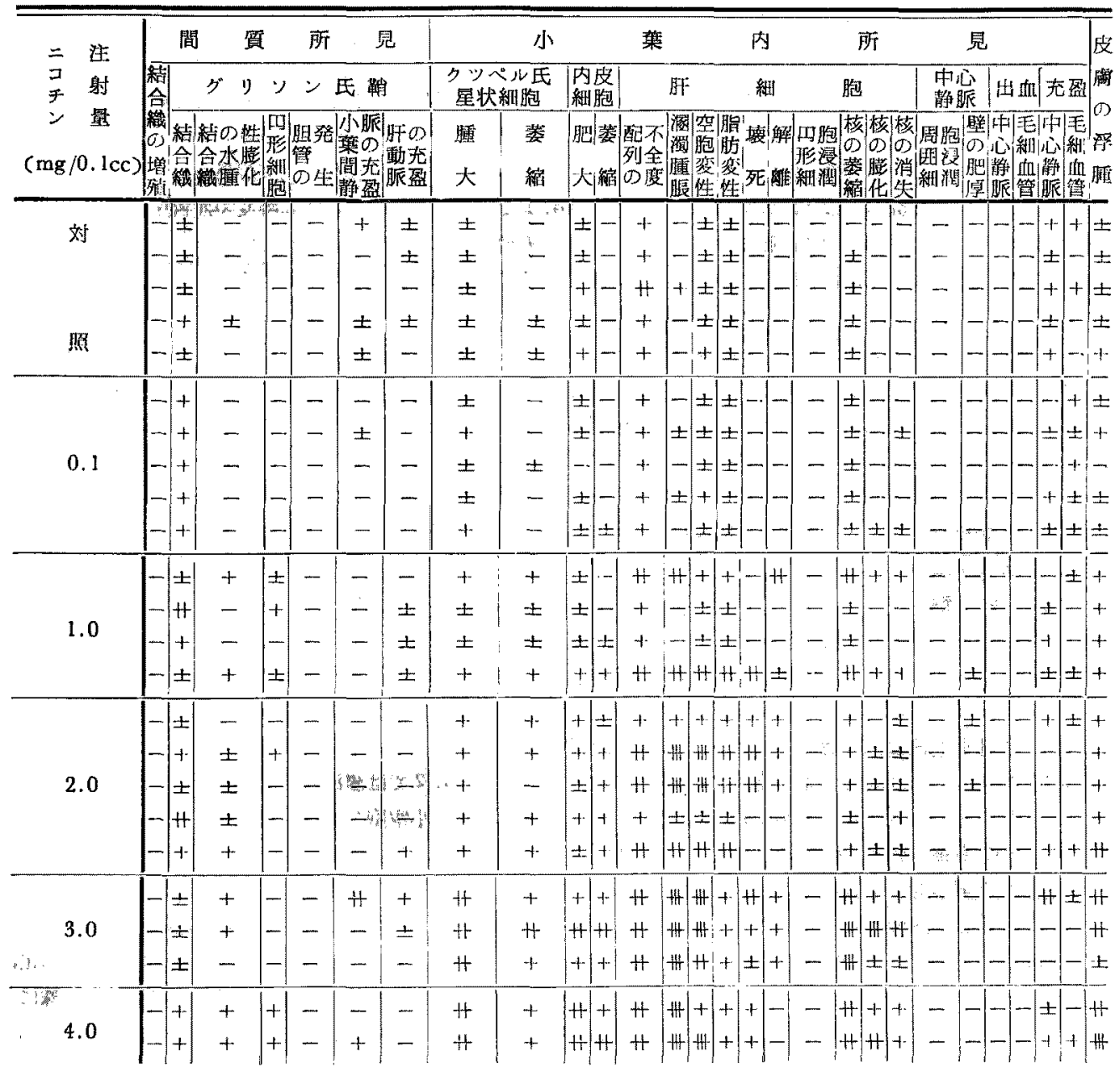

\section{3）䐺䣕第15日目の場合（第12表）}

a) 対 照 群

小葉内所見。旰細胞は前期符12日目に比して更に発育し，実賈の充央が認められる，又朋細胞の発育增殖に

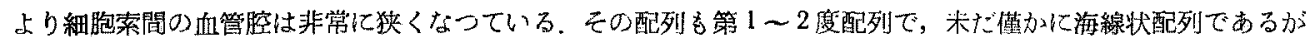

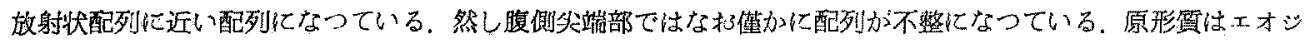

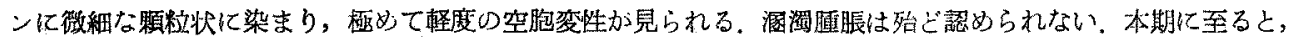

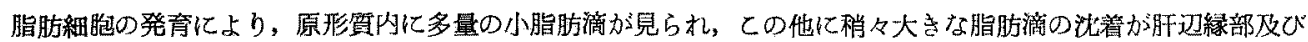

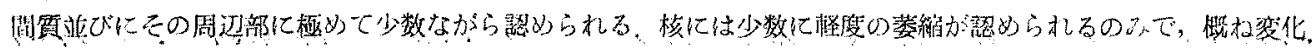




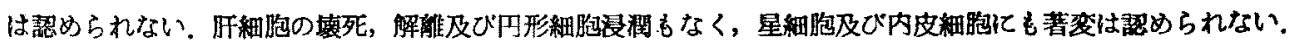

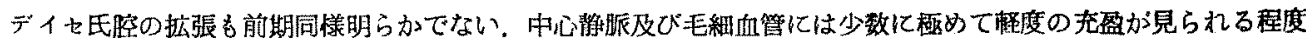
で, 著変は諗められない。

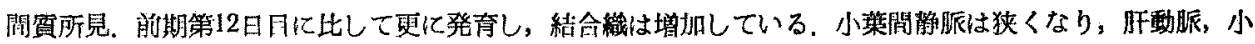

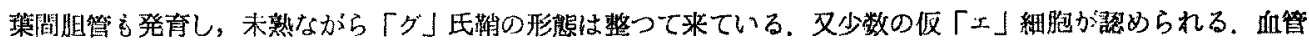
内には各種血液細胞が晃られるが，充盈は認められない。

\section{b) Nicotine 注射群}

\section{第 1 群}

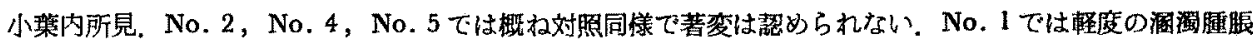

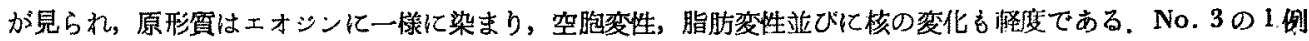

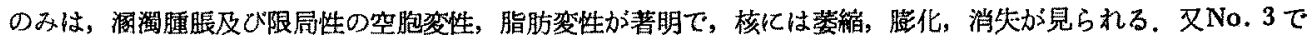

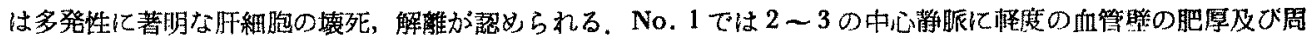
国紐胞浸湖が，No. 3 では中心静脈及び毛細血管の柽度の充盈が琵められる。

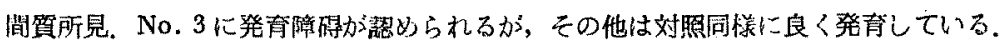

第 2 群

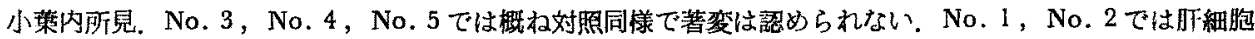

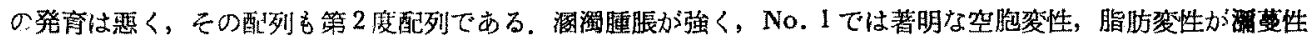

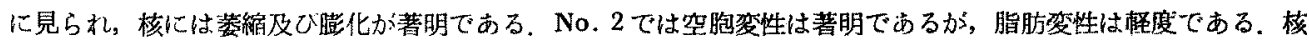

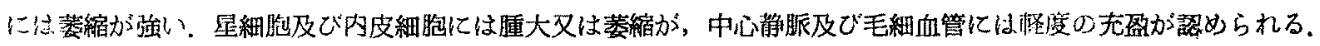

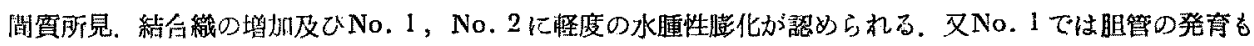

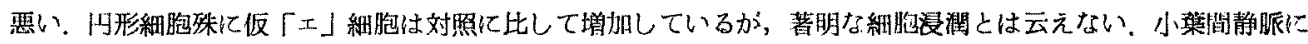
は柽度の无盈が㒛められる。

\section{第 3 群}

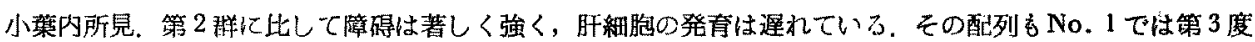
配列に近く，No. $3 ，$ No. 4 では第 2 度配列であるが，限局性に配列の乱れた所が認められる部分もかる。. No.

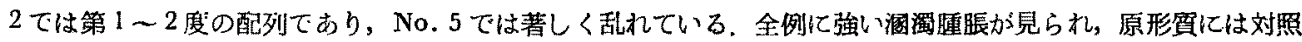

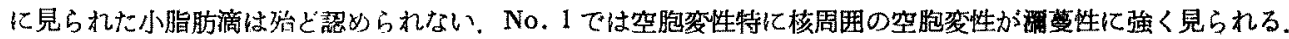

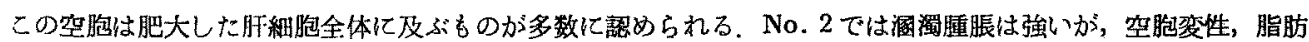

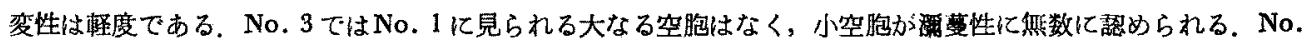

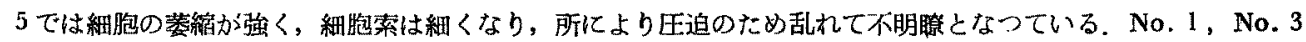

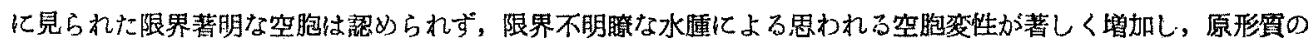
エオシンン染まる部分は橄妙て少ない．No.4ではNo.1，No. 3，No. 5 に見られる変化が混在している，即

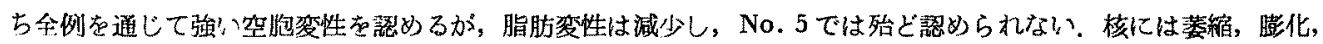

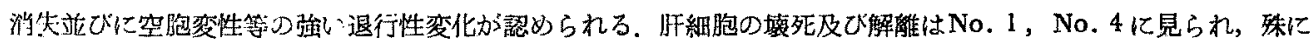

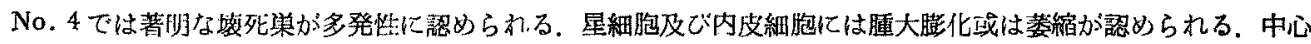

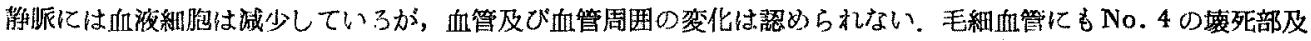

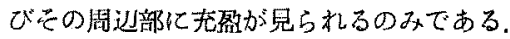

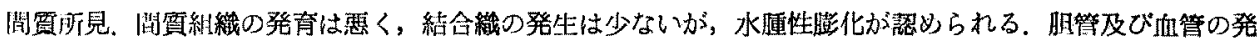

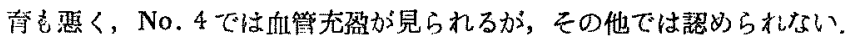

\section{第 4 群}

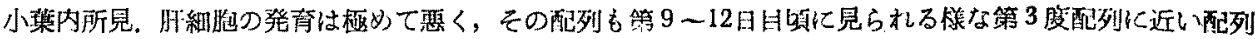

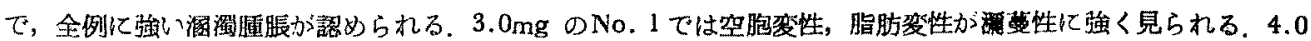

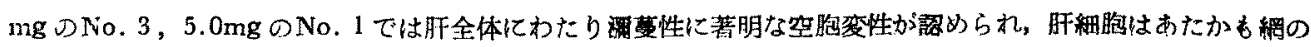

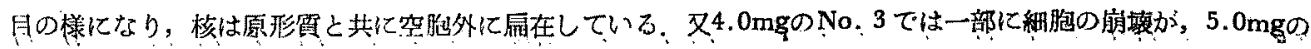


No. 1 では局所性の空胞変性，脂肪変性の浸潤が見られる. 空胞変性の強い所では脂肪帘性は始ど認められなく なつている. 5.0mgのNo. 2, No. 3では原形貧はエオシンに一㥞に強く染まり，空胞変性，脂肪変性す軽度て

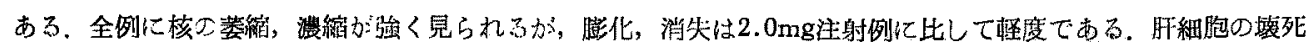
及び解離は3.0mgつNo. 1，4.0mgのNo. 3，5.0mgの全例に見られ，殊飞3.0mgのNo.1では大なる壊死栄が

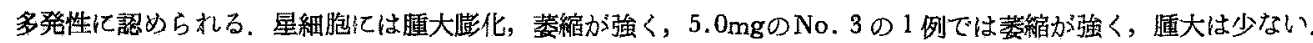

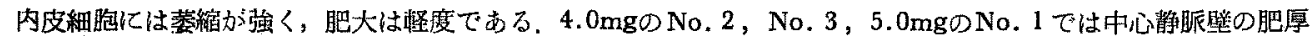
が, 4.0mgのNo. 3, 5.0mgのNo.1 では中心静脈及及び毛細血管の充盈が強く，その他では少数に怪度の充盈 が認められる程度である。

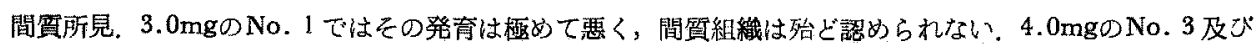

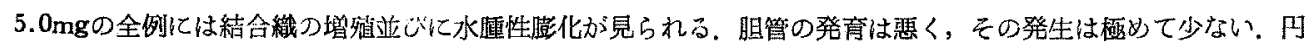

第12表，肝缄の組識学的所㫕 (躬卵第15日目).

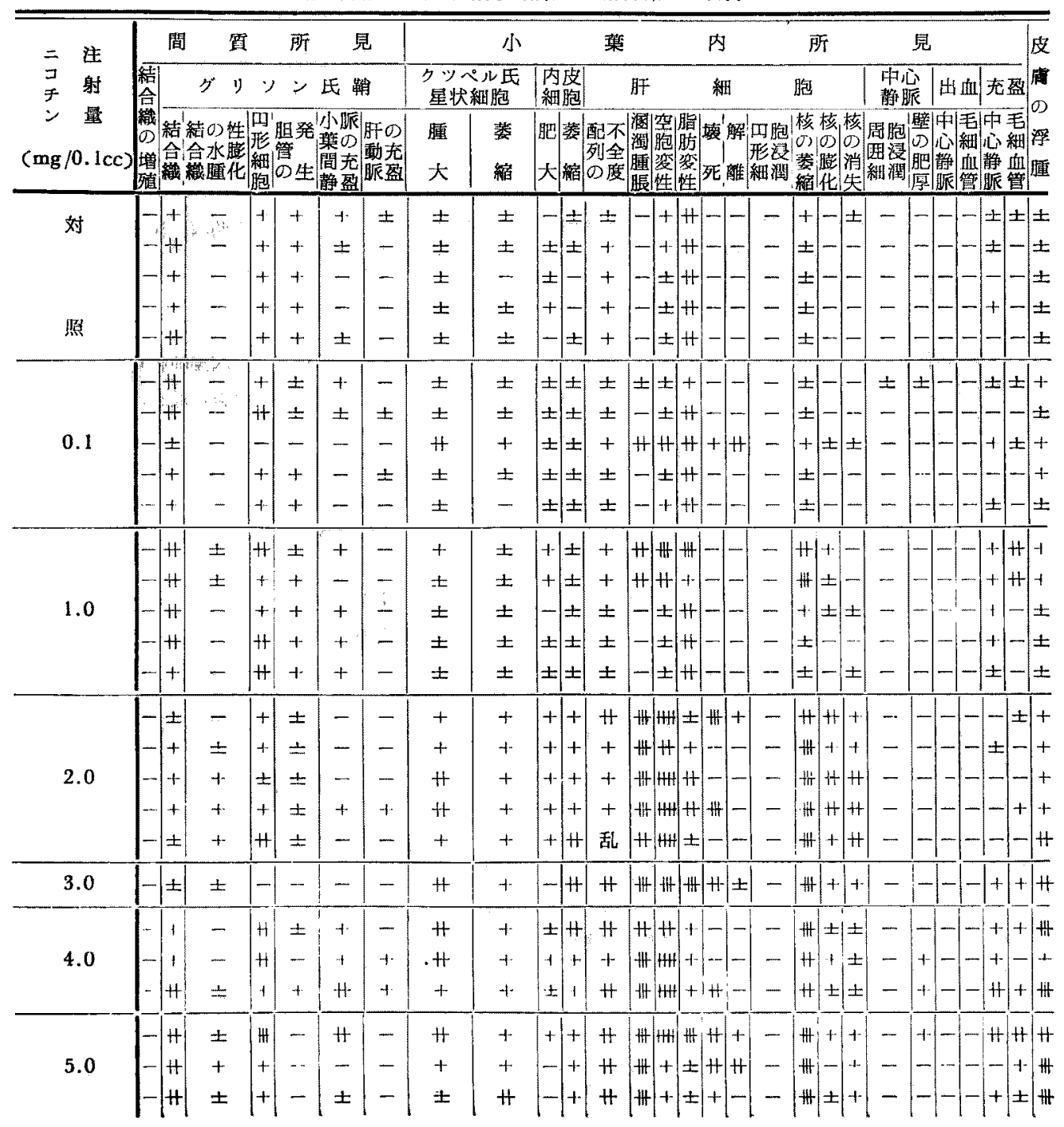




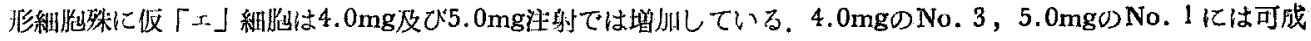

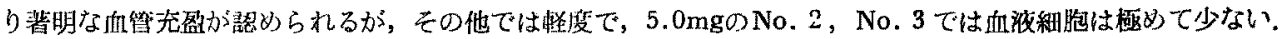

\section{4) 䣙卯第18日目の場合 (第13表)}

a) 対 照 群

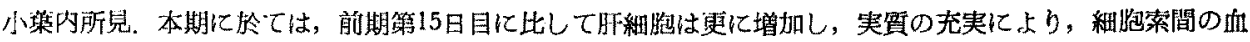

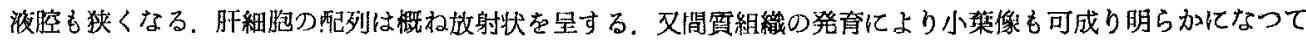

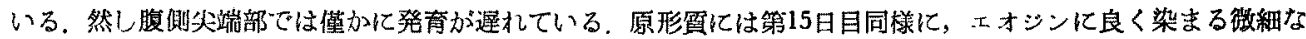

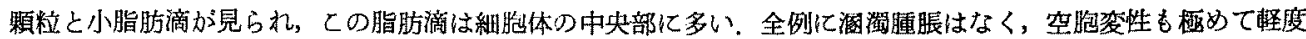

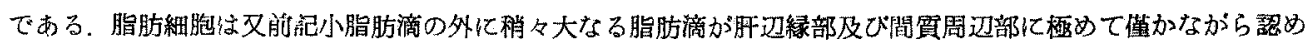

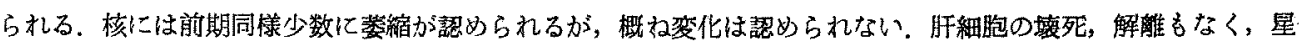

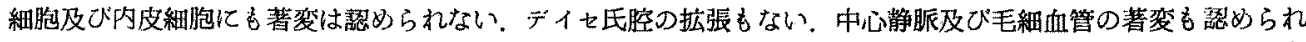
ない.

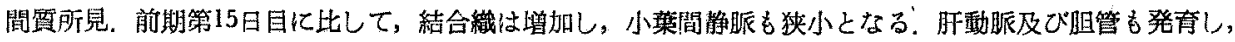

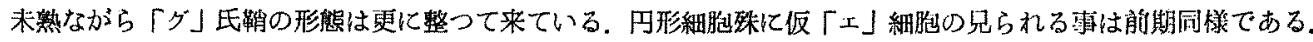

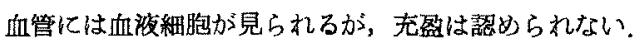

\section{b) Nicotine 注 射 例}

\section{第 1 群}

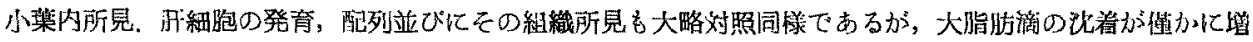

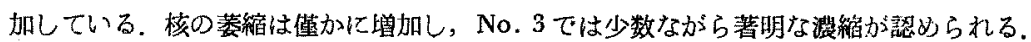

間賈所見。概ね対照同様で著変は認められない。

\section{第 2 群}

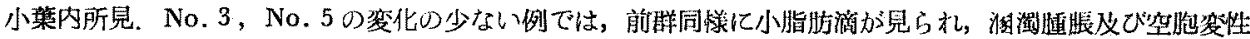

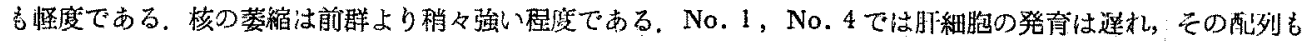

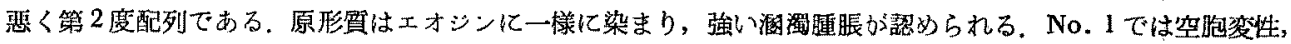

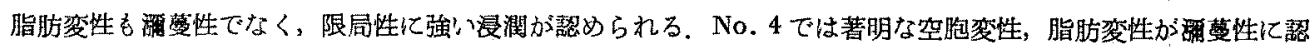
められる，核には萎縮が強く，少数に膨化及び消失が認められる，又細胞索つ解離が認められる，星細胞には埂

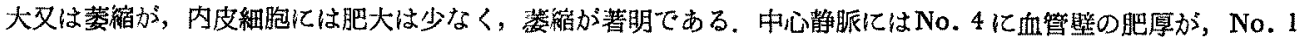

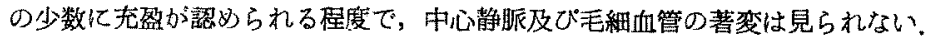

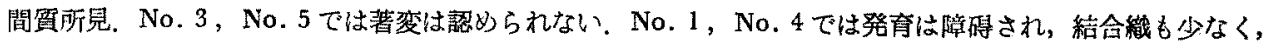

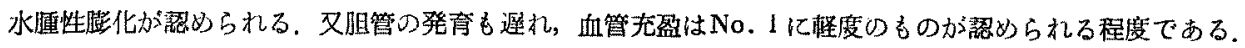

No. 2 の中等度水腫例では2.0mg注射の中等废水腄例と同様な変化が見られるので第 3 群に於て述心゙る。

\section{第 $\mathbf{3}$ 群}

第 3 群に於ける変化は多栏のため，皮虔の変化に従つて次の如く分類した。

\section{No. 1 の軽度浮腫洌}

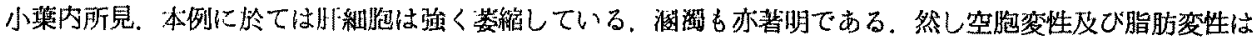

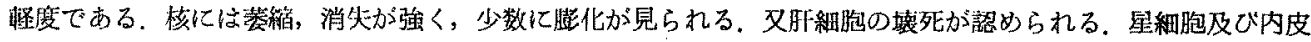

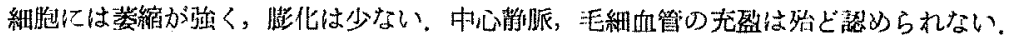

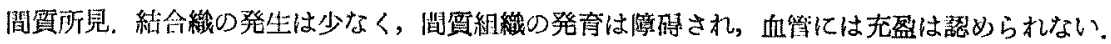

\section{No. 2. No. 4及び1.0mg の No. 2の中等度水腫例}

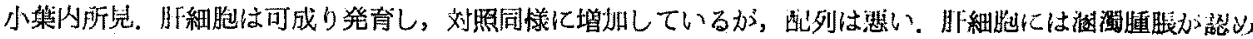

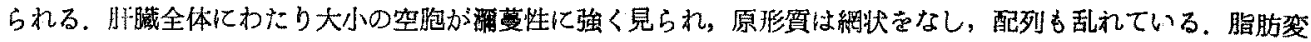

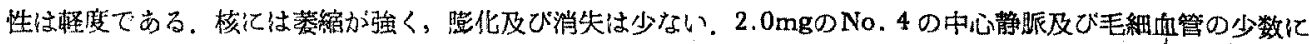

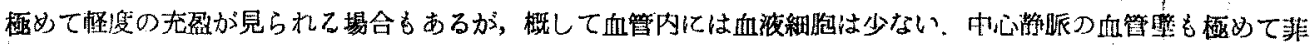

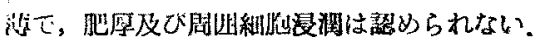




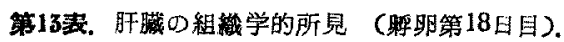

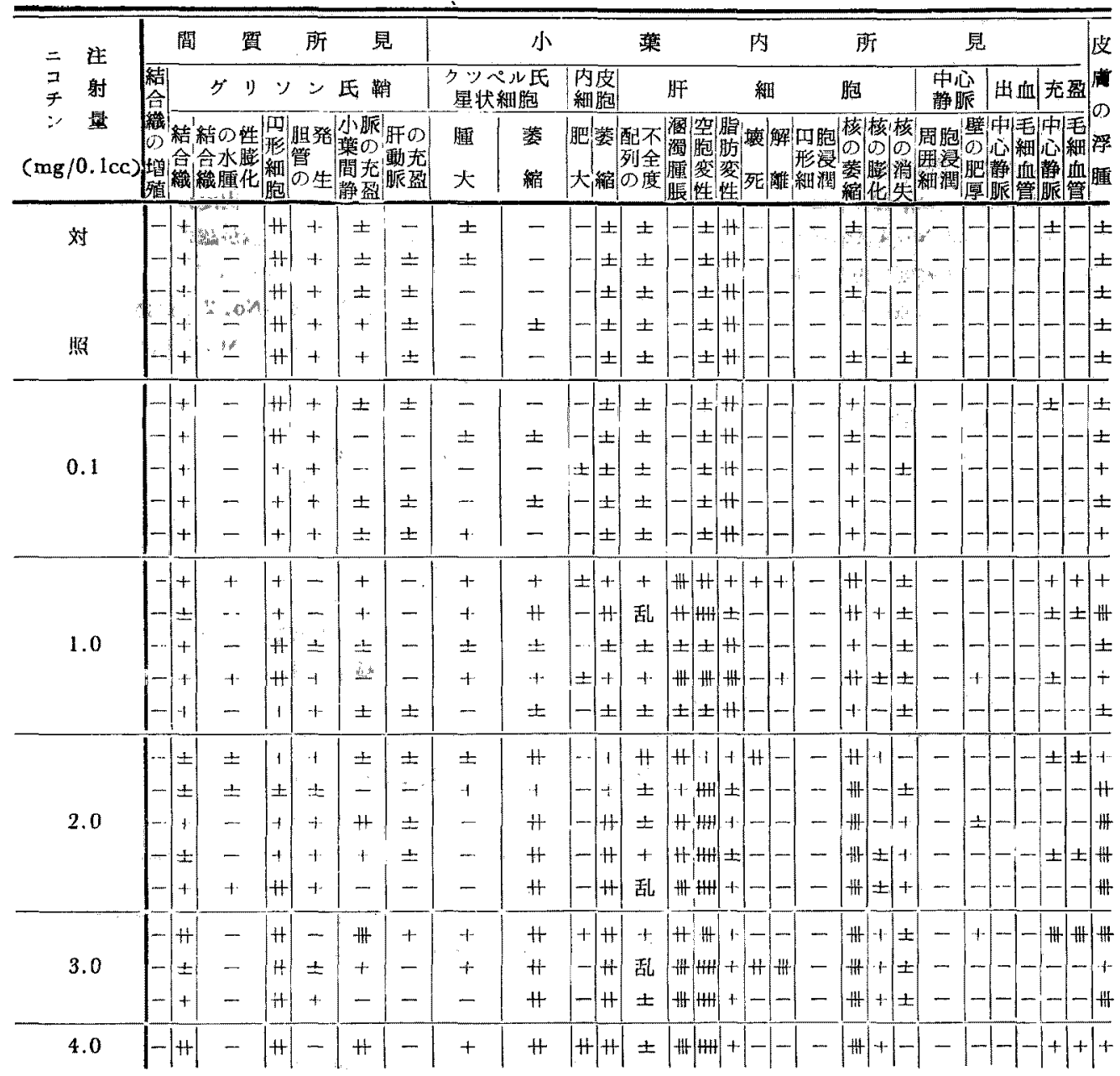

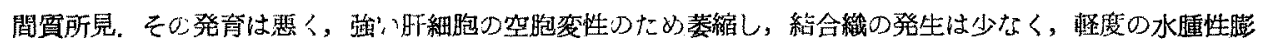

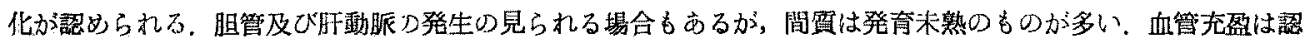
めらtいl.

No. 3. No. 50 高水腫洌

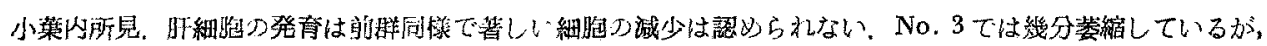

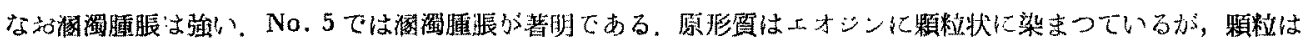

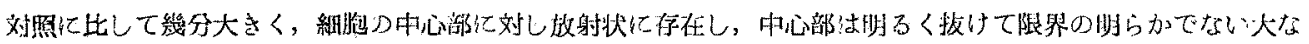

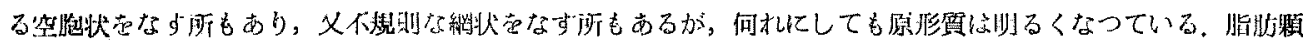

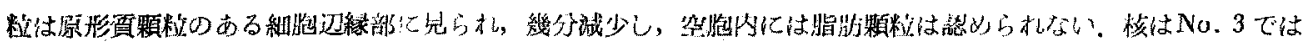

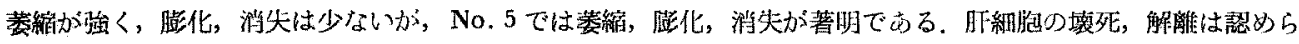

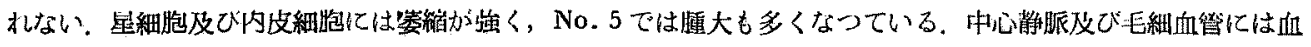
洨細胞は少ない。

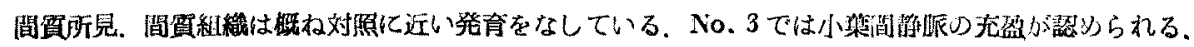


第 4 群

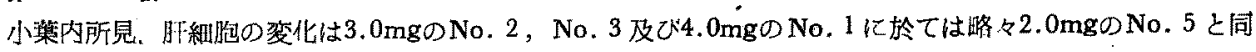

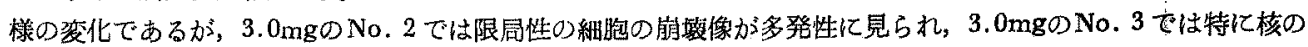

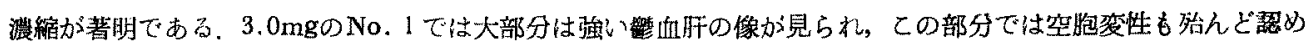

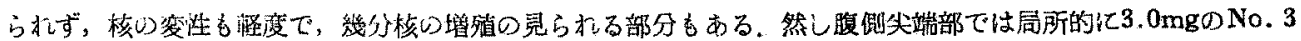

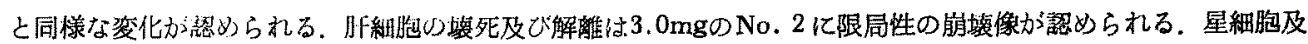

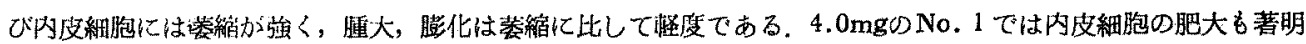

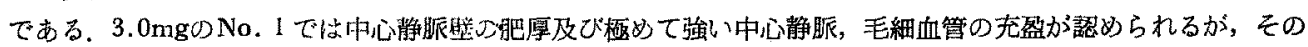

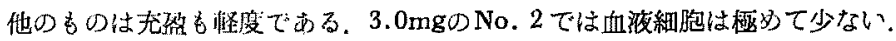

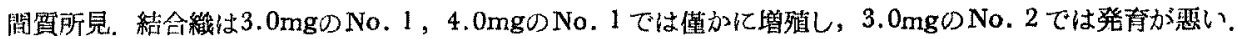

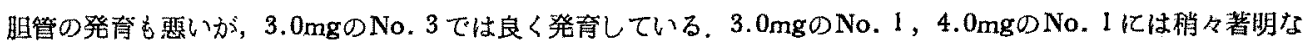
血䇾无䀀が琶められるが，3.0 mgのNo.3では血液細胞は極めて少ない.

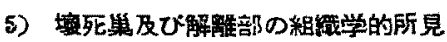

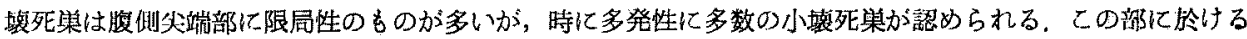

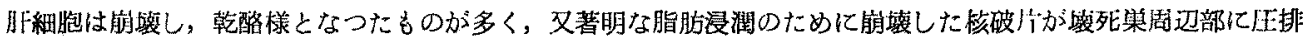

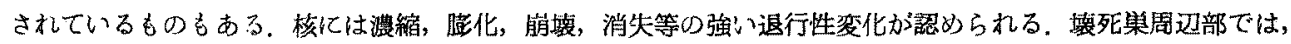

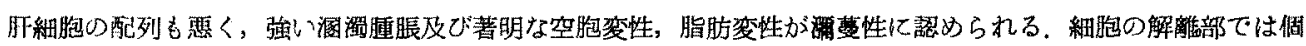

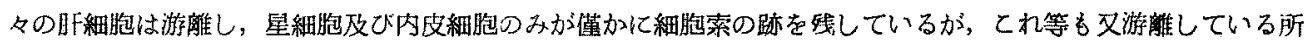

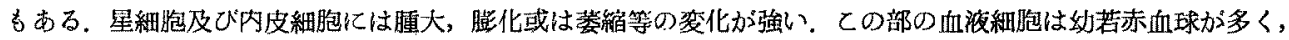

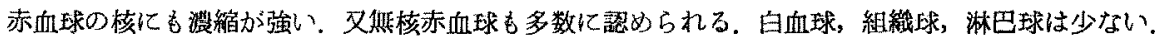

1V. 水腫洌に於けるその他の器の变化

1) 肉眼的所見

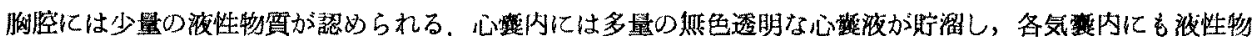
唄が部められる。

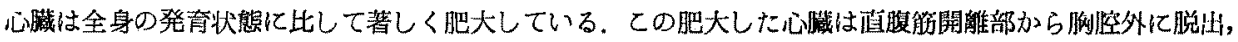
心整を被つたまま水腯腔内に桇出し，明らかな心搏動が透見されるものもある。

肺藏の肉腿的な変化は明らうでない。

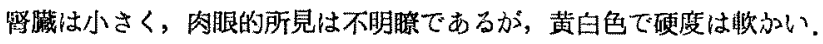

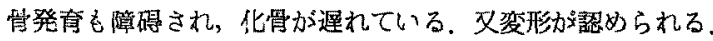

2) 組織学的所見

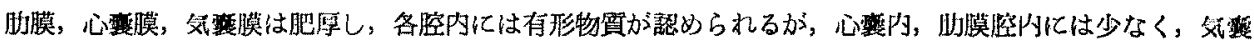
队には著しいものかうむる。

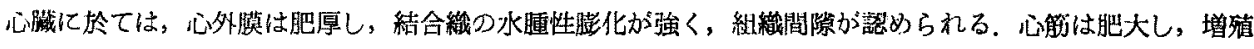

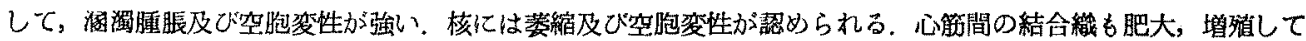
いる.

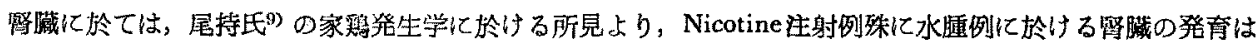

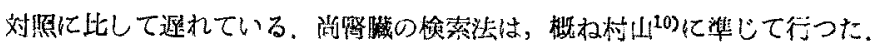

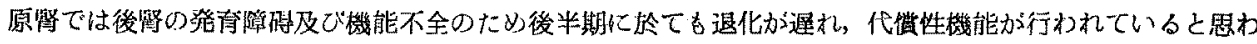

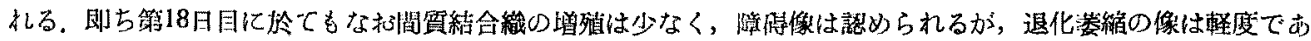

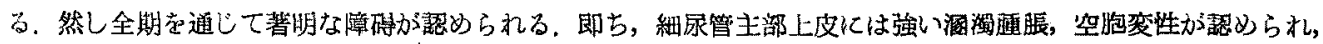

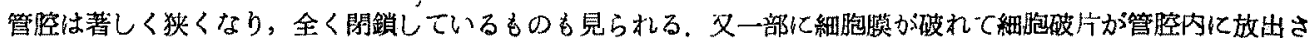

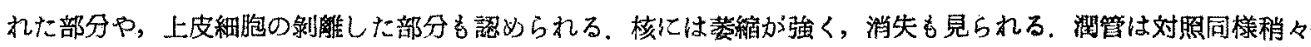

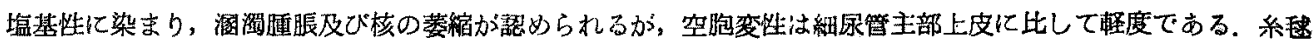

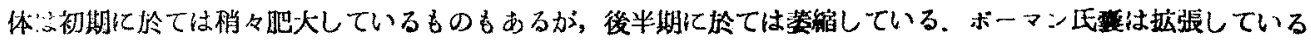




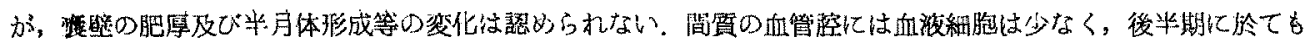
結合織の增殖は㷫妙られない。

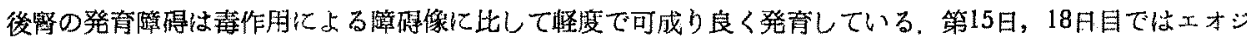

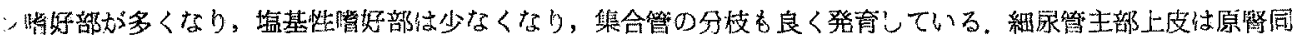

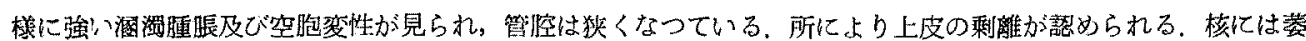

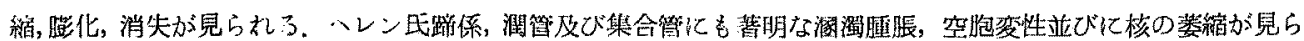

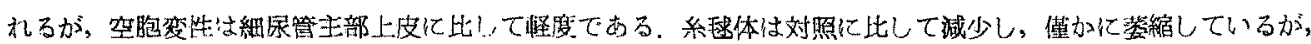

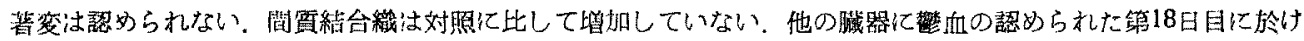

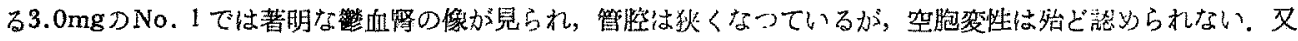
間質組織の增雅をない。

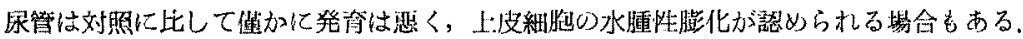

\section{総括並びに考按}

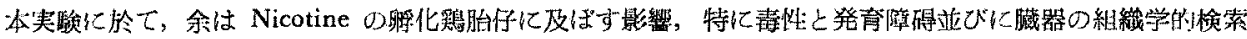

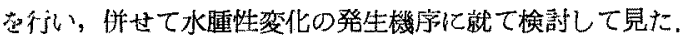

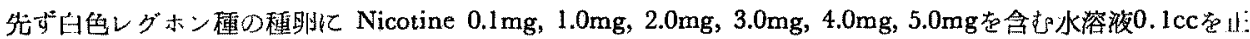

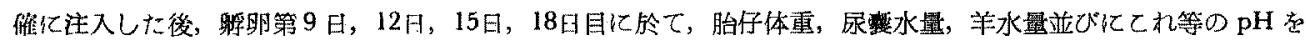
测定した。次で発育状態並でに畸形觉観察し，死亡月卵の有然に就て検討した。

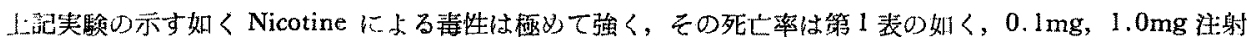
では対照に比して高いが，後半期に於て坟対照同様に死亡眀は少くなつている．然るに2.0mg注射では第12日日 は $34.2 \%$ ，第15日目は $57.9 \%$ ，第18日目は71.9\%となり，第12日目以降に至つて急激高くなつている。更に3.0

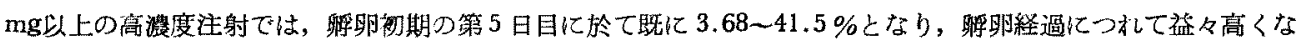

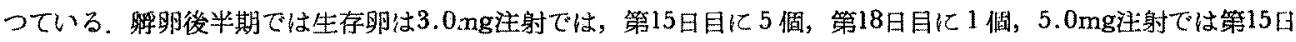
目に 2 個が得られ，4.0mg注射の第15日目及び5.0mg注射の第18日目には生存畉は得られなかつた。 又これ等の

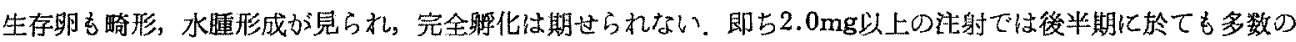

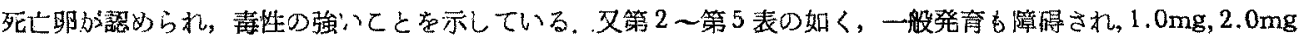

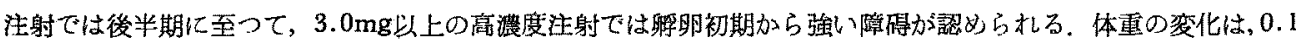

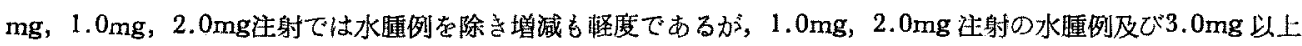

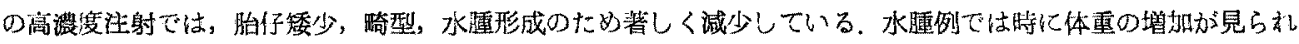

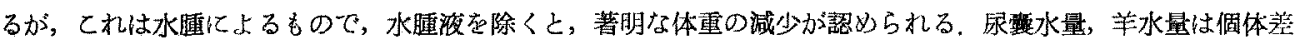

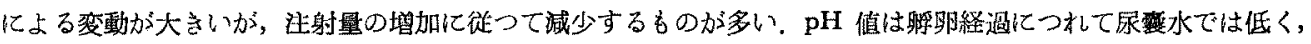

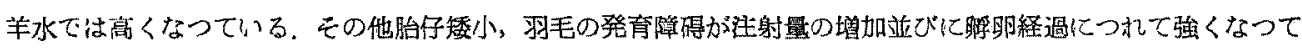

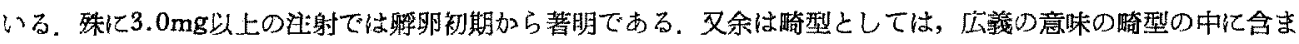

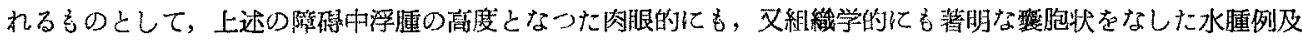

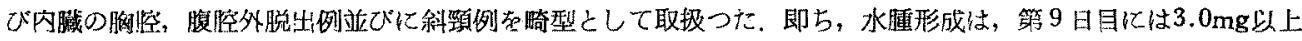

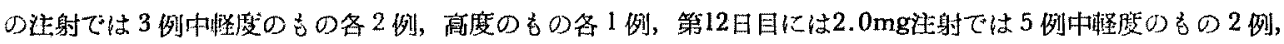

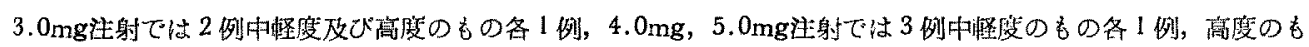

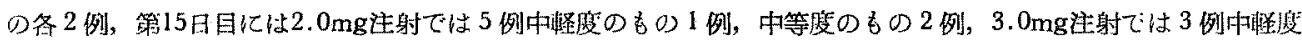

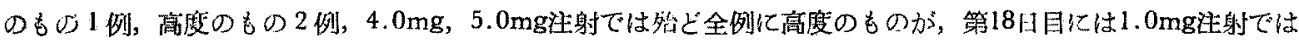
5 例中怿度及び中等度のもの各 1 例， $2.0 \mathrm{mg}$ 注射ては 5 例中中等度のもの 1 例，高度のもの 2 例, $3.0 \mathrm{mg}$ 注射で

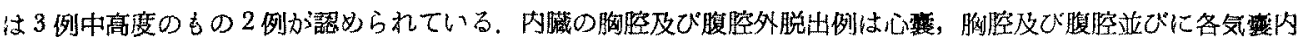

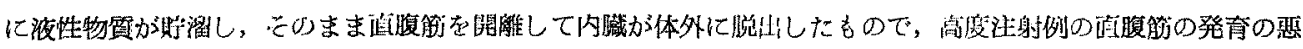

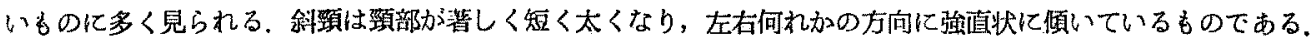

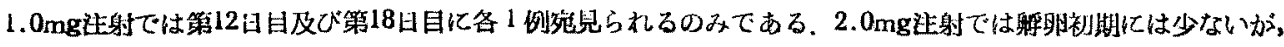




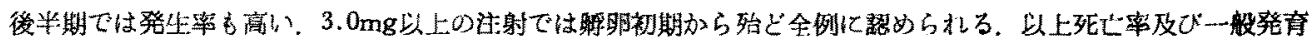

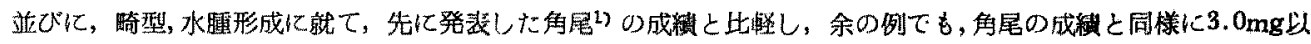
上の注射では全期を通して，2.0mg注射では後半期に至って高い死亡率及じ畸型殊に水腫形成か認められだ. 又

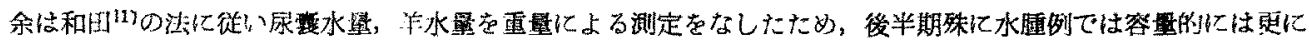
減少心著しい白のが多い。

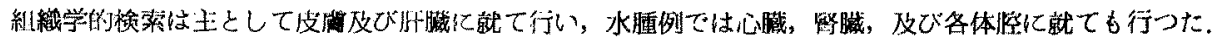

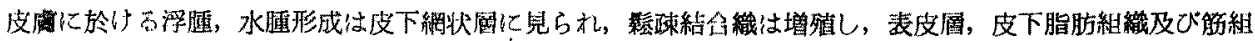

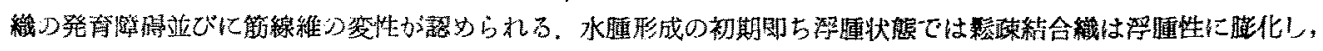

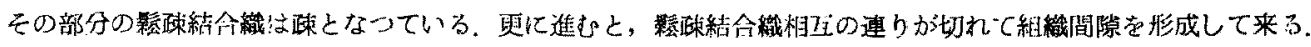

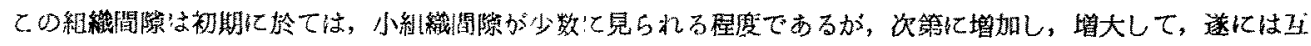

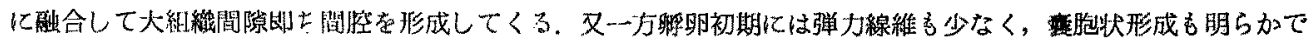

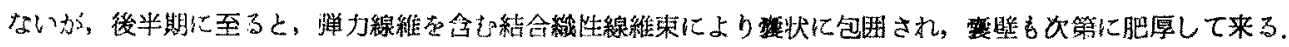

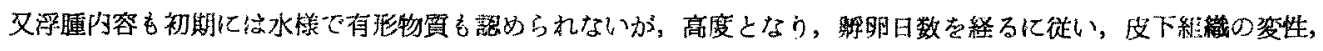

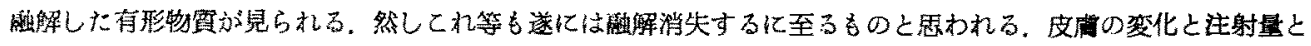

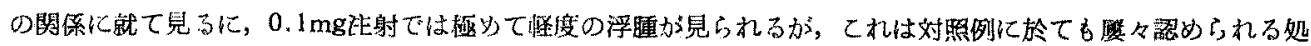

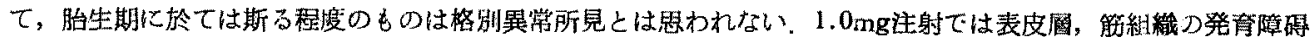

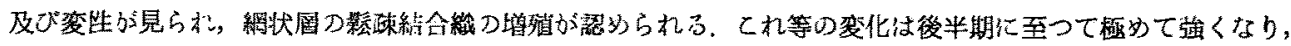

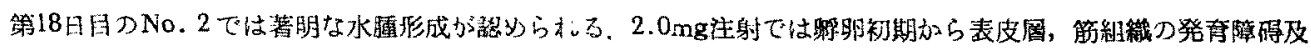

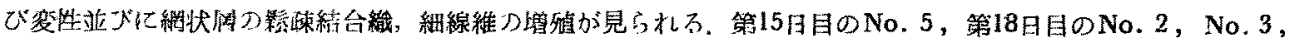

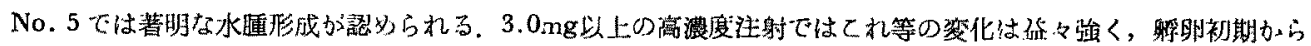

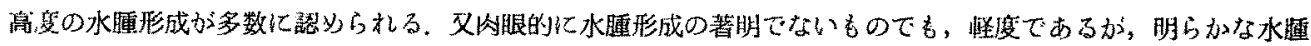

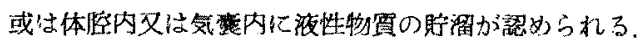

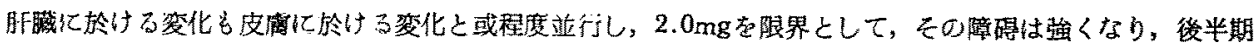

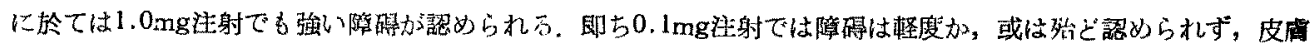

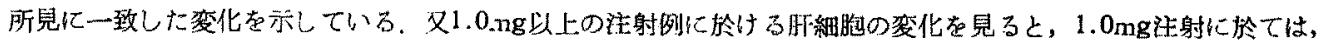

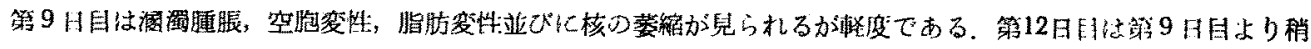

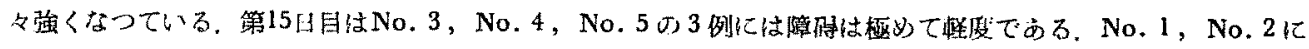

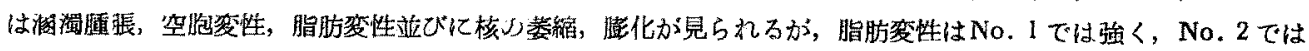

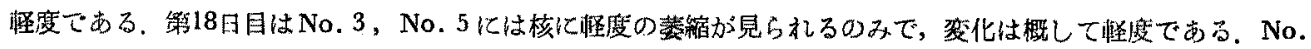

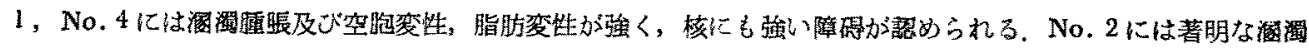

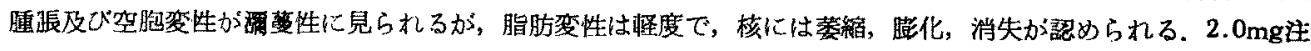

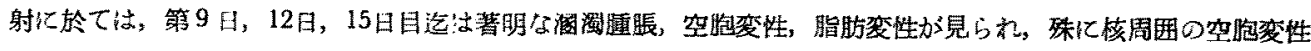

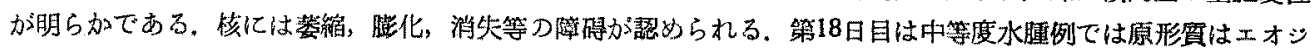

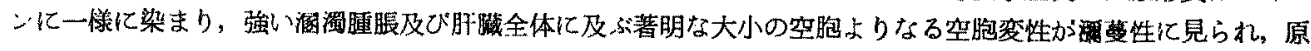

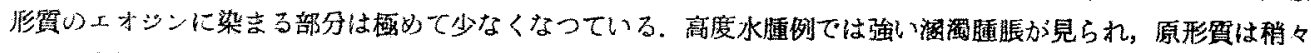

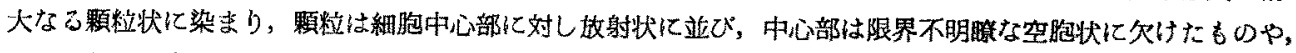

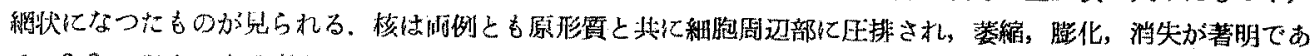

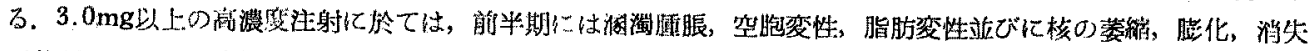

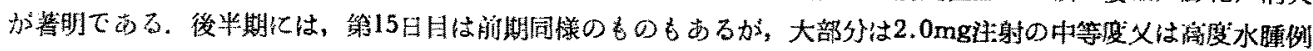

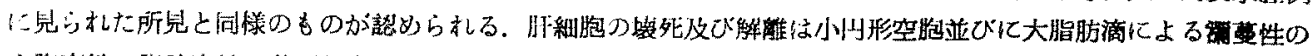

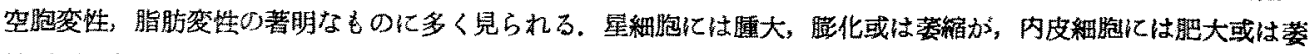

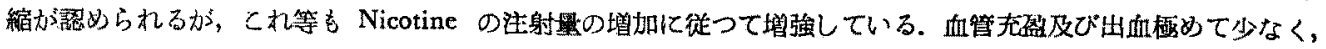

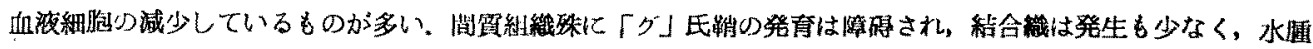

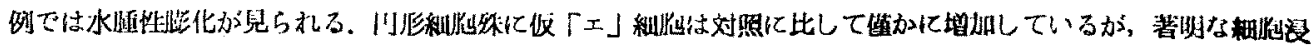




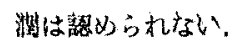

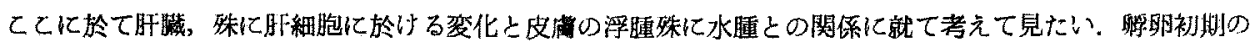

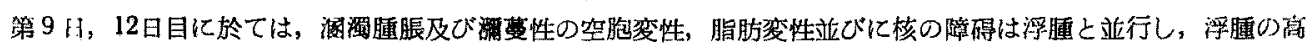

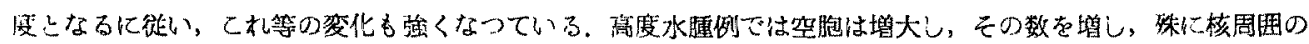

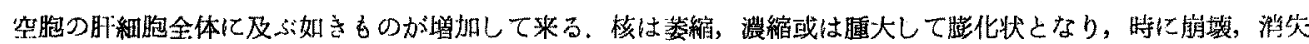

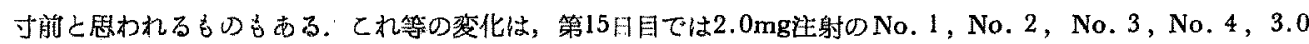
$\mathrm{mg}$ 注射のNo. 1，4.0mg 注射のNo. 3，5.0mg注射のNo. 1 の睡度水睡例及び中等度水嗹例に，第18日目では

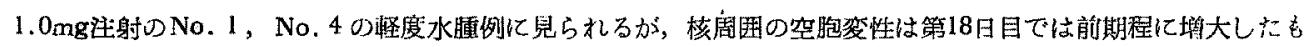
のはなく，その数も少ない．第 15 日目の $2.0 \mathrm{mg}$ 注射のNo. 5 及び第 18 日目の $1.0 \mathrm{mg}$ 注射のNo. $2,2.0 \mathrm{mg}$ 注射の

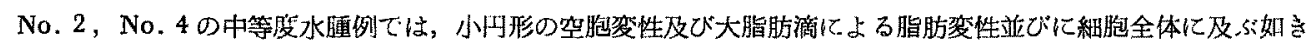

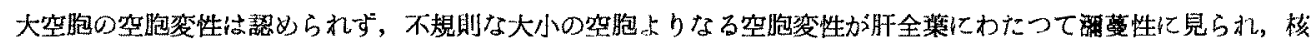

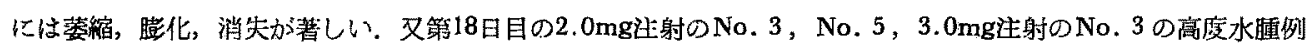

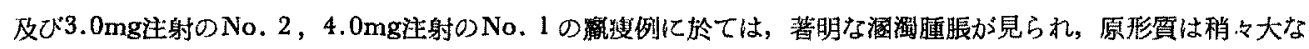
る顆粒状に染志り，顆粒は細狍中心部に対して放射状に立ひ，中心部は限界の明らかでない大なる空胞状となり，

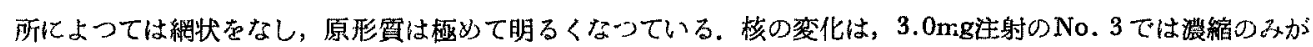

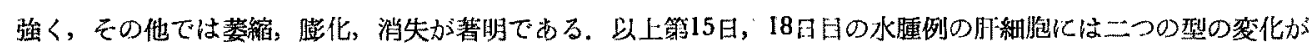

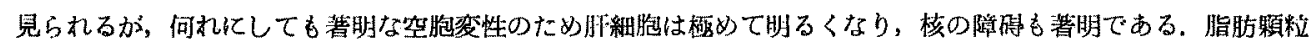
は幾分隇少している。

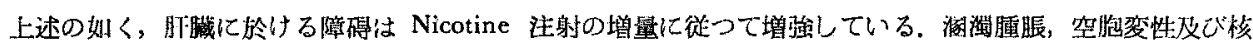

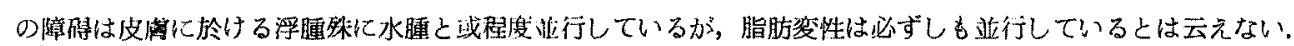

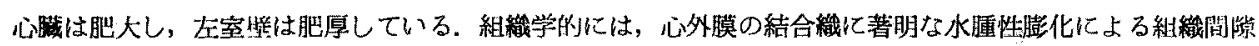

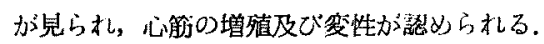

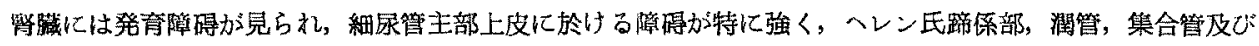

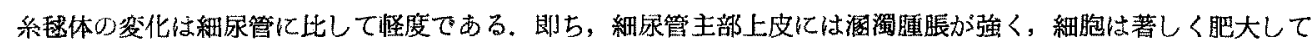

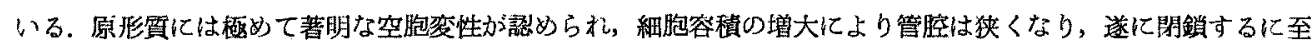

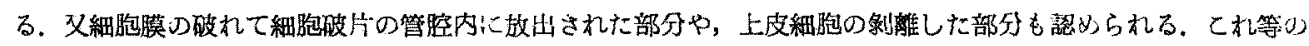

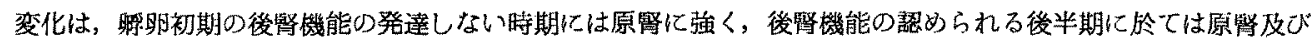

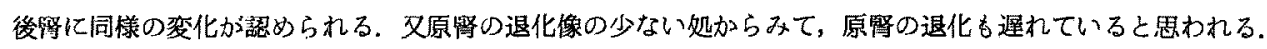

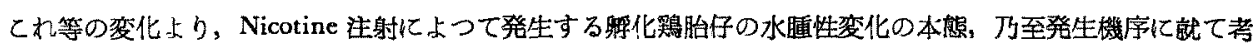
祭するとさ，今日の細胞化学の知識を以て，ての問題を解決するととは至難であつて，臆測つ域を出ない所が多 分にあると思われる.

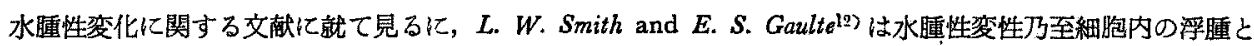
呼ばれるこの変化は，何等汃の因子により力学的に，神経性に或は又炎症の結果循環障捋が起るためか,，或は又

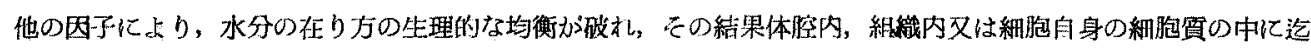

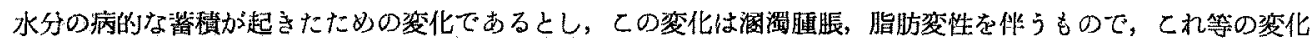

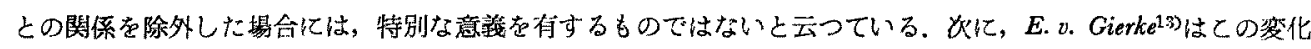

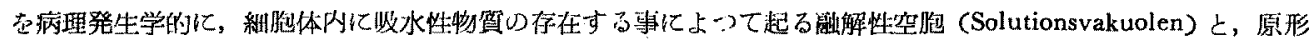

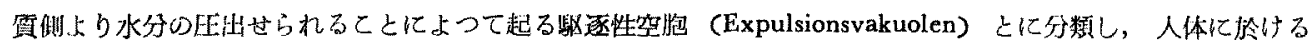

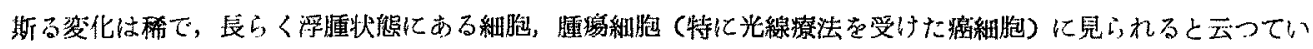

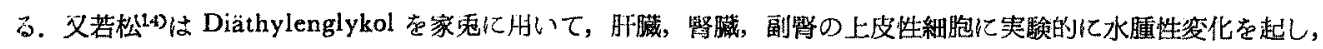
他方 Äthyläther 及び Isoamyläther によつては水瘇性変化の裙められるい処加ら，エーデ基及ぴアルコール 性OHによる細胞膜のリポイト頁の洛解の起るためのものではなく，薬物の直接作用による細胞膜の透過性障碍

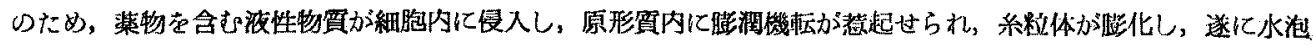
样被状体と化したるのであると云つている。 


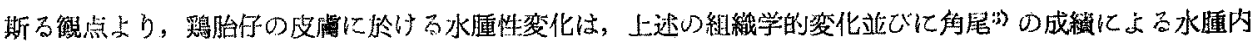
容に Nicotine の存在の琶妨られない等加ら Nicotine の点接作朋によるものではなく，又全身の炎在性変化の軽

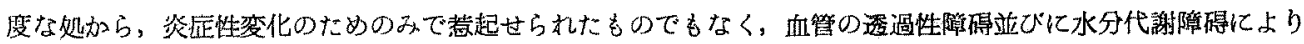
㟟起せられたものと思われる。

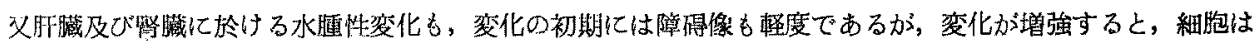

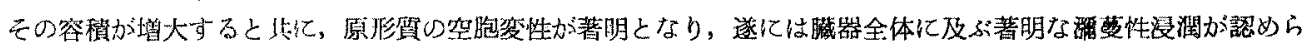

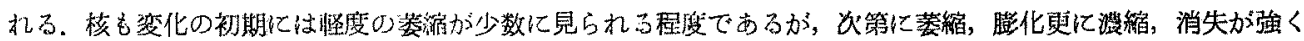

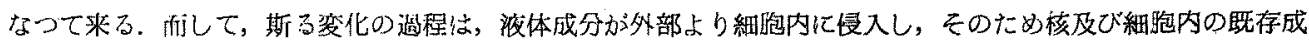

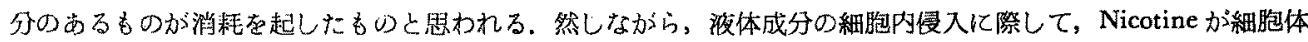

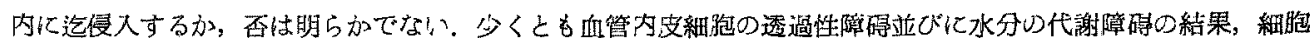

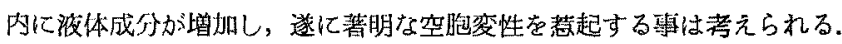

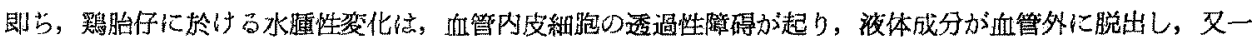

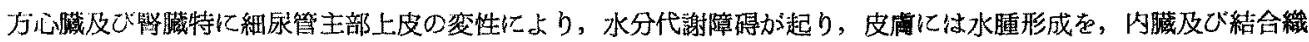

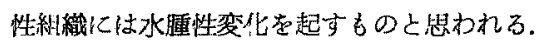

\section{結 論}

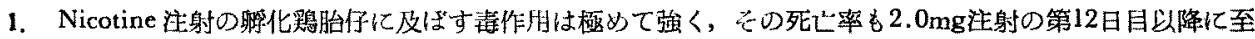

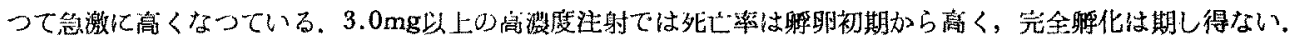

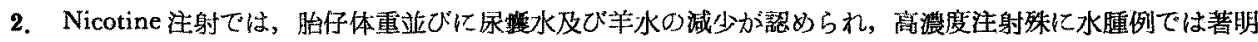

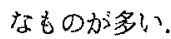

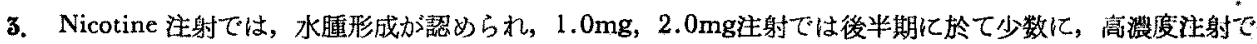

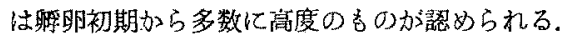

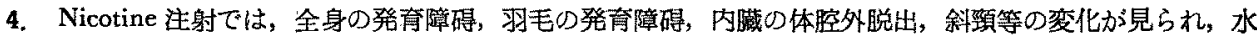
臨例ではこれ等の変化を合件している。

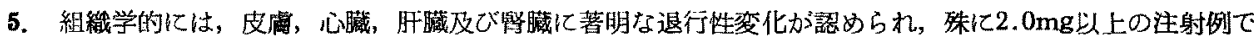
は, 空胞密性が極めて強く，各缄器には水腫性爱化が著明で，皮鹿には水腫形成が，体腔内には腔水症が認めら れる。

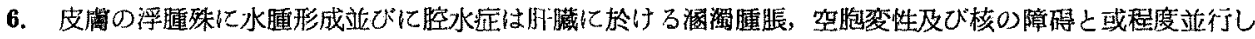
ているが，脂肪変性とは必ずしも主行しているとは云えない。

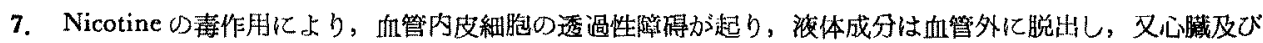

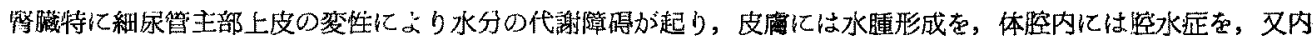
䁍及び結合織性組織には水腫性変化を起すものと思われる。

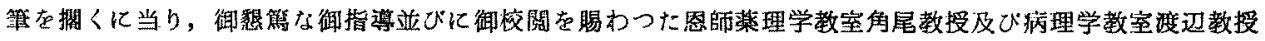

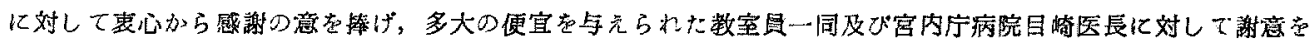
㧼する。

\section{引用些目}

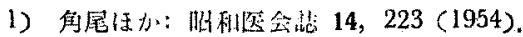

2)畨木: 同善 14, 246 (1954).

3) 牦尾はか: 甘染琵誌 51，1428(1955).

4) 䦛谷: 同誌 51，1858 (1955).

5) 医下: 同誌 51, 1868 (1955).

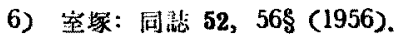


7) 日須望: 同誌 52，568 (1956).

8)角尾，室探はか：第79回，第81回ビタミン委圆会報告 (1955).

9）和田：炤和医会誌 12，179及び197 (1952).

10) 尾持: 家鵙発生学.

11) 村山: 解剖学雑蒜 15, 339 (1940).

12) L. W. Smith and E. S. Gaulze: Essentials of Pathology 21 (1942).

13) E. v. Gierke: Aschoffs Pathologische Anatomie, Allgemeiner Teil 579 (1913).

14) 若松：日病会誌 1,489 (1942).

\section{附録图説明}

皮漂本 ( $、$ ロリ一染色)

第 1 図、Nicotine 3.0mg注射 第 9 日目 $(6 \times 10)$ 水腫腔及び控内有形物䆓.

第 2 図. 対照 (無処置) 第18日目 $(6 \times 10)$.

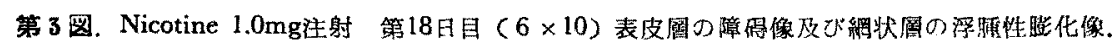

第 4 図. Nicotine $2.0 \mathrm{mg}$ 注射 第18日目著明水随例の算胞状形成.

第 5 图. 同上水腫居辺部 震胞壁及び腔内有形物資.

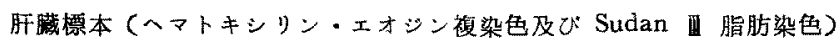

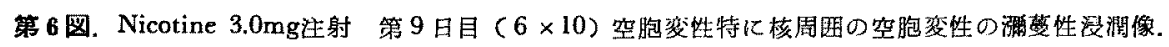

第 7 図. Nicotine $2.0 \mathrm{mg}$ 注射 第 15 日目 $(8 \times 10)$ 左半分は烄死像, 右半分は解離像.

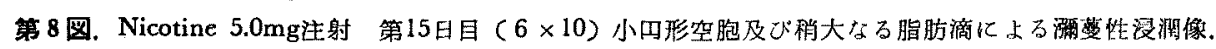

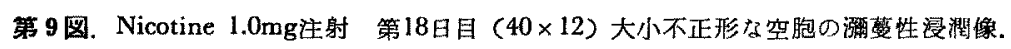

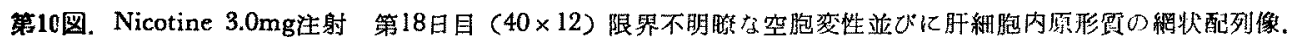

第11図. Nicotine $4.0 \mathrm{mg}$ 注射 第18日目 $(40 \times 12)$ 肝細胞全体に及空胞瓷性.

第12图. Nicotine 2.0mg注射 第18日目 $(40 \times 12) 11$ 図同様変化の脂肪染色. その他の臟器の標本(へマトキシリン・エネシン襍染色)

第13図. Nicotine $2.0 \mathrm{mg}$ 注射 第18日目 $(6 \times 10)$ 心外膜の水看性変化.

第14图, Nicotine 3.0mg拄射 第18日目 $(6 \times 10)$ 気慗内の有形物賈.

第15图, Nicotine $1.0 \mathrm{mg}$ 注射 第18日目 $(40 \times 12)$ 原腎の空胞変性及び管腔の閣鎖像。

策16図. Nicotine 3.0mg注射 第18日目 $(40 \times 12)$ 後腎の空胞变性及び管空の開銷像, 
木脇論文附錄図（其の 1）

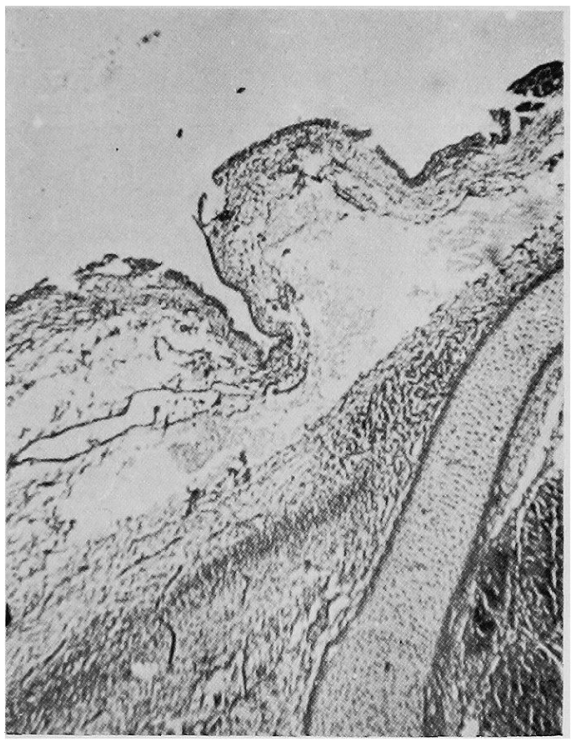

第 1 図

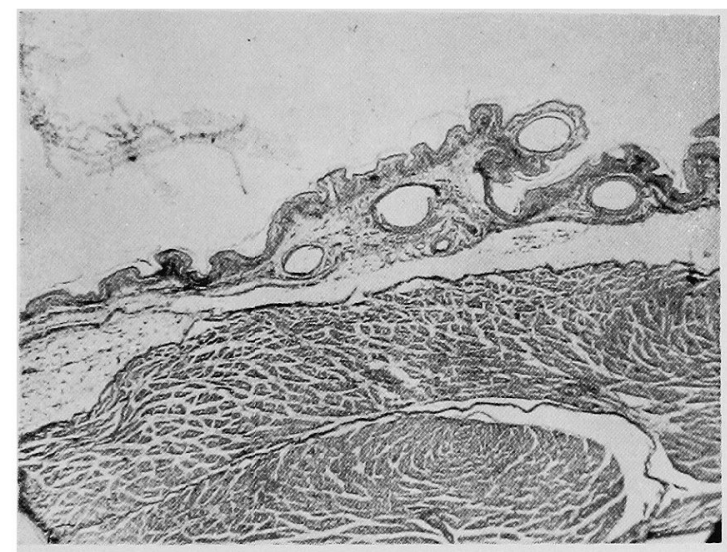

第 2 図

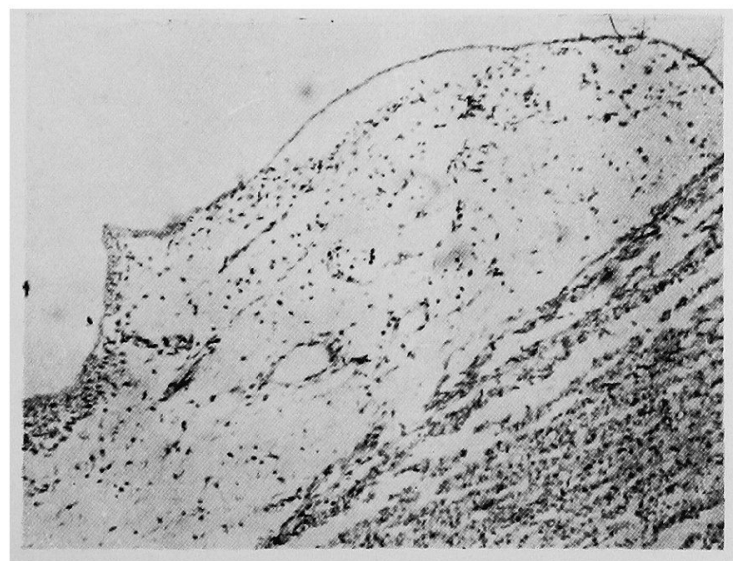

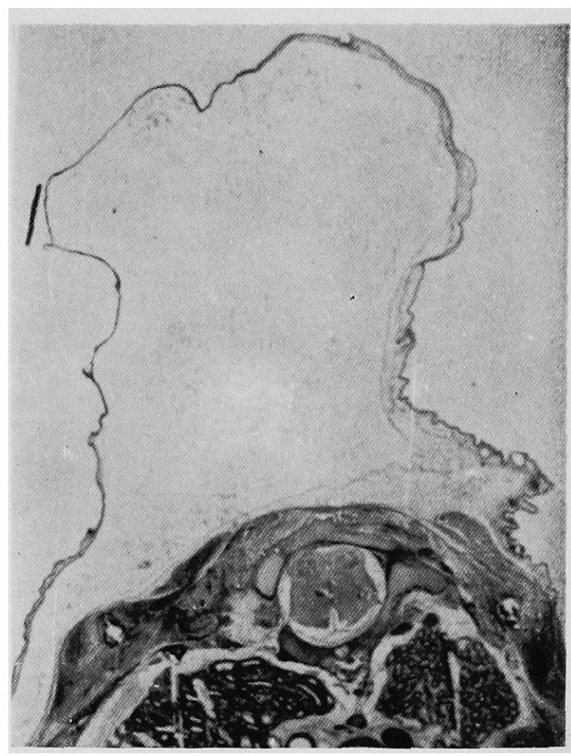

第 4 図

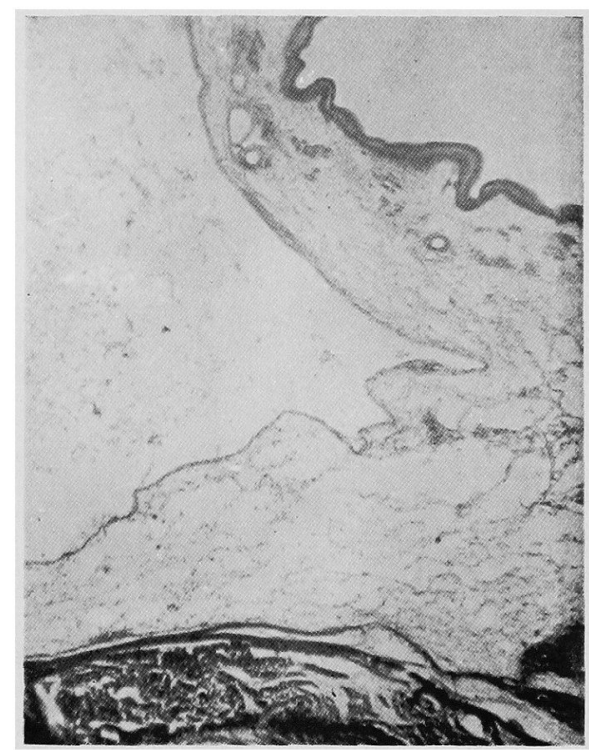

第 5 図 
木脇論文附錄図（其の 2)

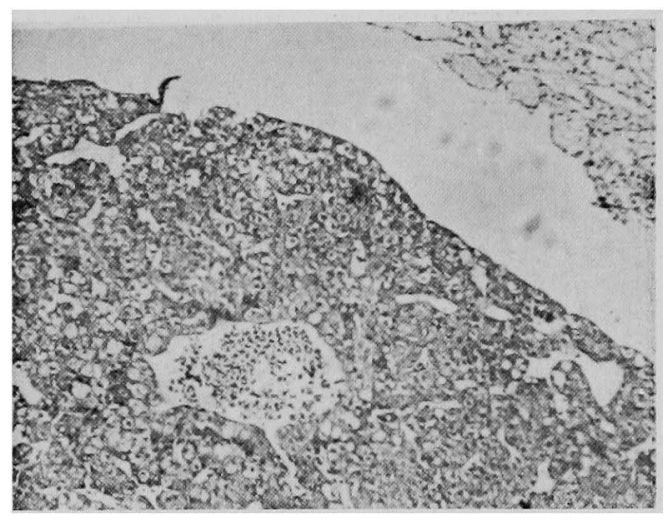

第 6 図

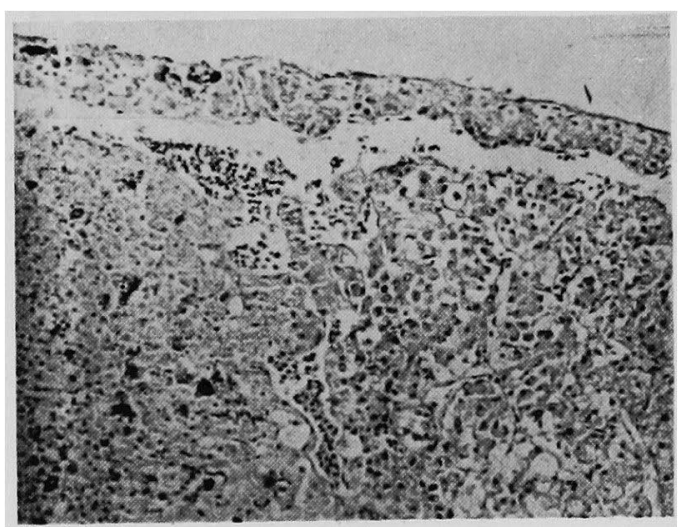

第 7 図

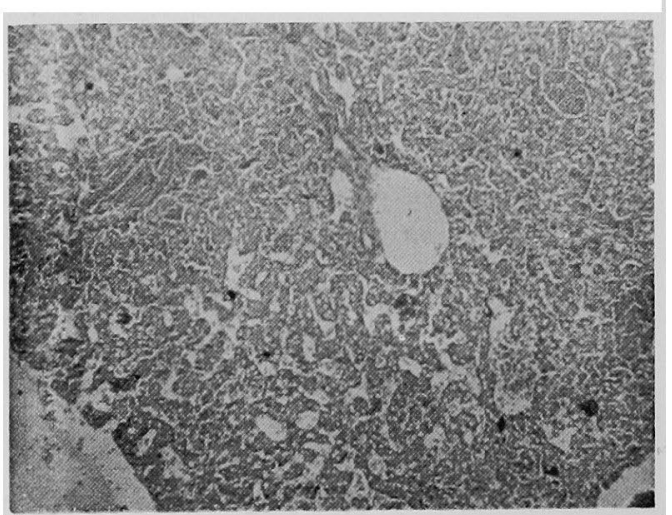

第 8 図

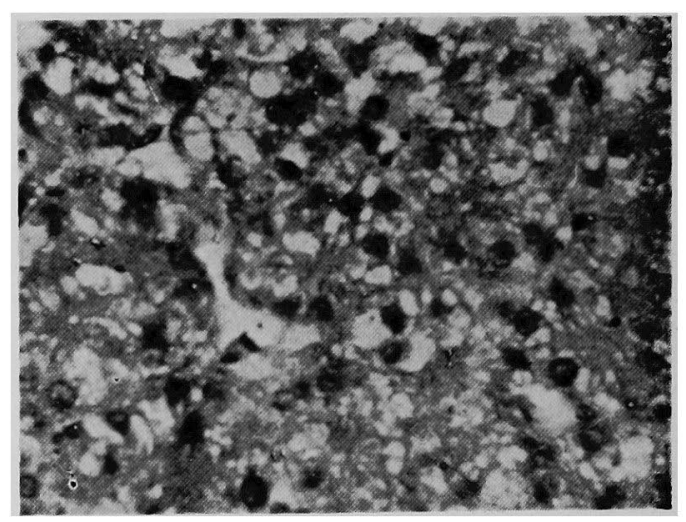

第 9 図

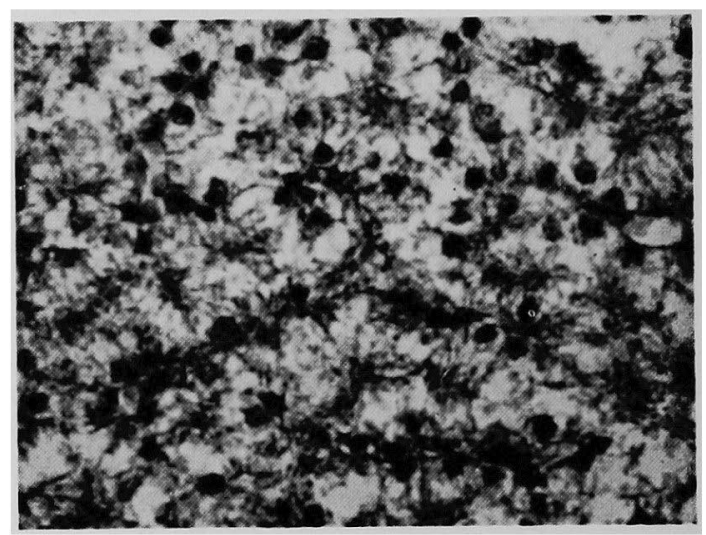

第 10 図

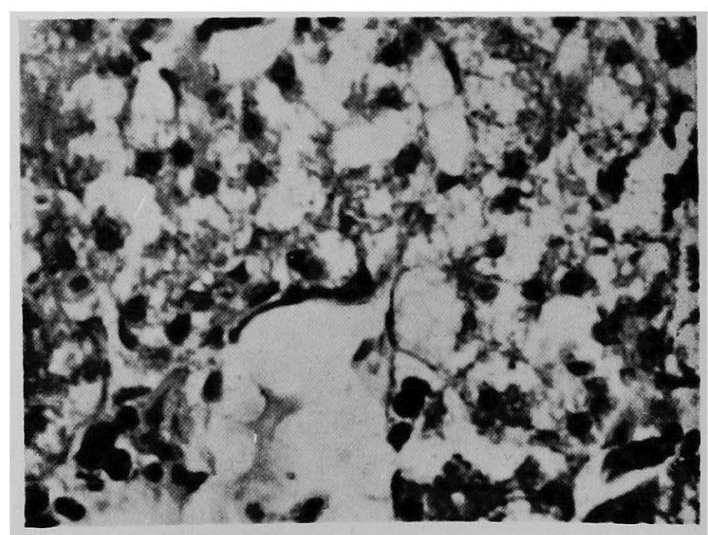

第 11 图 
木脇論文附錄図（其の3）

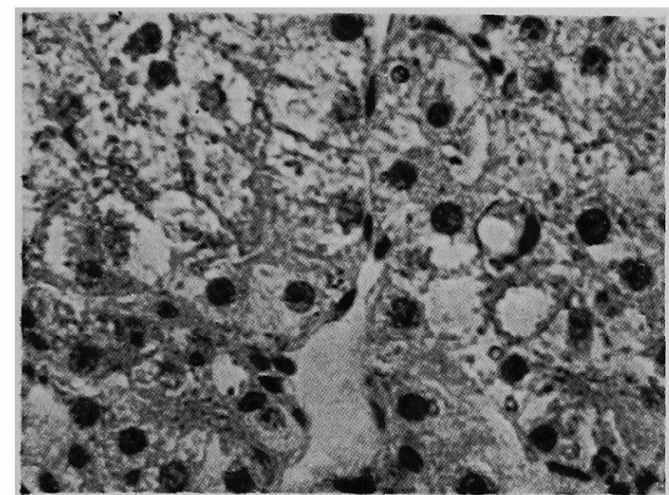

第 12 図

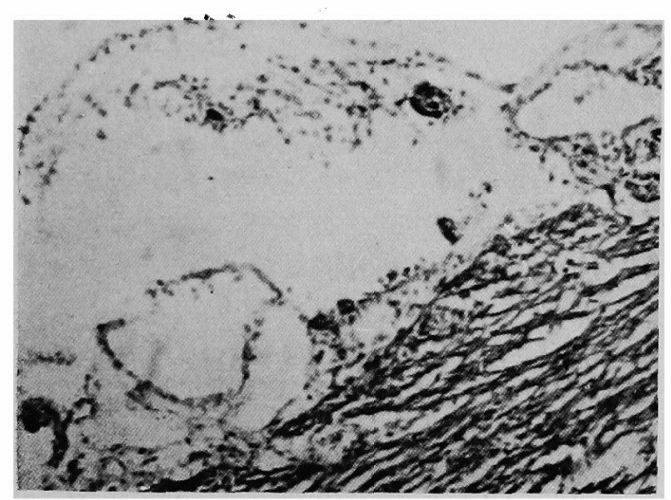

第 13 図

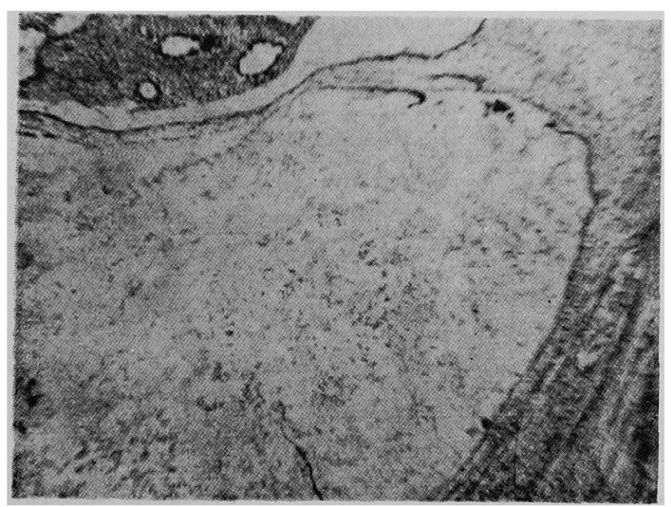

第 14 図

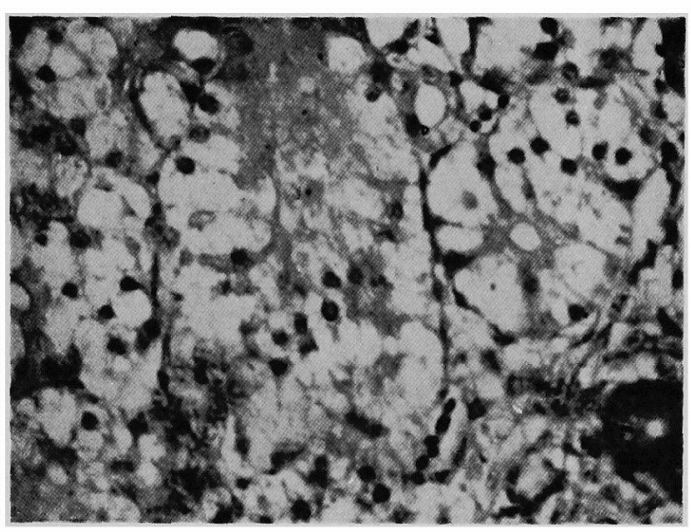

第 15 図

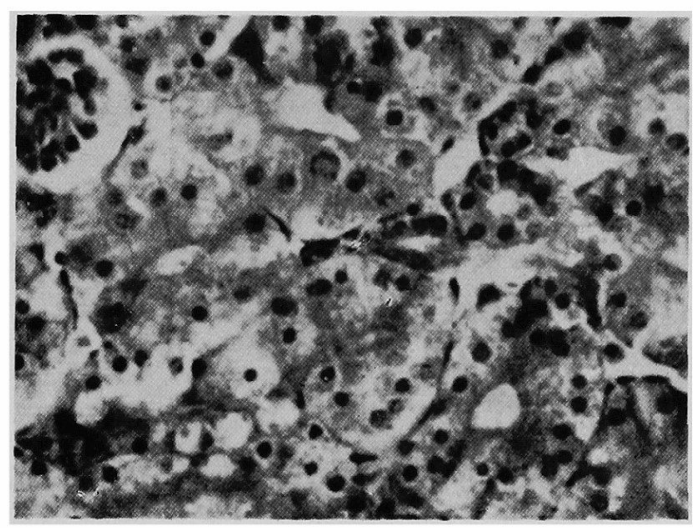

第 16 図 